UNIVERSIDADE DE SÃO PAULO

FACULDADE DE FILOSOFIA, LETRAS E CIÊNCIAS HUMANAS

DEPARTAMENTO DE TEORIA LITERÁRIA E LITERATURA COMPARADA

PROGRAMA DE PÓS-GRADUAÇÃO EM TEORIA LITERÁRIA E

LITERATURA COMPARADA

MARIANA RUGGIERI

\title{
VARIAÇÕES DA LITERATURA
}

VERSÃO CORRIGIDA

São Paulo

2017 


\title{
UNIVERSIDADE DE SÃO PAULO \\ FACULDADE DE FILOSOFIA, LETRAS E CIÊNCIAS HUMANAS \\ DEPARTAMENTO DE TEORIA LITERÁRIA E LITERATURA COMPARADA \\ PROGRAMA DE PÓS-GRADUAÇÃO EM TEORIA LITERÁRIA E \\ LITERATURA COMPARADA
}

\section{variações da literatura}

\begin{abstract}
Tese apresentada ao Programa de PósGraduação do Departamento de Teoria Literária e Literatura Comparada da Faculdade de Filosofia, Letras e Ciências Humanas da Universidade de São Paulo, para a obtenção do título de Doutora em Letras.
\end{abstract}

Orientador: Prof. Dr. Marcos Piason Natali

De acordo,

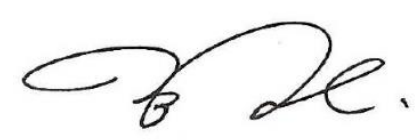

Versão Corrigida

São Paulo 
Autorizo a reprodução e divulgação total ou parcial deste trabalho, por qualquer meio convencional ou eletrônico, para fins de estudo e pesquisa, desde que citada a fonte.

Catalogação na Publicação

Serviço de Biblioteca e Documentação

Faculdade de Filosofia, Letras e Ciências Humanas da Universidade de São Paulo

RR931v

Ruggieri, Mariana

Variações da Literatura / Mariana Ruggieri ;

orientador Marcos Natali. - São Paulo, 2017.

$210 \mathrm{f}$.

Tese (Doutorado)- Faculdade de Filosofia, Letras e Ciências Humanas da Universidade de São Paulo. Departamento de Teoria Literária e Literatura

Comparada. Área de concentração: Teoria Literária e Literatura Comparada.

1. Animais. 2. Drones. 3. EZLN. 4. Feminicídios. 5. Hipnose. I. Natali, Marcos, orient. II. Título. 


\section{Folha de Aprovação}

Nome: RUGGIERI, Mariana

Título: Variações da literatura

Tese apresentada à Faculdade de Filosofia, Letras e Ciências Humanas da Universidade de São Paulo para obtenção do título de Doutora em Letras.

Aprovada em:

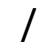

\section{Banca Examinadora}

Prof(a). Dr(a). Instituição:

Julgamento: Assinatura:

$\operatorname{Prof}(a) . \operatorname{Dr}(a)$. Instituição:

Julgamento: Assinatura:

Prof(a). Dr(a). Instituição:

Julgamento: Assinatura:

Prof(a). Dr(a). Instituição:

Julgamento: Assinatura:

Prof(a). Dr(a). Instituição:

Julgamento: Assinatura: 
ao vô Olavo, que deixou aos vivos flores vivas à vó Izabel, que tem cheiro de mar 
/agradecimentos\

para conversar sem rumo sobre patti smith: maria betânia amoroso para estender uma rede em algodoal: fabiana carneiro

para ir no fliperama matar zumbis: tomaz amorim

para considerar a possibilidade de ir pro japão: carmen e claudio ruggieri

para acreditar na possibilidade de costurar papel: rodrigo lobo

para qualquer coisa, a qualquer hora: william kenji bellete

para gargalhar abraçada e sonhar samambaias: pilar guimarães

para afundar na doçura de um texto: renato prelorentzou

para ir ver senhores lendo com lupas: biblioteca mário de andrade, apesar do charles cosac

para tomar um enquadro na praça da república: lucía naser

para tabelar e mandar pro gol: paulinha saes

para se descobrir tradutora: marcelo lotufo

para acompanhar de longe, no frio: raquel parrine

para cultivar jardins em sacadas: bruna de carvalho

para tomar uma água de coco no futuro: sofia nestrovski

para criar uma língua própria, professor pardal of my heart: enrico ruggieri

para devir matilha: carolina correia dos santos

para escrever poemas em casarões antigos: clarisse lyra

para querer tener de profesor de literatura para siempre: marcos natali

para deixar por último por não saber por onde, se pelos olhos ou pelas mãos, mas

principalmente por acordarmos todos os dias em casa: débora lima

* agradeço à Fundação de Amparo à Pesquisa do Estado de São Paulo (processo n 2013/23692-

5) pelo financiamento dessa pesquisa e também os funcionários do DTLLC por todo o apoio operacional nos últimos anos. 
RUGGIERI, M. Variações da literatura. 2017. Tese (Doutorado) - Faculdade de Filosofia, Letras e Ciências Humanas, Universidade de São Paulo, São Paulo.

\section{RESUMO}

Escrever uma tese sobre as variações da literatura é, em muitos sentidos, variar junto com ela, isto é, empreender um exercício de comparação entre a teoria literária e outras teorias. Neste espírito, o texto a seguir dedica-se à especulação em torno do funcionamento de algumas categorias da teoria literária - como autoria, referencialidade e iterabilidade - por meio da investigação de outros assuntos que em um primeiro momento não pareceriam pertencer à ordem do literário, como a hipnose, os drones, os feminicídios, entre outros. Com isso propõe-se tensionar os limites da literatura e da teoria literária, em especial aquela que se organiza ao redor das indagações sobre o sentido do sentido.

Palavras-chave: Animais, Drones, EZLN, Feminicídios, Hipnose 
RUGGIERI, M. Variations on literature. 2017. Tese (Doutorado) - Faculdade de Filosofia, Letras e Ciências Humanas, Universidade de São Paulo, São Paulo.

\section{ABSTRACT}

To write a thesis on the variations of literature is, in many ways, to vary with it, that is, to carry out the task of comparing literary theory to other theories. In this spirit, the following pages present speculations on the inner workings of some literary categories - such as authorship, referentiality and iterability - by means of an investigation of other subject matter that at first glance appear to have nothing to do with literature, such as hypnosis, drones and feminicides, among others. With this I propose to prod the limits of literature and literary theory, particularly that which organizes itself around questions regarding the meaning of meaning.

Key-words: Animals, Drones, EZLN, Feminicides, Hypnosis 
<variações da literatura >

só pra variar

(R. Seixas)

mecê tá doente, mecê tá variando...

(G. Rosa) 


\section{|sumário/}

introdução p.1

1. tentativa: junho p. 3 sonhos, uma segunda introdução p.20

2.1 hipnose p.36

2.2 drones p.49

2.3 radiação p.69

3. ezln p.88

4. feminicídios p.108

5. animais p.130

post scriptum - para isso continuamos vivas p.146 citações traduzidas p.168 bibliografia p.187 
/introdução\

Lo que aún no tiene forma me protegerá. Os monstros, sussurra Derrida, não podem ser anunciados. Não é possível dizer veja aqui este meu monstro sem transformá-lo em um animal doméstico de nome duvidoso. Moby Dick seeks thee not. It is thou, thou, that madly seekest him $!^{1} \mathrm{O}$ rastro do monstro, isso sim podemos anunciar, algo monstruoso no seu rastro, o irreconhecível, uma espécie inespecífica. Davi Kopenawa diz dos animais vistos na floresta que, em comparação aos seus espíritos, são feios e não passam de comida para humanos. Quanta tristeza em caçar em um zoológico - querer criar um bom deus para movimentos geológicos, escapando do acidente, da falha - mas sem também recair aqui em um elogio ao fracasso, que nada mais é do que avizinhar-se à noção de êxito, acordar em uma casa estranha sem lembrar como lá chegou. Blanchot conta uma história segundo a qual o messias se encontra nas portas de Roma entre os pedintes e os leprosos. Ao contrário do que se poderia esperar, ele não se disfarça para prevenir a sua volta, no entanto é, precisamente, reconhecido, facilmente identificável na multidão. Alguém, obcecado com a possibilidade de dirigir uma pergunta ao messias, indaga: Quando você vai voltar? Não há nenhuma garantia em sua presença, o seu estar lá, portanto, pouco tem a ver com o seu retorno. Tanto no futuro quanto no passado (afinal, afirma-se que ele já veio uma vez) a sua vinda não corresponde a nenhum tipo de presença. Sem a incerteza da sua vinda, não há messias, o que equivale a dizer que o messias é aquele que não sabemos quando vem - um bonde (um ônibus lotado?) chamado desejo. Diante da sua presença, a pergunta o reinsere no tempo incerto; nenhuma outra pergunta é possível ao messias que não o queira como

\footnotetext{
${ }^{1}$ As traduções correspondentes a todas as citações em inglês podem ser encontradas ao final do texto, a partir da página 168. A não ser que haja indicação, as traduções são minhas.
} 
senhor do fim dos tempos. Para Benjamin, isso quer dizer: somente para a humanidade redimida o passado é citável, em cada um dos seus momentos. Cada momento vivido transforma-se numa citation à l'ordre du jour - e esse dia é justamente o do juízo final. Antes, vou com Deleuze; todo delírio é histórico-mundial. Isso não terá sido uma tese, mas terá se referido a um outro cuja aparição passa ao largo de sua presença, de seu nome, de seu nariz sob os óculos que acolhem a minha imagem. A veces pienso que estoy viviendo en otra parte. 
\1. tentativa: junho/

a cultura e a civilização, elas que se danem ou não

(Gilberto Gil na voz de Gal Costa)

Escrevi duas versões do projeto de doutorado entre junho e novembro de 2013. Nesses meses revoltos, que se estenderam até meados de junho de 2014 , data do início da copa do mundo, parecia que o único gênero possível para um texto era o manifesto. Hay momentos para recitar poesías y hay momentos para boxear. Pensar - o exercício de pensar - não conseguia menos do que conjurar a alegria e a urgência de vivenciar a multidão, de reinventar-se como um nós, um nó, vários nós. Ainda assim, a comunidade surgiu como eixo central da pesquisa já um pouco desconfiada do alcance e da estabilidade dessa coisa comum que a constituiria. O povo tinha acordado e tinha coisas horríveis a dizer. Vallirana, que tenía un cuarto más amplio, sólo se encerró tres días, que pasó casi sin dormir, enganchado a la tele, siguiendo las manifestaciones y pensando. Cuando los tres días concluyeron subió a la azotea y se construyó un pequeño cartel. El cartel decía: "NO A LA GUERRA - VIVA SADAM HUSEIN". Se é verdade que o povo não antecede a insurreição, mas surge diante e em função dela, é de se esperar que um companheiro possa também, em outra situação, ser um inimigo. Cuando acabó de escribir subió a la azotea e hizo otra pancarta. Ésta decía: "NO A LA GUERRA - VIVA EL PUEBLO IRAKÍ - MUERAN LOS JUDÍOS". O povo era uma hidra, Ya no hay imágenes, Gaspar, ni metáforas en la zona./Policías, víctimas, putas armadas/con desecho militares, maricas,/árabes, vendedores de lotería,/feministas que escriben en sus habitaciones./La desesperanza. La furia./El atardecer. - ou como escreveu Victor Hugo 
sobre as outras Jornadas de Junho: se admitirmos que a gigantesa e teneborsa insurreição de junho fosse feita de cólera e de enigma, sentiríamos por trás da primeira barricada o dragão; por trás da segunda, a esfinge.

Em 2013 - no dia 2 de outubro - também houve uma marcha em São Paulo pela demarcação de terras indígenas em que alguns índios jogaram latas de tinta vermelha no Monumento às Bandeiras, erguendo de certa forma um novo monumento, reerguendo-o como o monumento ao genocídio que ele é y al mismo tiempo abarcar con una sola mirada/el escenario del crimen. Uma operação linguística, portanto, que inscreve outra significação no significante prévio, extraindo o que já estava lá escondido: o Monumento às Bandeiras não deixa de ser um monumento às bandeiras porque as bandeiras foram principalmente frentes de extermínio. No era Rimbaud, sólo era un niño indio. A tinta vermelha sobre a pedra torna-se, por conseguinte, índice visível daquilo que o monumento quer invisível, a pegada bárbara sobre os documentos da cultura. Há principalmente silêncio, algo que os surdos e alfaias dos nossos movimentos só conseguem traduzir como um ar fúnebre (ou um amigo, que me dizia: "isso aqui está parecendo coisa do John Cage"), mas nessa ausência de palavras, nessa fala tornada lacuna - talvez por cause dessa lacuna, que denuncia os mecanismos da fala -, existe uma linguagem potente.

Uma reintegração de posse de um edifício ocupado na Av. São João encontra resistência no dia 16 de setembro de 2014 . Um ônibus arde na manhã de uma terçafeira em frente ao Teatro Municipal e a tropa de choque varre as ruas e calçadões com bombas de gás, trazendo ao centro da cidade a violência sem destinatário preciso que 
caracteriza o estado policial na periferia. A repórter ao meu lado narra aos seus telespectadores um cenário ameaçador: um confronto entre uma horda de vândalos que devasta a cidade e uma polícia que está apenas cumprindo ordens judiciais. Fora do campo de visão da câmera, os manifestantes não são mais de trinta pessoas, entre moradores de rua, despejados e skatistas, que colocam fogo em algum saco de lixo e logo correm das bombas que são lançadas - uma criança me diz, orgulhosa, “olha lá, aquele policial ali, fui eu que lavei ele todo de tinta". Os policiais manchados de branco são poucos nos seus pelotões de robocops - que parecem ter vindo do futuro para reprimir - de modo que se torna bastante difícil não notar as desproporções que constituem o conflito noticiado. Qualquer semblante de igualdade entre as partes em disputa se desfaz na figura patética do policial sujo de tinta, armado até os dentes com seus brinquedos "não-letais"2, rodeado por colegas dispostos a vingar sua marca.

Outro monumento, agora em um filme de Karim Aïnouz, Viajo porque preciso, volto porque te amo, um monumento que existiu, mas será alagado pela transposição de um rio, por alguma barragem, dessas muitas barragens que se constroem no Brasil, na China ${ }^{3}$, na Malásia, um monumento em que se lê: "Hommenagem do povo do século XIX ao povo do século XX". Curiosamente, a inscrição anuncia o que é próprio a todo monumento, isto é, um testamento ao futuro, uma tentativa de garantir que o (um?)

\footnotetext{
${ }^{2}$ É verdade que longe do centro as balas são de verdade, mas durante os protestos de junho houve mortes em função de inalação de gás lacrimogêneo e queda de um viaduto cercado e atacado pela polícia.

${ }^{3}$ Otília Arantes: Chaina, na pronúncia em inglês do nome deste país que parece ameaçar finalmente a liderança secular dos Estados Unidos, ao se reconstruir numa velocidade sem precedentes. Mas também Chai-na, em mandarim, que é "demolir aí". Uma composição irônica adotada pelos opositores à atual política chinesa de terra arrasada, com os ideogramas que correspondem ao carimbo governamental "demolir" - nos edifícios a serem evacuados e destruídos, sem qualquer tipo de apelação, acrescido da partícula designativa - "ai" - a apontar o próximo entulho. Ver também Still Life, filme de Jia Zhang Ke, entre outras coisas, sobre a construção das Três Gargantas.
} 
presente, quando for passado, exista ainda no futuro. A homenagem do povo do século XIX ao povo do século XX é singela - não mais do que um veículo entre tempos, aparentemente sem nenhuma narrativa de vitória ou grandeza atrelada a ela -, mas é principalmente profética, pois sabe que o seu futuro, a sua sobrevida, é reduzida e não chegará a ver o povo do século XXI. O povo do século XX, por sua vez, ou recusa a homenagem ou a retribui da forma que sabe: colocando algo novo no lugar. Lévi-Strauss ou Caetano Veloso: aqui tudo parece que era ainda construção mas já é ruína.

Em jogo nessas operações de sobrecodificação está a possibilidade de reconstituir a cena do crime, mais interessante, talvez, do que a destruição - o derrubar das estátuas que caracteriza a queda de muitos regimes - ou a substituição por uma outra versão da história. Incidir sobre algo de forma a desentranhar a sua tensão constitutiva, inscrever nele - deixar aparente - a diferenciação interna que o caracteriza. Dejar un libro de geometría colgado a la intemperie para ver si aprende cuatro cosas de la vida real. O assunto aqui também é a literatura - a possibilidade de sobrecodificá-la - e é possível imaginar muitas formas de fazer isso: erasure poetry; o Boycott Project de Vanessa Place, em que textos canônicos da teoria e crítica feministas têm sua escrita modificada, eliminando todas as referências ao feminino, substituindo-as pelo masculino, evidenciando a cumplicidade entre a desconstrução e a reafirmação do gênero em muitos desses escritos; El Aleph Engordado, de Pablo Katchadjian, que adicionou às 4000 palavras do El Aleph de Borges outras 5600, e foi subsequentemente processado por plágio. 
Lo bueno de robar libros (y no cajas fuertes) es que uno puede examinar con detenimiento su contenido antes de perpetrar el delito. Me interessa algo sobre a literatura, a preposição levada a sério em seus termos, de modo que não haja nada a decodificar. Distante, portanto, do tanatoscópio, el mundo está vivo y nada vivo tiene remedio y ésa es nuestra suerte. Escrever sobre algo, no sentido de que algo se oferece para que possa ser sobre-escrito. Lo más importante del mundo era leer y viajar, tal vez la misma cosa, sin detenerse nunca. Há uma diferença entre o livro e a literatura, no sentido de que a literatura não necessariamente depende do suporte do livro, sendo a leitura e a escrita o seu veículo principal, a escrita inclusive como leitura e a leitura como escrita. Al cabo de las lecturas los escritores salían del alma de las piedras, que era donde vivían después de muertos, y se instalaban en el alma de los lectores como en una prisión mullida, pero que después esa prisión se ensanchaba o explotaba. O texto que agora escrevo pretende sobrecodificar escrituras cuja assinatura não me pertence, sobrecodificando, inclusive, a assinatura, que permanecerá como lacuna, fantasma convocado por outros feitiços que não o seu nome. Fugindo do perigo de incorrer em crime de plágio, deixarei indicadas em itálico essa língua e linguagem estrangeira, cujas palavras não são minhas (mas quais, realmente, seriam?). Por um lado, o itálico e a opção pela língua original certamente anulam a brincadeira interessante que poderia ser deixada aos leitores: quem escreveu o quê? Por outro lado, o tecido visivelmente heterogêneo permitirá refletir acerca da reciprocidade do corpo estranho: a literatura estranha a tese ou a tese estranha a literatura? Afinal, quem é hospedeiro e quem é o hóspede? No era más cómodo leer que escribir. 
A data que assinalei como um possível fim ao momento de insurreições - o início da Copa do Mundo - é imprecisa, como qualquer data que marca o início ou o término de um processo difuso. Certamente, porém, a Lei Geral da Copa forçou rapidamente um retorno à "normalidade" e o recrudescimento da segurança, que, como sabemos, geralmente tem muito pouco a ver com segurança e mais a ver com o cerceamento das possibilidades de manifestação. Tenía frío y tenía miedo, patrón, pero comprendí / que los Estadios, los compartimentos estancos, / marchaban de cabeza rumbo al pasado. / Todo lo que un día poseímos o quisimos poseer / marchaba de cabeza rumbo al pasado. Antes ainda do dia 12 de junho, no dia 06 de fevereiro de 2014 um cinegrafista da Band é morto, atingido por um rojão, durante a cobertura de uma manifestação no Rio de Janeiro contra a copa. Uma tragédia, sem dúvida, não obstante as circunstâncias ao redor de sua morte permanecerem até o momento pouco evidentes (sem contar que a espetacularização do óbito reafirma que nem todas a mortes têm o mesmo valor na economia da vida), e foi justamente em função dessa ausência de clareza que foi possível consolidar na opinião pública o que já estava em construção desde Junho de 2013: a separação entre os bons manifestantes e os maus manifestantes. De um lado os polinizadores da democracia, gente pacífica, educada; do outro lado vândalos, black blocs, delinquentes: as manifestações começavam pacíficas, mas eram sempre, segundo o discurso oficial, desvirtuadas por uma "minoria violenta". Em 2014 tornou-se normal manifestar-se dentro de um cordão de isolamento da tropa de choque, em que o número de policiais era por vezes o dobro do número de manifestantes. No dia 22 de fevereiro, 120 pessoas foram presas em São Paulo de uma só vez sem nenhum motivo aparente por meio de um método conhecido como kettling, aos que não foram fagocitados pela polícia, restaram as bombas e as balas de borracha de sempre. 
Diferente do que ocorrera no dia 13 de junho de 2013, ninguém mais parecia se importar em denunciar e condenar a violência policial - a divisão entre bons e maus manifestantes servia principalmente para justificar todos os métodos de repressão, pois o que estava sendo reprimido, segundo essa lógica, não era o direito democrático à manifestação, mas algo que, justamente, colocava a democracia em risco. Durante palestra a cadetes e oficiais na Academia de Polícia Militar do Rio de Janeiro, segundo o jornal Folha de São Paulo, Marilena Chauí defendeu que os black blocs teriam inclinações fascistas e que não se utilizariam do que ela chama de violência revolucionária, pois esta só se realizaria na presença de agentes que têm uma visão do que é inaceitável no presente e qual a institucionalidade futura que se pretende construir ${ }^{4}$. As placas no metrô de São Paulo avisam: DEIXE A ESQUERDA LIVRE.

Sei que não vou conseguir escapar à pergunta. Qual a sua tese? Não vou confessar. Não reconheço a lei desde onde essa pergunta se formula. Se há alguma linha à qual é preciso se subordinar para escrever este texto, que seja a tangente: a escrita da tese como uma máquina geradora de linhas de fuga, como si los personajes de Arcimboldi, acabado el libro, saltaran literalmente de la última página y siguieran huyendo. À esquerda e à direita as perguntas eram as mesmas: o que querem esses que se manifestam? qual o seu projeto? o seu programa? suas demandas? São sempre acusações em forma de perguntas: se não há um programa com diretrizes claras a serem implementadas, se não têm a solução definitiva, se não querem nada além de afirmar

\footnotetext{
${ }^{4}$ [Nota de 19/11/2017] Creio que é preciso alguma cautela na leitura desse trecho, por dois motivos. Primeiro porque circulou informalmente o relato de que em uma palestra Marilena Chauí teria dito que a Folha de S. Paulo havia distorcido a sua fala. Segundo porque não pretendo com isso invalidar todo a obra de Marilena Chauí, como se fez à época.
} 
sua voz e presença na rua, não são mais do que arruaceiros. Um programa político não pode anteceder a mobilização das pessoas; uma tese não pode anteceder a escrita - e ainda assim é possível que aqui também não surja nada parecido a um programa, nada parecido a uma tese.

Que coisa nomeia Junho? Uma data e um período no tempo, é certo, na ausência de algo mais preciso. Houve quem tentasse especificá-lo - Revolta do Vinagre, Revolta da Tarifa, Revolta dos Centavos - mas nenhum nome nomearia suficientemente o referente desse evento, desses eventos que foram Junho. Junho nomeia principalmente o fato de que não existem sentidos ou conceitos disponíveis para nomear essa coisa que conseguimos intuir e recontar, inclusive, de acordo com uma narrativa que se tornou mais ou menos protocolar sobre esses dias, semanas ou meses (a depender de quanto tempo se insistiu sobre o direito de permanecer nas ruas), mas a qual não parece se encontrar na esfera de uma linguagem plausível. Falar sobre Junho, enunciando Junho, conjurando Junho, repetindo mecanicamente uma data, uma série de datas-nomes sequenciais, 13 de Junho, 17 de Junho, 19 de Junho, de modo a nos enganar, a nos fazer pensar que estamos mais próximos à coisa em questão. Essa aproximação repetitiva, ao contrário, alarga a distância entre o que se diz daquilo que se diz e enfraquece, circunscreve a uma duração específica, tabula sobre uma linha de tempo (e muda-se a escala conforme convém: irrisório ou sem precedentes), cristaliza nas palavras-imagens dos posts de Facebook e vídeos no Youtube. Hoje, 25 de agosto de 2015, Rafael Braga Vieira continua preso por porte de Pinho Sol. 
Não se pode repetir Junho, ao contrário do que diziam os gritos do movimento estudantil nos protestos contra novo aumento da tarifa em São Paulo, no início de 2015. O acontecimento não se reproduz, pois o que o caracteriza é a abertura ao desconhecido - um evento cuja força não pode mais do que anunciar o desconhecimento sobre o que vem a seguir. Passadas as eleições presidenciais - dispositivo político onde o que parece estar em jogo é dar corda ao boneco exausto da democracia representativa e a manutenção da monocultura política - e o crescente acirramento da polarização entre governo e oposição, cujo aspecto mais atroz seja talvez a neutralização da parcela da esquerda que nunca quis o poder, parece haver a sensação - quase um consenso - de que a potência de fissurar os protocolos referentes a governar e ser governado está soterrada e asfixiada debaixo dos escombros da política institucional. Que la amnesia nunca nos bese en la boca, que nunca nos bese. Soñábamos con utopía y nos despertamos gritando. No entanto, dado que o que se pretende avançar neste texto é a comunidade como aquilo que se configura mais além da instituição, caracterizada pelo seu poder de destituição - não de um indivíduo específico que por contagem de votos ocupa um cargo, mas de um modo de operação que faz perpetuar a dinâmica simultânea de inclusão e exclusão - talvez seja necessário pensar se é possível habitar outro lugar que não a resistência. Resistir não é apenas reagir, não significa viver apenas em função de seu oposto, como um espelho ou um suplemento secundário. A resistência é o modo de existência do povo por vir, cuja maior força é imaginar, apesar dos fatos, uma outra forma de viver. A tarefa do texto que segue é encontrar a justa medida entre a carta de amor e a carta de despedida. De Latinoamérica: / Un hinterland de espectros y fantasmas. Há pouco a ser feito que não seja especular: receber e projetar espectros. 
Fantasmas que todos poseemos Simplemente / aguardando a alguien o algo sobre las

ruinas. Não podemos repetir Junho, mas há algo sobre Junho que podemos herdar.

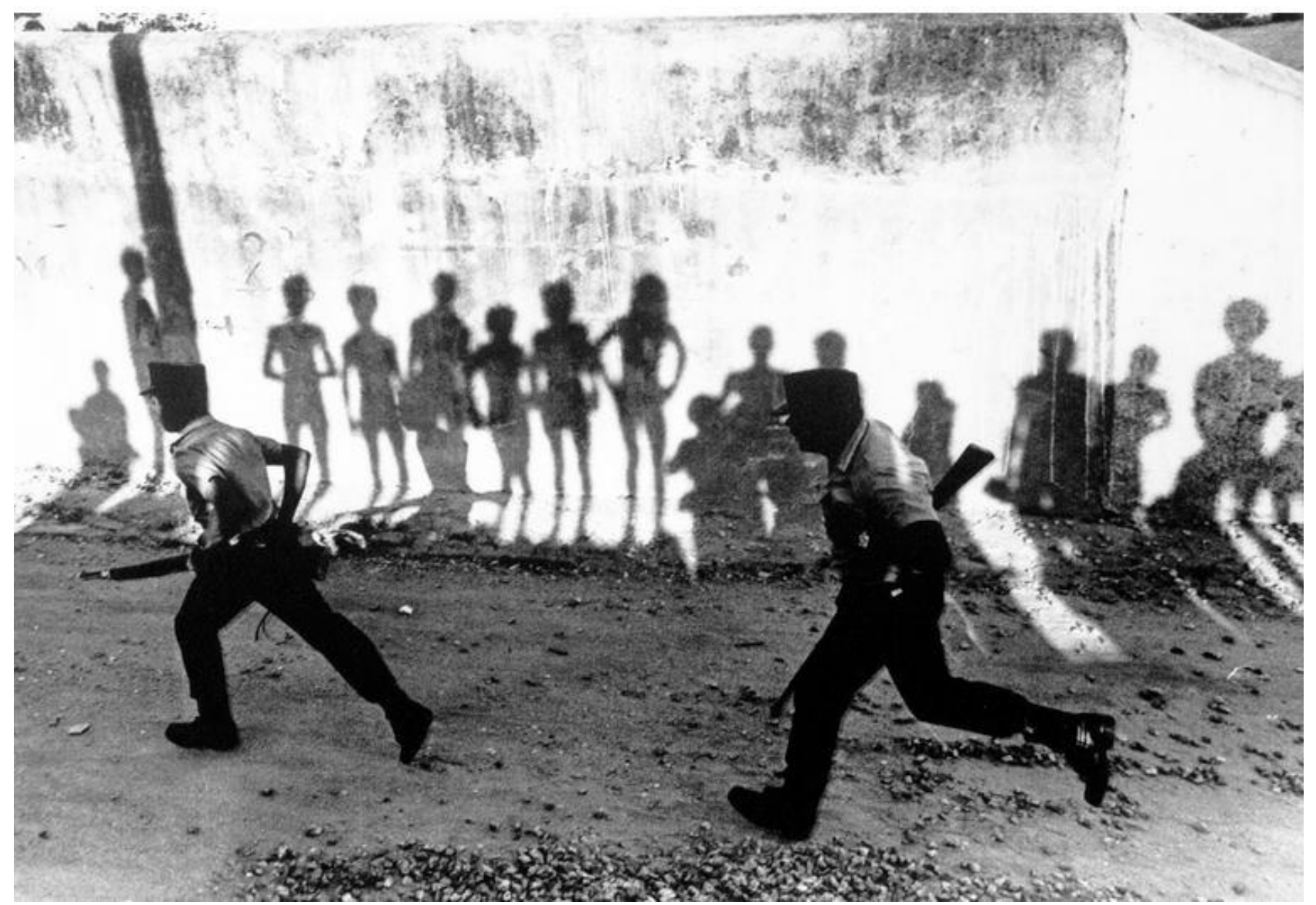

Foto: Walter Firmo, 1977

Possível legenda: Democracy - the disruptive, ruinous appearance or mournful arrival of the demos. G. Williams

[e ainda nem comecei a falar sobre como o mundo dos animais, que é também o nosso mundo - um "nosso" possessivo que pouco tem a ver com propriedade porque nós somos do mundo - fica a cada dia mais silencioso. o último rinoceronte branco macho do mundo vive - e nada mais urgente do que duvidar desse verbo - sob a proteção armada de militares.] 
O manifesto é um gênero cuja destinação final é uma intervenção no curso da história. No entanto, isto quer dizer que o manifesto é um gênero que também constrói a sua própria história. Em Poetry of the Revolution: Marx, Manifestos, and the AvantGardes, Martin Puchner rastreia as versões para o Manifesto Comunista. Escrito durante as revoluções de 1848 , e tendo que deparar-se com o fato de que o futuro previsto não havia se realizado, o Manifesto Comunista dá origem a uma série de atualizações futuras, com prefácios cada vez mais longos. Por um lado, Marx e Engels querem fixá-lo no tempo de modo a preservar seu gesto fundacional - a da criação de um proletariado que não se constituía ainda como classe para si mesma -, por outro, ambos compreendem a necessidade de se manter em sintonia com a história da industrialização, seu percurso no tempo e espaço, que é, também, pela lógica do próprio manifesto, a história do proletariado. Cada atualização, entretanto, age justamente para desvelar a falência, ou o adiamento de um futuro antevisto, da revolução, do mundo por vir, isto é, de qualquer coisa que não a reação.

Hoje, dia 2 de novembro de 2017, Dia de Finados. Supostamente há na atmosfera fantasmas em trânsito. Espectros rondam a terra. Rafael Braga continua preso ${ }^{5}$. Estou chegando ao fim da tese e retorno ao ponto em que ela começou. Em algum momento decidi que não seria possível continuar por este caminho. Essas páginas por quais passamos deixaram de ser um começo conforme fui percebendo que seria impossível

\footnotetext{
${ }^{5}$ Em outubro de 2014, foi concedido à Rafael Braga o cumprimento de sua pena em regime semiaberto. Um mês depois, após um de seus advogados postar uma foto de Rafael em frente a uma pixação que dizia Você só olha da esquerda p/direita, o Estado te esmaga de cima p/ baixo, ele perdeu o direito ao regime aberto e passou um mês na solitária. Transcorridos alguns meses, passou ao regime aberto. De volta à casa de sua família, foi abordado por policiais da UPP, que forjaram um flagrante de apreensão de drogas. Rafael Braga foi condenado, dessa vez, por tráfico e associação ao tráfico. Na prisão contraiu tuberculose e em setembro de 2017 foi concedido a ele prisão domiciliar pelo tempo de seis meses para tratamento da doença.
} 
continuar alimentando o texto em função da ordem dos dias, dificuldade colocada não apenas pela questão quantitativa dos eventos, mas também, principalmente, pelos rumos de tais eventos, que se naquele momento já pareciam ruins, depois ficaram ainda muito piores. Mas se decido deixá-las - as páginas - aqui também como começo, ainda que na condição de uma espécie de rascunho, é porque creio que há algo do seu gesto que pode e deve ser conservado.

Alain Badiou, em A hipótese comunista, defende a atualidade, ainda hoje, da palavra comunismo e o faz por meio da investigação das relações entre a noção de falência e a noção de história. A inscrição histórica daquilo que é convocado politicamente nada mais é do que a sua inscrição histórica em seu próprio obstáculo. Qualquer teoria que não leve em consideração que desse encontro entre desejo e obstáculo podem derivar consequências inimagináveis aproxima-se de outras teorias, as quais muitas vezes fundamentaram expurgos e constituições puristas daquilo que deveria legislar sobre a vida em comum. Diz Badiou: o pensamento dos fracassos situase no ponto em que uma política comparece, inclusive a seus próprios olhos, diante do tribunal da História, tal como a hipótese comunista representa e imagina sua consistência. Seguindo o seu raciocínio, escrito desde a perspectiva de alguém que se considera herdeiro legítimo de Marx, de alguém que é sobretudo leitor de Marx, de que o comunismo deve ser compreendido principalmente como a inauguração de uma certa concepção de história - e, de fato, o Manifesto Comunista se apresenta também como o texto que não se reduz a expor a história das revoluções, mas justamente a história como revolução -, a própria noção de falência estaria à disposição (e, na verdade, bastante carente) de uma releitura. 
Na terceira parte do livro, retomando a Comuna de Paris, isto é, os dias de experiência coletiva e autônoma que seguiram entre março e maio de 1871, Badiou nos refere a um texto em que Marx avalia a inserção da Comuna na questão do Estado para questionar aquilo que ele - Badiou - chama de "críticas" persistentes, que depois se tornaram lugar-comum: o que faltou à Comuna foi capacidade de decisão. ${ }^{6} \mathrm{O}$ balanço de Marx, diz o filósofo fancês, é bastante ambíguo: por um lado, ele elogia tudo que lhe parece ir ao encontro da dissolução do Estado e, mais precisamente, do Estado-nação. Mas, por outro lado, ele lamenta incapacidades que são, na verdade, incapacidades do Estado: a fraqueza da centralização militar, a impossibilidade de definir prioridades financeiras, ou ainda a imperícia no que diz respeito à questão nacional, na maneira de se dirigir às outras cidades, no que é dito ou não sobre a guerra com a Prússia, ou no que se refere à adesão da massa rural. Badiou insiste que todas essas eram questões para as quais a Comuna não possuía nem meios de resposta nem de consideração, sua força existia em outra parte, mas que é sintomático que tais leituras fossem desembocar na forma política supostamente mais perfeita, a do partido-Estado. Resta perguntar se, dando uma solução aos problemas de Estado que a Comuna não conseguiu resolver, o partido-Estado não suprimiu muitos dos problemas políticos que a Comuna teve o mérito

\footnotetext{
${ }^{6}$ O Comitê Invisível, de inclinação anarquista, também parece chegar a conclusão similar sobre os nossos próprios tempos, o que parece sugerir que a leitura pelo viés da derrota como resultado da ausência de um projeto não pertence exclusivamente a uma única corrente política. O seu primeiro manifesto, $A$ insurreição que vem, de 2007, afirma que ninguém pode honestamente negar a força do ataque que não formula qualquer reivindicação, qualquer mensagem a não ser a da ameaça; que não quer saber da política para nada. É preciso ser cego para não ver tudo o que há de puramente político nesta negação resoluta da política; ou então não ter qualquer conhecimento dos movimentos autônomos da juventude dos últimos trinta anos. Já o seu segundo manifesto, Aos nossos amigos, lançado em 2014, apresenta uma escalada no tom que, entre o rancor daquilo que nomeia insistentemente como a derrota do ciclo de insurreições entre 2008-2014 e a necessidade de refundar a sua autoridade, afirma que o que o caso grego nos ensina é que sem uma ideia substancial do que seria uma vitória, apenas podemos ser vencidos. $A$ determinação insurrecional não basta por si só; a nossa confusão ainda é demasiado espessa. Que o estudo das nossas derrotas nos sirva, pelo menos, para a dissipar um pouco. Lucas Legume, um dos rostos mais conhecidos do MPL em 2013, também escreveu avaliação similar em 04/08/2015, no texto "O Movimento Passe Livre acabou?".
} 
de vislumbrar. Para Badiou, a Comuna constitui um evento, no sentido forte do termo, porque ela não simplesmente levou a cabo a realização de um possível, mas verdadeiramente criou um possível. Tal evento só é possível na medida em que se subtrai do estado. A ideia comunista, para ele, portanto, resume-se a situar-se em um local além ou aquém do estado (e nesse sentido aproxima-se muito à ideia anarquista): a hipótese comunista não diz (isso seria submeter o processo de verdade às leis do Estado) que o evento e suas consequências políticas organizadas são redutíveis a fatos. Mas também não diz que os fatos são inaptos a qualquer transcrição (para jogar com as palavras, como faz Lacan) histórica dos caráteres típicos de uma verdade. O comunismo de Badiou, ainda que não abra mão de uma Ideia com i maiúsculo, de um projeto que se quer realizar, procura manter viva a convicção de que todo evento é uma surpresa. Se não fosse, seria previsível como fato e, consequentemente, se inseriria na história do Estado, o que é contraditório.

Deixo essas páginas aqui também, portanto, para manter registrada uma contraposição a uma narrativa específica sobre as mobilizações de Junho, segundo a qual elas teriam atuado como força originária e unidirecional do processo que resultou no impeachment. Evidentemente há fortes indícios para apontar tal relação, principalmente se o ponto de vista levar em conta apenas as conjunturas da política institucional, no entanto isso é só porque as mobilizações de Junho ousaram ir de encontro aos seus obstáculos, de encontro a correlações de força que já estavam postas em movimento e não hesitaram em tomar uma decisão. É característico da reação não hesitar. Badiou considera a Comuna de Paris mais importante que, por exemplo, o 4 de setembro de 1870, quando cai o regime político do Segundo Império e começa a Terceira República. Ambas, ele diz, foram encabeçadas pela classe operária. A Comuna é uma 
insurreição que não inicia uma duração enquanto o 4 de setembro é um dia que muda o Estado, mas o 4 de setembro, de acordo com o filósofo, foi confiscado pela lógica estatal ao passo que a Comuna fez aparecer no mundo algo que até então não existia. Tal pensamento, ao contrário do que Badiou nos quer fazer crer, não pode ser reduzido ao comunismo, não é exclusiva ao que se entende regularmente como comunismo, mas, por outro lado, se for essa a herança do comunismo, por que não chamá-la assim? Sobre a possibilidade de medir as consequências e os efeitos de um acontecimento político no intuito de calcular seu êxito ou sua derrota, Badiou diz que é pelo que se prolonga dela [da insurreição] na concentração - fora dela mesma - de sua intensidade, que se pode julgar se uma adjunção aleatória no mundo merece ser mantida não só, afora as continuações e os fatos, no caso de uma singularidade, mas sobretudo no caso de um evento. De modo resumido, isso equivale a dizer que: os começos são medidos por aquilo que eles autorizam como recomeços.

Em algum momento do processo de escrita também percebi, à revelia das minhas próprias afirmações, que muito provavelmente o texto aqui presente tratava-se de uma tese, sem que para isso tivesse sido necessário passar pelo confessionário. Isso necessariamente tornou o tom empregado nesta parte intitulada tentativa: junho irreconhecível. ${ }^{7} \mathrm{O}$ tom do manifesto, um gênero textual que necessariamente funda sua autoridade por meio da linguagem, diferindo-se assim de um decreto ou de uma revelação, onde a autoridade antecede o texto, exprime muito pouco além da sua urgência e da sua impaciência, como diz Puchner, consigo mesmo. Essa impaciência

\footnotetext{
${ }^{7}$ Blanchot, em um texto chamado "Marx's Three Voices", fala sobre a diferenciação interna à escrita de Marx. Essa disjunção faz com que ele tenha que conviver entre vozes heterogênas e intraduzíveis, coisa, que segundo Blanchot, Marx não faz muito bem, dando origem a um leitor que deve submeter-se a uma reorganização sem fim.
} 
resulta em saber que, mesmo sem desconsiderar as teorias performativas da linguagem, há uma disjunção entre fala e ato que coloca o manifesto sempre em risco. Ainda falando sobre o Manifesto Comunista, o autor sugere que o Manifesto wants to create the context that will have ensured that its speech acts had been properly authorized by an authorizing context. The speech acts of the manifesto thus are launched in the anterior future, claiming that their authority will have been provided by the changes they themselves want to bring about. Tanto que a primeira versão do Manifesto Comunista circulou como se fosse produto das massas mobilizadas nas revoluções de 1848 , sem nenhuma menção aos nomes de Marx e Engels - como se o proletariado já existisse enquanto tal, quando na verdade o Manifesto estava justamente tentando, nos seus termos, constituí-lo. Talvez em função dessa tensão com a autoridade e a necessidade de um futuro que confirme a sua passagem de uma virtualidade à atualidade, o manifesto é um gênero para o qual também não há possibilidade de hesitação. A tese passou a existir somente no momento em que a hesitação se proliferou e passou a constituir o texto, isto é, quando a sua própria autoridade passou a ser também parte da questão.

Dois versos dizem:

la revolución se llama Atlántida y es feroz e infinita

Porém, logo em seguida, outro:

mas no sirve para nada 
a caminar, entonces, latinoamericanos

a caminar a caminar 
/sonhos, uma segunda introdução|

Si un hombre atravesara el Paraíso en un sueño, y le dieran una flor como prueba de que había estado ahí, y si al despertar encontrara esa flor en su mano... ¿entonces, qué? (Coleridge em um livro de Borges)

Qual é o sentido disso? é a pergunta literária, por excelência. Talvez seja essa também a pergunta realizada por todos que se encontram às voltas com a escrita de sua tese, em algum momento, com maior ou menor frequência, com maior ou menor angústia. Não exatamente porque acredita-se que haja um sentido único ou até mesmo qualquer sentido estável, mas porque parece necessário - ou inevitável-passar por essa pergunta-assombração, abrir caminho para a lenta paranoia que se aloja no instante em que intuímos o surgimento da dúvida, do impasse e da hesitação diante do sentido. Seria difícil imaginar também uma pergunta direcionada à literatura que não passasse pelo sentido, o que parece indicar que esta tese em teoria literária, pelo menos nesta parte que se anuncia como uma segunda introdução, começa de modo promissor. Somente a pergunta pelo sentido pode dar lugar a isso que chamamos de literatura, à linha que costura o ato da escrita e o da leitura. Mas é também naquilo que imaginamos estar mais longe da literatura que se aloja uma pergunta pelo sentido - qual o sentido de escrever aqui, agora, no país do golpe, uma tese em literatura? Qual o sentido de uma tese no momento do desmonte do sistema público de educação e pesquisa? Qual o sentido da literatura - isto é, de uma discussão sobre o sentido do sentido - no momento em que as forças mais perversas se fazem valer da linguagem e sua contingência para criar uma narrativa que mantém com a referencialidade uma relação de estatuto complexo, para 
não dizer delirante? Como nem todos os absurdos são equivalentes, o trabalho do crítico literário não deixa de ser também uma espécie de investigação a respeito daquilo que constitui os bons e os maus delírios - se delirar quer dizer, em sua origem etimológica, semear fora do lugar, a questão parece dizer respeito ao que é semeado, por quem e como. Claro, porque não seria possível isolar os delírios daquilo que conforma o que se chama de real, o que se dispõe sobre o espaço e tempo de tal forma que podemos chamá-lo de material, sem com isso condenar o mundo a uma espécie de mudez. Em um poema de João Cabral de Melo Neto sobre o fim do mundo, sabe-se que cidades telegrafam pedindo querosene e os homens lêem jornais. Nenhuma palavra sobre as mulheres. Nenhuma palavra sobre os analfabetos. Mesmo assim, ou talvez por isso, ele diz que ninguém escreverá o poema final desse mundo particular de doze horas. / Em vez de juízo final a mim me preocupa o sonho final. Esses versos parecem conter uma teoria bastante comum da poesia ao longo dos séculos sobre o sonho como aquilo que não requer a literatura, mas sem a qual a literatura não existiria. Em Murilo Mendes, a mulher do fim do mundo dá de beber às estátuas / dá de sonhar aos poetas. No ĺon, de Platão, o ponto é convencer o rapsodo de que nada que ele diz lhe é próprio. E como segundo Blanchot é a noite quem sonha, não havendo mais um eu que acorda para dar bom dia ao fim do mundo, esse sonho final que instiga João Cabral não chegaria nunca ao seu termo. Seria Deus um sonhar?, pergunta o povo Walpiri na Austrália Central. O sono é uma espécie de encontro com a finitude, a escuridão cósmica da noite alojada sob a nossa pálpebra, sob a nossa pele, e o sonho são os vestígios que trazemos desse lugar indeterminável e sem duração. Now, you say, doesn't thinking fall asleep and give way to fantasies?, pergunta Jean-Luc Nancy, complementando imediatamente com: Don't think it for a second. Though it still remains true - painfully true - that the sleep of 
reason gives birth to monsters, it is not less true that it is by letting itself to be inclined to sleep, to dream, and to the possibility of no longer waking that thought lets itself awaken to the last possible day of its full probity: the first day, the day without day of our holy eternity.

Nos meses finais da escrita da tese tive um sonho recorrente segundo o qual eu me encontrava em um carro sem direção - embora isso não fosse em si motivo de espanto - que corria por pistas expressas entre edifícios luminosos de uma imensa cidade vazia. Todos os letreiros neons e as placas de saída diziam a mesma coisa: THESIS. O carro continuava percorrendo sempre a mesma pista, acreditando assim, imagino, estar desviando dos caminhos da tese sem perceber que já se encontrava no seu mais pleno transcurso. Como eu tinha certeza de que não sonhava em latim, a pergunta seguinte só poderia ser Por que em inglês?, que parecia se tornar, naquele momento, a incorporação de uma pergunta feita a mim no exame de qualificação em relação à decisão de deixar as citações de Derrida em inglês no relatório de qualificação. E aí o sonho passava a ser também sobre a banca. Sobre a banca e a sua pergunta pela língua, pela linguagem. A tese - e aquilo que possivelmente garante seu pertencimento ao gênero tese, isto é, o evento da defesa - é movida por uma espécie de antecipação do seu juízo final. Essa cena final, que se condecora também como um rito de passagem, que imaginada e reimaginada produz hipóteses acerca das interlocuções possíveis - os elogios, as críticas -, constitui-se como uma espécie de caixa de ressonância do texto à medida que ele é escrito, de onde surgem métodos elaborados de blindagem, controle e evasão. Deleuze dizia que em uma entrevista o mais importante não era saber responder às perguntas, mas fugir delas. Permanecer em estado divinatório: nada pode ser mais enlouquecedor. $E$, no entanto, se houvesse uma forma em que todos pudessem 
escapar juntos desta sala, haveria de ser por meio de uma pergunta acerca dos sonhos da banca. Com o que sonha a banca, com o que sonham as pessoas da banca, essas pessoas que se encontram, de repente, nas variadas gradações do acaso, na condição de destinatárias deste texto? Talvez poucos elementos aproximem mais a banca, precisamente no momento em que ninguém pode dormir, àquela que supostamente defende o seu texto do que o sono que invadiu suas respectivas leituras ao longo dos dias; do que o sim que teríamos dito ao bocejo nesses momentos de estudo. Manifestar aqui esse desejo particular de fuga coletiva pode se assemelhar a um momento pedagógico peculiar: a descoberta de que é possível encerrar as redações escolares com e aí ela acordou. Tudo tinha sido um sonho, só para aprender ao receber de volta a redação que a professora lia aquilo como um sinal da mais óbvia preguiça.

Agamben, em um texto curto sobre a dificuldade de ler, como um padre que diz que também peca, dirige-se ao leitor para compartilhar daquele momento possivelmente comum a todos aqueles que leem, em que gostaríamos de ler, mas não conseguimos, em que nos obstinamos folheando as páginas de um livro, mas ele literalmente cai das mãos. Depois continua para dizer que nos tratados sobre a vida dos monges, isso era, por excelência, o risco ao qual o monge sucumbia: a acídia, o demônio meridiano, a tentação mais terrível que ameaçava os homines religiosi. A acídia chegou a compor os pecados capitais em um momento em que eles eram oito, mas a indefinição de sua especificidade, entre a tristeza e a preguiça, fez com que ele fosse excluído da lista. No tratado de Sancto Nili, o olhar do acidioso pousa obsessivamente sobre a janela e, com a fantasia, finge ser a imagem de alguém que vem visitá-lo. Se lê, interrompe inquieto e, um minuto depois, cai no sono; esfrega o rosto com as mãos, estica os dedos e, tirados os olhos do livro, fixa-os sobre a parede; de novo os volta para o livro, vai em 
frente por mais algumas linhas, balbuciando o final de cada palavra que lê; e enquanto enche a cabeça com cálculos ociosos, conta o número das páginas e das folhas dos cadernos; e as letras e as belas miniaturas que têm diante dos olhos se tornam odiosas até que, por fim, fecha o livro e o usa como travesseiro para a sua cabeça, caindo num sono breve e não profundo, do qual é despertado por um senso de privação e de fome que deve saciar. Interessantemente, a questão para a doutrina religiosa não parecia ser apenas a sonolência e a impossibilidade da leitura; a sonolência é agravada pelo fato de que ela impactaria diretamente no modo de leitura, dando a ele outras formas, formas com as quais a igreja não estava de acordo. Segundo Alcuíno, acometido pela acídia, o monge: no se alegra en los santos deseos ni encuentra regocijo en ayudar a sus hermanos, sino que solamente anhela y desea, y su mente vaga por todo tipo de pensamientos. O perigo está, então, em uma leitura permeada por outros desejos, desejos que provocam um divagar e uma instabilidade no ato de ler. De acordo com o tratado de Evágrio do Ponto, isso é obra do demônio, de um demônio que curiosamente cita e se apropria da sagrada escritura para fazer prevalecer suas intenções: El demonio, entonces, le aconseja desear otros lugares porque, como dice la Escritura, Dios puede ser adorado en cualquier parte $(J n .4,21)$. El demonio apunta todas sus armas para que el monje abandone la celda y huya del lugar. Este outro modo de leitura - o modo acídico e diabólico - é carregado de desejo, mas não apenas de qualquer desejo; de um desejo que expande a leitura, promovendo o abandono e a fuga para um lugar onde, entretanto, ainda é possível adorar a deus. Para Barthes, é justamente porque toda leitura é atravessada pelo desejo (e pela repulsa) que uma doutrina da leitura, a Anagnosologia, é difícil, talvez impossível - em todo caso, que ela tem possibilidade de efetuar-se onde não esperamos, ou pelo menos não exatamente onde a esperamos. Não exatamente ali 
no claustro, às vezes nem exatamente ali no livro.

Ao longo da sua vida universitária Derrida precisou muitas vezes provar seus afetos, ora pela filosofia, ora pela literatura, afetos que para seus críticos não estariam evidentes em suas leituras pois encontravam-se em lugares irreconhecíveis - perhaps all I wanted to do was to confide or confirm my taste (probably unconditional) for literature, more precisely for literary writing. Not that I like literature in general, nor that I prefer it to something else, to philosophy, for example, as they suppose who ultimately discern neither one nor the other. Not that I want to reduce everything to it, especially not philosophy. Literature I could, finally, do without, in fact, rather easily. If I had to retire to an island, it would be particularly history books, memoirs, that I would doubtless take with me, and that I would read in my own way, perhaps to make literature out of them, unless it were to be the other way round, and this would be true for other books (art, philosophy, religion, human or natural sciences, law, etc.). But if, without liking literature in general and for its own sake, I like something about it, which above all cannot be reduced to some aesthetic quality, to some source of formal pleasure [jouissance], this would be in place of the secret. In place of an absolute secret. There would be the passion. There is no passion without secret, this very secret, indeed no secret without this passion. In place of the secret: there where nevertheless everything is said and where what remains is nothing - but the remainder, not even of literature. A imagem da confissão é fantástica: Jacques Derrida, em uma ilha deserta, despreocupado com a ausência de obras literárias, pois está munido de um raio que torna tudo aquilo que lê em algo literário, através do qual surge um modo de leitura que permite que a literatura esteja em toda a parte, não exatamente em função de algo que seria reduzível a uma qualidade estética, mas por meio da investigação da relação entre a paixão e o lugar do segredo. 0 
que quer dizer gostar da literatura no lugar do segredo? Quer dizer gostar daquilo que existe da literatura no segredo, em segredo, isto é, o que existe de secreto na literatura? Ou quer dizer gostar da literatura em vez de gostar do segredo, a literatura como um segredo alterno; um segredo cujo segredo é que não há segredo algum?

Uma ilha é um pouco melhor que um claustro e por isso, agora, no lugar do segredo, sem nenhuma pretensão de retirar da cartola dois coelhos tristes, vou contar um sonho de Anne Carson sobre um cômodo de sua casa. Esse sonho é relatado em um texto que começa dizendo: I want to make praise of sleep. Not as a practitioner-I admit I have never been what is called "a good sleeper" and perhaps we can return later to that curious concept - but as a reader. There is so much sleep to read, there are so many ways to read it. Neste elogio ao sono, ele não mais aparece apenas como aquilo que provoca um modo de leitura distinto, mas torna-se algo do qual é possível aproximar-se na condição de leitor. O sonho que ela conta é também, ela diz, sua primeira memória - o que sugere algo interessante sobre o sonho e a memória, ambos habitando uma área cinza no que diz respeito aos seus supostos referentes. It was in the house where we lived when I was three or four years of age. I dreamed I was asleep in the house in an upper room. That I awoke and came downstairs and stood in the living room. The lights were on in the living room, although it was hushed and empty. The usual dark green sofa and chairs stood along the usual pale green walls. It was the same old living room as ever, I knew it well, nothing was out of place. And yet it was utterly, certainly, different. Inside its usual appearance the living room was as changed as if it had gone mad. Relatar um sonho a outra pessoa não é um evento trivial, pois exige narrar algo cujo funcionamento não se dá necessariamente sobre um eixo espaço-temporal mensurável 
e reconhecível. Benjamin, nas Passagens, pergunta: pois quem conseguiria com um só gesto virar o forro do tempo do avesso? E, todavia, relatar sonhos nada mais é do que isso. Os parâmetros para aquilo que constitui uma narrativa, uma concatenação lógica de ações que se sucedem sobre uma linha temporal (mesmo que seja possível avançar e retroceder sobre ela) estão largamente dilatados nos sonhos, de modo que as coisas ali sempre são e não são simultaneamente - a mesma casa, mas completamente diferente. No momento em que isso acontece, a linguagem começa a se ver induzida a curtos-circuitos - afinal, sonhar estar dormindo parece inviabilizar o próprio sonho e no entanto, ela continua, acorda, ainda no mesmo sonho, e segue sonhando para depararse com uma casa - a sua - que enlouqueceu, embora ela tome cuidado para modular essa afirmação com o como se. Em um texto sobre a epistemologia das figuras de linguagem, Paul de Man escreve que when one speaks of the legs of the table or the face of the mountain, catachresis is already turning into prosopopoeia and one begins to perceive a world of potential ghosts and monsters. Carson diz it was the same old living room, a mesma sala, mas no seu sonho, sobretudo, é uma sala viva. E por que é viva, dorme. So, as far as I can recall, I explained the dream to myself by saying that I had caught the living room sleeping. I had entered it from the sleep side. Aqui já não há mais modulação, parece tratar-se de uma convicção - é possível também habitar o mundo pelo lado do sono, vê-lo funcionar sob rasura. Anne Carson pegou no sono e pegou a sala também no sono; pegar no sono é sempre uma surpresa pois não é possível prever exatamente o momento, porque o sono nunca pode ser pego - e por isso em inglês uma pessoa sempre cai em um sono já em andamento. And it took me years to recognize, or even to frame a question about, why I found this entrance into strangeness so supremely consoling. For despite the spookiness, inexplicability and later tragic reference of the 
green living room, it was and remains for me a consolation to think of it lying there, sunk in its greenness, breathing its own order, answerable to no one, apparently penetrable everywhere and yet so perfectly disguised in all the propaganda of its own waking life as to become in a true sense something incognito at the heart of our sleeping house. Aqui a cena é outra, não é mais um claustro, nem uma ilha, mas uma sala adormecida. E essa sala, no seu adormecer, ao mesmo tempo em que parece infinitamente legível, se esconde no excesso de seus próprios recursos, se expõe sem se revelar, e nessa dinâmica instável aponta também, como em Derrida, para a relação entre o segredo e o coração, como se a questão literária fosse, então, a possibilidade de ler, de entrar no texto pelo lado do sono.

Um segredo no coração da casa não quer dizer um segredo no centro da casa, quer dizer um segredo naquilo que dita o seu ritmo, naquilo que embala a oscilação entre presença e ausência. A impressão ao ler as partes (os capítulos?) que seguem pode ser de um excesso - um excedente de referências, de ideias, de associações -, excesso que rapidamente e necessariamente desembocará em uma sensação de falta - falta de rigor, de interpretação de texto, de literatura. Buffon, em seu tratado biológico sobre os monstros, escrito no século XVIII, afirma que se pueden reducir en tres clases todos los monstruos posibles: la primera es la de los monstruos por exceso; la segunda, la de los monstruos por defecto, y la tercera la de aquellos que los son por la alteración o la equivocada posición de las partes. Se menciono isso aqui, é porque eu frequentemente oscilei entre leituras do meu próprio texto, entre uma soneca e outra, precisamente naqueles momentos em que ele parecia o texto de outra. A ausência, no entanto, não deve ser confundida com a falta: Anne Carson, mais adiante em seu elogio ao sono, diz que viewed from the sleep side, an empty eye socket is just a fact about a person, not a 
wish to be fulfilled, not a therapeutic challenge. Por outro lado, seria quase redundante falar na falta ao longo desses quatro anos e meio: na falta de tempo, na falta de condições, na falta de janelas na biblioteca da FFLCH (ou seriam as grades o problema?), na falta que algumas pessoas fazem e fizeram, na falta que pode fazer um menisco, neste momento do texto que - se ele desta vez for uma introdução de verdade - costuma ser dedicado a um comentário sobre a sua contingência e um aceno positivo à vontade de ter feito muito mais, além de justificar a sua existência pelos meios julgados necessários ou adequados. Aqui eu também estou fazendo isso, justificando a falta, ao mesmo tempo em que esses espaços em branco - as ausências - me parecem estender-se em gesto afirmativo, operando por sugestão. Em Argonautas, Maggie Nelson fala não sobre o sonho de Anne Carson, mas sobre os colchetes vazios de Carson, como respostas a perguntas em uma entrevista. Por um lado, diz Nelson, o não dito parece transformar-se em obsessão e recusa de conviver com o indizível que existe na própria linguagem, por outro, é importante sempre deixar os colchetes abertos para deus.

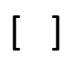

Os colchetes são de fato apropriados aqui, já que houve sempre a tentativa de sugerir algumas conteções para o que pareceria ser irrefreável, de retornar ao quarto, à ilha, às vezes até mesmo ao claustro. Voltando ao sonho, Anne Carson diz it was and remains for me a consolation to think of it lying there, sunk in its greenness, breathing its own order, answerable to no one. A questão sobre a garantia a priori de um direito à não-resposta, isto é, a ausência de uma obrigação de responder, associada à ausência de uma espécie de origem, constituiu grande parte dos limites explorados, desdobrados de diversas maneiras nas partes que seguem. $O$ pesadelo acontece justamente quando se cruza essa linha, quando a sala se converte em abismo e acordamos caindo, nenhum 
consolo. Em inglês, a palavra para pesadelo é nightmare, mas isso não quer dizer que cavalgamos uma égua descontrolada, mare é antes um espírito feminino que monta o cavalo e o faz acordar suado. Uma tentativa de formular essa questão, que no fundo é uma questão sobre a imunidade, pode ser a seguinte: é possível uma responsabilidade sem sujeito, isto é, é possível estar sujeito a sem ser sujeito? Fazer aos sonhos uma pergunta sobre a responsabilidade não é muito diferente de quando Herzog pergunta ao espeleólogo se a caverna sonha, e com o quê, no filme A caverna dos sonhos esquecidos, mas é justamente o que fez a alemã Charlotte Beradt entre os anos de 1933 e 1939. Após a ascensão de Hitler ao poder, Beradt, então uma jovem jornalista, começa a pedir que conhecidos Ihe relatem seus sonhos, sonhos ditados pela ditadura, depois ampliando esses narradores particulares para um espectro mais amplo de pessoas. Sua justificativa é bastante pragmática: caso o regime, como um fenômeno da época, viesse a ser julgado algum dia, esses sonhos poderiam ser usados como provas, pois pareciam estar repletos de informação sobre os afetos e os motivos das pessoas quando acionadas, como pequenas rodas, ao mecanismo totalitário. Os sonhos coletados por Beradt comprovam aquilo que talvez nem o chefe de organização do partido nazista, Robert Ley, conseguiu prever em seu decreto, segundo o qual a única pessoa que tem uma vida privada na Alemanha é aquela que dorme. Um homem sonha com um decreto emitido por um altofalante que imediatamente dissolve as paredes de sua casa; uma mulher sonha que os anjinhos pendurados sobre a sua cama não olham mais para o alto, mas para ela; outro homem sonha que é acusado de anotar seus sonhos. Contra isso, uma jovem faxineira encontra uma solução, uma forma de não ter como responder a um suposto interrogatório acerca de suas atividades não-conscientes: sonho que, por precaução, falo russo enquanto durmo (não sei falar russo e também não falo durante o sono), para que 
eu mesma não me compreenda, e, assim, ninguém me entenderá caso eu diga algo sobre o Estado, pois isso é proibido e precisa ser denunciado. A questão aqui não seria criar uma espécie de código secreto, mas ocultar de si mesma a informação de modo a não correr nenhum risco de ser implicada em crimes, isto é, ir buscar em outra língua uma forma de garantir, por via das dúvidas, aquilo que Jean-Luc Nancy afirma sobre a pessoa que dorme: I sleep and this I that sleeps can no more say it sleeps than it could say that it is dead. So it is another who sleeps in my place. A ausência de um sujeito do sono induz a uma espécie de instabilidade, pois se, por um lado, esse sonho, como outros no livro, parece apontar para o absurdo de julgar e condenar alguém por aquilo que sonhou Beradt inclusive comenta que em Auschswitz uma prisioneira que servia como secretária perguntou a uma companheira de dormitório se acaso ela falava durante o sono sobre os assuntos que escutava no seu posto, pois éramos ameaçadas para que não revelássemos nem por palavras, nem por mímica, o que ouvíamos no departamento político - por outro, o que impele a coleta de sonhos é justamente a crença de que é possível levá-los ao tribunal como evidências contra o regime nazista. Não menos curioso é o fato de que o funcionamento que Derrida descreve para a responsabilidade se aproxima, e muito, do que Nancy diz sobre a pessoa que dorme: it is the other in me who-or which-decides. Seria muito difícil desenvolver aqui mais sobre aquilo que poderíamos nomear provisoriamente como uma ética ou uma política dos sonhos, embora a questão seja muito interessante, e necessária. Provavelmente seria preciso desviar da relação onírica inóspita do ocidente moderno, mediada hoje quase exclusivamente pela psicanálise ou por guias de interpretação de sonhos, segundo os quais, por exemplo, sonhar com a letra F simboliza a perda de estabilidade, já que a letra F nada mais é do que a letra $E$ sem fundação, e ir buscar esses rastros, por exemplo, em 
A Queda do Céu, de Davi Kopenawa, onde a questão parece ser justamente essa: deixar que os xapiris armem para si redes nos sonhos, manter aberta nos sonhos uma morada para que o céu não caia de novo, sonhos contra o deus-mercadoria. Os xapiri vinham muito me visitar em sonho. Desse modo, começaram a me conhecer bem. Diziam para mim: Como você responde ao nosso chamado, vamos dançar para você e pendurar nossas redes na sua casa de espíritos.

Mas, por ora, essa não é exatamente a minha questão, porque acordar é inevitável. A não ser que isto já não importe mais, que já não seja mais uma questão de ida e volta, e nesse sentido, retornar do sonho é retornar ao quarto, mas sobretudo ao corpo. No momento deste percurso de volta, dizer eu acordo parece tão impossível quanto dizer eu durmo. Não saber onde acordou, por exemplo, depois de alguma mudança de rotina, puxado para fora do sono para um território que, pelo menos por alguns instantes, é irreconhecível. Déborah Danowski, em um texto chamado Dic cur hic? Ou o que significa estar aqui?, retoma a noção ética de Leibniz a partir das reflexões de Proust, nas primeiras páginas do Em busca do tempo perdido, sobre dormir e despertar. Dic cur hic, essa expressão que parece um soluço, quer dizer diga por que aqui? Uma pergunta boa para uma introdução: por que aqui e não lá; o que significa estar aqui?

A disposição, ela diz, dos nossos corpos, assim como a nossa posição, importam; a consciência de quem somos e do lugar que ocupamos depende dessa lógica gravitacional, que se reconfigura durante o sono. Retornar ao corpo depende de compreender como ele chegou ali, e ainda resta a pergunta sobre o que é que, afinal, retorna. Assim, dependendo da posição e situação (reais ou imaginárias) que ocupamos, seremos já exatamente esta pessoa que somos agora, acordando de um sono longo ou 
curto, ou, por alguns instantes, a pessoa que éramos há alguns anos, dormindo no quarto de uma amante, ou ainda a criança que fomos há muito tempo, em um quarto e uma cidade completamente diferentes. O processo de despertar plenamente para a propriocepção, organizar-se espaço-temporalmente em relação à cama e ao quarto esse processo muitas vezes espontâneo mas também ocasionalmente assustador, como quando se acorda e não é possível mexer o corpo, abrir os olhos - sofre interferências de outras camas, outros tempos. Mas, o texto continua, agora citando Proust, se ali não ficamos, é graças à memória, do corpo antes que do pensamento ("a memória de suas costelas, de seus joelhos, de suas espáduas"), que vem agora em nosso socorro, arrastando-nos em alguns segundos pelo longo caminho de volta: da indistinção da pura existência à existência humana, $e$, dentro desta, passando rapidamente por séculos $e$ séculos de civilização, até os lampiões de querosene, as camisas de gola virada, os lugares onde estivemos ou onde poderíamos estar, até chegar ao nosso quarto e nosso eu, aqui e agora, tudo finalmente imobilizado pelo "bom anjo da certeza".

Anne Carson, antes de contar os seus sonhos, diz que ela não dorme bem, ou melhor, ela diz algo como não ser boa em dormir, como se dormir fosse uma atividade equivalente a outras, como se se tratasse de aptidão. Na insônia, diz Danowksi, também abandonamos a planta do nosso quarto, nosso cur hic. Passamos a galopar em séries autorreflexivas, constituídas de reflexões sobre reflexões sobre reflexões... Aqui também há um perigo, o de não poder frear o próprio galope ou conduzi-lo em outra direção, pois trata-se também, como nos sonhos, de um regime de apercepção, e o risco é ficar determinado a repetir obsessivamente a mesma percepção, em múltiplos cada vez mais vazios, tentando sempre levar a série às últimas consequências, esquecendo a memória do corpo. Assim como o soluço nos lembra que um dia habitamos o oceano, a pergunta 
de Leibniz, dic cur hic, coloca um limite que nos permite voltar ao nosso quarto humano todas as vezes em que o abandonamos temporariamente por esquecimento ou atordoamento. Entendo humano aqui como uma consciência de espécie, procurando formas de construir corpos habitáveis, compreender o corpo como a medida de estar no mundo e assim, nos resgatar da pura transcendência, quando esta significa mais uma vez deixar para trás a planta do nosso quarto, agora por excesso de memória e por hipertrofia de nosso dom reflexivo. Na primeira introdução, Benjamin já avisou que o juízo final é a citação de tudo aquilo que algum dia já aconteceu.

O que significa estar aqui? Entre os animais e os drones, a radiação e a hipnose, os feminicídios e o EZLN, entre essas vozes em itálico? Entre rotas de fuga e becos sem saída? É que, como veremos, manter a integridade dos corpos vulnerabilizados às vezes - e dependendo da situação, sempre - requer que um não seja simplesmente um não.

Carson, depois de contar o seu sonho, fala sobre os sonhos na obra de Virgínia Woolf, ela diz que os livros de Wolf adormecem ao longo de páginas. Em The Voyage Out, ela diz, the dreams were not confined to her indeed, but went from one brain to another. They all dreamt of each other that night, as was natural, considering how thin the partitions were between them and how strangely they had been lifted off the face of the earth to sit next each other in mid ocean... Os personagens, à bordo de uma ilha movente, isto é, um barco, realizam uma travessia para a América do Sul. Sonham juntos. A pergunta que começa a se esboçar aqui é pelo destinatário dos sonhos, e sobre a possibilidade do sonho poder instaurar uma espécie de comunidade. Se, novamente, nos afastamos das perspectivas ocidentais, encontramos inúmeras respostas afirmativas, naturezas que dependem inteiramente disso, como os Walpiri, que sonham 
para percorrer os caminhos de seus ancestrais criadores. Uma cantiga popular brasileira também partilha da possibilidade de sonhar para um outro: Xô meu sabiá, xô meu zabelê / Toda madrugada eu sonho com você / Se você não acreditar eu vou sonhar pra você ver, sonhar para que outro veja, para que o sonho prove aquilo que se afirma. Leonilson, cuja poética parece interessar-se sobretudo pela questão do destinatário, como em seu travesseiro bordado para ninguém, ou um pedido de aceitação ao oceano, bordou também um pano amarelo com a inscrição: para o meu vizinho de sonhos, o que sugere uma relação sempre tangencial (Angélica Freitas já avisa: quem quiser dormir comigo / vai ter que dormir do lado). Há outro, desta vez um endereçamento condicionado à matéria dos sonhos, ou talvez ao lugar em que ocorrem, ou ainda a uma aliança improvável, se você sonha com nuvens. E também, em outra versão, na sua máxima abrangência, completamente aberta para o futuro: você que espero imenso e não sei quem é. No fundo, ou pelas bordas, a pergunta é pelos destinatários da tese, que não podem ser reduzidos à banca, nem mesmo a uma banca que sonha ${ }^{8}$.

\section{Supe que alguien}

largo tiempo había dormido

sobre mis escritos.

\footnotetext{
${ }^{8} \mathrm{E}$ no entanto, parece que a tese foi escrita também para a banca - isto é, para as pessoas que naquele momento da defesa estavam investidas do poder de banca -, que me lembraram dos perigos de sonhar o sonho do outro, de sonhar para outro, de pedir que o outro sonhe o meu próprio sonho, quando o mais importante parece ser, justamente, sonhar com o outro, os outros, as outras. O sonho já é desde sempre isso: uma convivência particular, uma aparição inesperada. No fim, uma tese se escreve para ninguém, o que também pode querer dizer que ela é escrita para todo mundo; o mais precioso mesmo é escrever com: com aqueles que sabem o que pode significar escrever uma tese e com aqueles que nem imaginam. Agradeço imensamente à Ana Cecilia Olmos, à Carla Rodrigues, à Juliana Fausto e ao Tiago Guilherme Pinheiro pelas generosas leituras e sugestões.
} 
Nuestro buen artesano escribe. Está ensimismado en aquello que va plasmando bien o mal en el papel. Su mujer, sin que él lo sepa, lo observa. Efectivamente, es él quien escribe. Pero si su mujer tuviera una vista de rayos $X$ se daría cuenta de que no asiste propiamente a un ejercicio de creación literaria sino más bien a una sesión de hipnotismo. En el interior del hombre que está sentado escribiendo no hay nada. Nada que sea él, quiero decir.

Anderson Gray era um rico fazendeiro no Kansas. Um de seus vizinhos passava por um divórcio em que era quase garantido que a sua esposa permaneceria com a propriedade. O vizinho decidiu, então, passar o nome de suas terras a Gray temporariamente. Thomas Patton foi a única testemunha da transação. O processo de divórcio encerrado, o vizinho pediu a Gray que retransferisse a fazenda ao seu nome, mas suas intenções eram outras. Havia apenas uma testemunha em seu caminho: Patton. Além de fazendeiro e rico, Gray era também um estudioso das forças da hipnose: sua primeira tentativa de livrar-se de Patton foi hipnotizá-lo para que atirasse em um primo seu. Gray deu a Patton uma arma defeituosa e imaginou, com isso, que este seria morto pelo primo, em autodefesa. Mas não foi assim. Gray então contratou o jovem Tomas McDonald para vir trabalhar em sua fazenda, ensinou-o a atirar, idealizou uma emboscada e, por meio da hipnose, sugeriu que McDonald matasse Patton, ato levado a cabo com precisão.

A notícia está na edição do The New York Times de 8 de abril de 1895 e alcançou repercussão nacional por ser o primeiro caso de jurisprudência para o qual a hipnose foi aceita como defesa de um assassinato, sendo julgado culpado quem influenciou por meio do poder de sugestão e inocente quem efetivamente matou, veredito determinado por dois tribunais e um júri, entre eles a Suprema Corte do país. McDonald 
was arrested and confessed all, but insisted that he was under Gray's influence and could not help but do what his hypnotic master "suggested". He unhesitatingly admitted having killed Patton, but refused to consider himself as the real murderer. He insisted that he had no motive for the crime, and that while he knew what he was doing, he remembered the act with a dreamy indefiniteness and did not at the time realize the consequences of his action. He said that had it not been for Gray he never would have spoken to Patton, and had it not been for the hypnotist's "suggestion" he would never have practiced with the rifle and would never have shot his victim. Os fatos parecem pertencer à ordem da improbabilidade: McDonald, apesar da hipnose, é capaz de "confessar tudo" e a sua confissão, a despeito também indução hipnótica da qual foi objeto, é considerada confiável e crucial para a sua absolvição. A manchete é "HYPNOTISM AS A DEFENSE - Story of the Case in Which the Actual Murderer was Acquitted and the Hypnotizer Convicted" e na mesma edição há também uma entrevista com o Juiz McAdam, da Corte Superior, que afirma a hipnose em sua condição de reconhecimento legal, visto que the hypnotic condition is no longer a subject of speculation. It stands as one of the recognized forces in life, and any tribunal before which it is brought in any of its relations must recognize it. Além disso, o mesmo juiz determina que a secção 29 do Código Criminal legisla sobre o caso em questão, visto que já está prevista a condenação de qualquer pessoa envolvida no mando de um crime, quer ela cometa diretamente o ato ou auxilie no seu mando, quer ela esteja presente ou ausente na cena do crime, e da pessoa que dirige, aconselha, comanda, induz ou solicita que outro cometa um crime. 
No final do século XIX a hipnose era, além de um assunto de larga difusão popular ${ }^{9}$, um assunto de interesse tanto jurídico quanto médico; a reputação científica de Jean-Martin Charcot, neurologista, médico de Salpêtriére, colocou-a como objeto de sérios estudos e debates em que se tencionava a extensão do poder de sugestão. Para Charcot, a hipnose se caracterizava como um epifenômeno fisiológico da histeria - e da forma como ele a propunha, a histeria não era apenas feminina ${ }^{10}-$, dividida em três fases do "grande hipnotismo": catalepsia, letargia e sonambulismo. Nos seus tratados médico, expunha a hipnose como uma espécie de neurose histérica artificialmente induzida, pois considerava-se o sonambulismo natural como precursor da histeria e o sonambulismo hipnótico, portanto, era compreendido apenas como uma manifestação adicional da histeria. Por outro lado, a école de Nancy, em confronto direto com as ideias de Charcot através da figura do médico Hippolyte Bernheim, concebia a hipnose não como uma patologia do sistema nervoso, mas como um estado semelhante ao sono, isto é, um sono induzido que não diferia do sono natural e explicava, assim, o motivo pelo

\footnotetext{
${ }^{9}$ Em 1887, só em Paris, era possível, segundo Tourettes, encontrar de quatrocentas a quinhentas vitrines que mostravam sonâmbulos; as forças hipnóticas também estavam presentes em vários textos literários, como "O Horla" (1887), de Guy de Maupassant, "Sob uma vontade alheia" (1888), de Gregor Samarow, ou "Sob o fascínio da hipnose" (1897), de Wilhelm Walloth.

${ }^{10}$ Didi-Huberman, em A invenção da histeria: Charcot e a iconografia fotográfica de Salpêtrière, afirma que o asilo, no último terço do século XIX, continuou sendo o que sempre tinha sido: uma espécie de inferno feminino, uma città dolorosa que encerrava 4 mil mulheres incuráveis ou loucas. Um pesadelo em Paris, bem perto de sua belle époque. Houve quem a descrevesse como a Versalhes da dor, ou como a outra Bastilha e lá, muitos diziam, mais do que estudar a histeria, o intento era de cultivá-la. DidiHuberman concede o fato de que Charcot realmente afirmava que a histeria no homem não era tão rara como se supunha e que suas policlínicas, longe de Salpêtrière, estavam cheias de homens histéricos. Seu trabalho de iconografia fotográfica, porém, transcorreu por seis anos sem nenhum homem fotografado. Trata-se de uma tática de diferenciação entre os sexos. O fato de se elevar a histeria ao nível de um "temperamento" não modifica nada, muito pelo contrário: como "temperamento feminino transformado em neurose". A histerizição instituída, se não institucionalizada, do corpo da mulher persistiu e até voltou a ser fabricada no século XIX; aí o asilo se redefiniu, por exemplo, como a inversão medicalizada da casa de tolerância (...porque da histérica à prostituta havia apenas um passo, e simples: transpor os muros da Salpêtrière e se descobrir na rua...); em suma, todos os processos de invenção generalizada de uma sexualidade de época ainda compreendiam a histeria como uma posse de feminilidade. Assim, é preciso registrar o fato de que essas imagens de Iconografia fotográfica da Salpêtrière, antes de tudo, extraem traços, extraem traços de mulheres.
} 
qual parte significativa das pessoas era "sugestionável", muito embora não sofressem de sintomas histéricos. Bernheim definia, então, o hipnotismo como indutor de um estado específico de maior sugestionabilidade. Ambos, porém, concordavam que o poder hipnótico da mente sobre o corpo chegava ao ponto de tornar ilimitado o controle do hipnotizador sobre seu médium. Charcot, descrevendo a fase sonambúlica do "grande hipnotismo", afirmou que nosso poder não encontra nenhum limite nesse campo, pois podemos estender nossa influência quase ao infinito. Bernheim representava o sujeito hipnotizado como um autômato controlado por uma vontade externa, de modo que seria possível que uma pessoa fosse hipnotizada até contra a sua vontade, transformando-a em um corpo remoto, uma espécie de possessão.

No livro Possuídos - crimes hipnóticos, fiç̧ão corporativa e a invenção do cinema, Stefan Andriopoulos afirma que depois de 1885, uma onda espantosa de livros e artigos de direito e medicina alertou para o "espectro aterrador do crime sob hipnose". Médicos passaram então a encenar simulações de crimes sob transe hipnótico, encenações geralmente realizadas diante de plateias jurídicas, mas também para um público leigo, com o intuito de provar que estes crimes eram possíveis. No palco, sob efeito da hipnose, os pacientes eram munidos de armas com balas de festim e atiravam ao menor comando; em outra versão, oferecia-se açúcar como veneno e ordenava-se o envenenamento do assistente de palco. O método experimental, é claro, não se constitui pela observação pura e simples, mas por uma observação provocada - isto é, um meio com um fim claro: a obtenção dos fatos, um regime metodológico segundo o qual é preciso fazer os fatos trabalharem em determinada direção. Para muitos médicos e juristas, entre eles Charcot, montados como um espetáculo, teatralizados como um show de mágica, esses experimentos não poderiam ser considerados empiricamente 
decisivos, pois considerava-se possível que aqueles sob o efeito da hipnose tivessem alguma noção de que se tratava apenas de um teatro. Charcot, por exemplo, defendia que o sujeito hipnótico em tal estado de sugestionabilidade e em condições reais sofreria um ataque histérico e colapsaria em catalepsia ${ }^{11}$; apesar disso, como no caso do fazendeiro Anderson Gray, os numerosos tratados jurídicos sobre crimes praticados sob hipnose, como Hipnotismo e direito penal (1887), de Karl Lilienthal, Hipnose e sugestão no direito penal alemão (1893), de Max Heberle, e Ação indireta e hipnotismo (1900), de Georg Neumeister, expressavam claramente que a pessoa dominada por tal sugestão não é legalmente responsável por seus atos. A proliferação de obras literárias que tratavam do tema da sugestão criminal também corroborava para a criação de uma atmosfera em que qualquer um pudesse estar vulnerável a sugestões, com efeitos desastrosos. Ao comentar a popularidade dessas narrativas sensacionalistas do hipnotismo, o psiquiatra alemão Binswanger observou, em 1892, que hoje em dia, os romances de terror de épocas anteriores celebram sua ressurreição na descrição de sugestões criminais. Muitas obras utilizavam como substrato para os seus argumentos os tratados médicos e jurídicos, de modo que, assim como a encenação, a literatura

\footnotetext{
${ }^{11}$ Andriopoulos não nos dá maiores detalhes sobre as condições efetivas dessas encenações, mas voltando a Didi-Huberman, é curioso que as próprias encenações de Charcot - tão famosas que havia também o museu itinerante do [charlatão] dr. Spitzner, que ia de feira em feira expondo, como sua peça de número 100, um grupo que representava uma "Aula do professor Charcot" em tamanho natural! - suscitavam questões semelhantes quanto a sua credibilidade científica. Salpêtrière era, segundo ele, a grande fábrica de imagens, onde as mulheres eram obrigadas, por assim dizer, a pousar. Havia um jogo de simulação e dissimulação, o que levou também a histeria, e por conseguinte a mulher, a serem condicionadas ao corpo que mente. No inferno de Salpêtrière, as histéricas não paravam de piscar os olhos para seus médicos. Era uma espécie de lei do gênero, não apenas a lei da fantasia histérica (desejo de cativar), mas também a lei de toda a própria instituição asilar. E eu diria que esta possuía uma estrutura de chantagem: de fato, era preciso que cada histérica desse mostras, e com regularidade, de seu "caráter histérico" ortodoxo (amor pelas cores, "leviandade", êxtase erótico, etc.), para não ser transferida para o "setor" duríssimo das simples "alienadas" ditas incuráveis. Assim, a situação de chantagem era mais ou menos esta: ou você me seduz (e por isso mesmo se demonstra histérica) ou eu a considero uma Incurável, e nesse caso, para sempre, você não mais será exibida, mas escondida no escuro. Para as histéricas, portanto, seduzir consistia em confirmar e tranquilizar cada vez mais os médicos quando ao seu conceito de Histeria.
} 
encontrava grandes possibilidades de retroalimentar e, por vezes, pautar as discussões científicas. A paranoia, que era também o revés do êxtase da adrenalina provocado pela leitura dessas obras, se agravava com a possibilidade difundida entre a população de que o sujeito hipnotizado poderia não se saber hipnotizado, ocasionando um cenário em que poderia haver um número ilimitado de crimes desconhecidos, praticados sob hipnose, que não poderiam ser reconhecidos como tais - uma situação médico-legal assustadora. Auguste Forel, médico que lecionava na Suíça, chamava atenção ao perigo especial no emprego de sugestões pós-hipnóticas nas quais, além do crime e do momento estabelecido para a sua prática, a ideia de "volição livre" fosse implantada no sujeito hipnotizado, um dos ardis mais insidiosos da sugestão, entretanto, reside no uso da determinação do momento, juntamente com a implantação da amnésia e da ideia de volição livre, a fim de instigar a pessoa a praticar um ato criminoso. Assim, essa pessoa vê-se numa situação que está fadada a criar nela toda a ilusão da espontaneidade, quando, na realidade, ela está apenas seguindo ordens de um terceiro. Freud atribuiu a essas sugestões pós-hipnóticas uma demonstração anterior à psicanálise da existência e atuação do inconsciente.

O jurista George Trumball Lad, em um texto de 1901 comissionado pela organização de advogados de Nova lorque, afirma ser a hipnose incontestável e, além disso, existente ao longo de toda a história humana. Lad discute as possibilidades de regular a atividade da hipnose, já que ele reconhece os seus benefícios, mas conclui que isso seria dificílimo. Sua preocupação principal, no entanto, é revelada ao fim do texto: aquela que diz respeito à sugestionabilidade coletiva, isto é, às forças que, de modo semelhante à hipnose, promovem combined criminal action of lynchers, rioters, and mobs. Seus exemplos são as revoltas em Atenas contra a tradução da bíblia ao grego 
moderno, o levante anti-colonial e anti-missionário dos Boxers na China e as revoltas e linchamentos decorrentes das políticas estado-unidenses de segregação racial. Para Lad, portanto, a sugestionabilidade coletiva parece existir como crime independente dos fins buscados pelas ações coletivas as quais ela dá origem. O perigo aqui está em reduzir as forças hipnóticas exclusivamente a uma ferramenta do mal ou em recusar a considerar os processos conscientes que impelem seres humanos a tomarem parte de revoltas sociais. O seu parecer final, portanto, sugere o fortalecimento do indivíduo contra qualquer espírito de coletividade, embora, é claro, ele não faça menção ao denominador comum entre esses seus três exemplos de sugestionabilidade: as forças de repressão do estado, que só podem existir coletivamente, mas que, segundo a sua percepção, e a minha interpretação dela, estariam imunes à sugestão pois agiriam sempre em função da razão que caracteriza o indivíduo que faz parte de uma corporação.

Em seu livro, Andriopoulos escreve que nessa mesma época, ao mesmo tempo em que se discutiam esses crimes sob hipnose, havia também outro debate sobre o status das corporações ou "pessoas jurídicas" no direito civil e no direito penal. Os estudiosos que seguiam a jurisprudência romana propuseram a "teoria da ficção", segundo a qual a corporação se constituía como uma pessoa fictícia, representada por pessoas físicas ou naturais nas transações legais. Em maio de 1888, o Terceiro Senado Penal da Suprema Corte Imperial alemã concluiu que a empresa de capital acionário [sociedade anônima] não arcava com nenhuma "responsabilidade sob o direito penal". De acordo com a Corte, o fato de a sociedade anônima ser "legalmente habilitada e obrigada em consequência das transações legais praticadas em seu nome por seus representantes" não tinha "nenhuma significação para o direito penal", pois um "sujeito legal fictício" que carecia de "ação natural" não podia ser responsabilizado por crimes 
cometidos em seu nome. Savigny, em O Sistema de direito romano moderno (1884), buscava reestabelecer o princípio romano segundo o qual societas delinquere non potest (uma sociedade não pode delinquir), um pressuposto, diga-se de passagem, da omissão. Para ele, o direito penal dizia respeito à pessoa física como ser pensante, dotado de vontade e sentimento. A pessoa jurídica, porém, não é nada disso, mas simplesmente um ser que possui bens e que, portanto, acha-se completamente fora do alcance do direito penal. Sua existência real depende da vontade representativa de indivíduos específicos, vontade esta que, em consequência de uma ficção, é-Ihe atribuída como sua vontade própria. Tal representação, entretanto, sem o exercício de uma vontade pessoal, só pode ser reconhecida em matéria de direito privado, e não do direito penal. Ou seja, uma pessoa ficta poderia participar de transações comerciais, mas jamais poderia ser culpabilizada por um crime. O estatuto do ficcional na pessoa ficta, é claro, também se encontrava em tensionamento, pois colocava em xeque a lei nos termos em que ela se autodescrevia como um sistema conceitual fechado e coerente: a lei como o oposto da incomensurabilidade da ficção. Gustav Demelius defendia que, sendo as leis ordens, e não instrumentos epistêmicos, elas não poderiam conter ficções em um sentido epistemológico, não sendo correto, portanto, afirmar que elas distorciam os fatos; se assim fosse, admito que essas fiç̧ões realmente seriam, se não poesia, certamente invenções jurídicas semelhantes à literatura. ${ }^{12}$

\footnotetext{
${ }^{12}$ Dorothy Bethurum, em seu texto "Stylistic Features of the Old English Laws", compara o funcionamento do direito antigo inglês com a poesia. Citando Jacob Grimm (mais conhecido pelo Contos de Grimm, mas também um conhecido jurista de sua época), ela afirma que tanto a lei proclamada oralmente quanto a poesia obtém sua autoridade em função da constituição de um espírito de herança. Em outras palavras, ambas a lei e a poesia dependem de estruturas que provêm de um passado distante, ou melhor dizendo: principalmente da constituição aparente da idéia de que provêm de um passado distante. Ambas mobilizam a fé das pessoas nos costumes herdados e passados de geração em geração.
} 
Diante, porém, do aumento exponencial do número e do poder das sociedades anônimas e outras empresas comerciais - os conglomerados de proporções verdadeiramente gigantescas como os verdadeiros protagonistas da vida econômica-, as teorias organicistas da época produziram outra hipótese, segundo a qual pessoas jurídicas poderiam ser responsabilizadas penalmente, ainda que a injunção legal continuasse sedimentando-se sobre uma figura fantasmagórica. De acordo com essas teorias, as pessoas jurídicas eram como organismos sociais que não eram visiveis ao olho físico e não podiam ser seguradas com a mão - no entanto, não só o corporal é real. Otto van Gierke era o mais influente proponente dessa linha, e determinava os organismos sociais como produtos de um substrato ao mesmo tempo corporativo e corpóreo. Diferente do corpo humano, no entanto, esses corpos societários não poderiam ser compreendidos em sua totalidade uma vez que a unidade de sua vida permanecia invisível. A pessoa coletiva não é uma coisa conceitual morta, que precise ser representada por outra pessoa, mas um organismo vivo, que deseja e age como tal. A pessoa coletiva, portanto, possuía uma vontade própria coletiva que era distinta das vontades individuais de seus membros e independente delas; mas agia através desses indivíduos, como um corpo com seus membros ou seus órgãos: a pessoa jurídica é um sujeito que intervém de forma autopoiética no mundo externo. Gierke admitia a possibilidade da culpabilidade individual independente, sem excluir a punição imposta à corporação, para os detentores de cargos em órgãos, a depender da situação. Mas o verdadeiro autor do crime corporativo seria sempre para ele a esfera do espírito coletivo, na qual a vida psíquica do indivíduo é determinada pela força abrangente de uma coletividade espiritual organizada que opera dentro do indivíduo. No campo do discurso teológico, o protestante Daniel Schenke comparou Satanás a uma pessoa 
jurídica, o mal é sempre pessoal; não há mal fora da manifestação da vida pessoal. Mas o mal satânico já não é pessoal em termos subjetivos, e sim coletivamente. Satanás é uma pessoa, juridicamente falando: a chamada pessoa jurídica, uma pessoa coletiva do mal; e é essa a fonte do seu poder, ao menos extraordinário, ao menos relativamente supraindividual. O crime corporativo, assim, era descrito em termos quase idênticos aos dos crimes praticados sob hipnose, invocando uma linguagem parecida, nas quais as imagens de possessão demoníaca também ocupavam uma posição central e, assim, inseria-se na longa tradição de debates teológicos sobre o livre arbítrio. O jurista alemão Franz von Liszt, certo de que era a corporação o verdadeiro culpado, considerava a pessoa que cometia fisicamente o ato ilícito como mero órgão de uma vontade alheia. Em $A$ riqueza das nações, um século antes, Adam Smith já havia criado a imagem sobrenatural da "mão invisível" para refutar a demanda mercantilista de intervenção estatal no processo econômico e o início do século $\mathrm{XX}$, com a sua prática popular de fotografia espiritual, chegou até a produzir uma imagem fotográfica de uma mão invisível, que foi incluída no livro de Cesare Lombroso, Estudos sobre fenômenos hipnóticos e espíritas (1909).

Franz Kafka compreendeu com precisão o cálculo impossível que condiciona tais pessoas jurídicas. Em $O$ Processo, em $O$ Castelo, o que se evidencia é a própria natureza obscura do organismo social, cujo aparato burocrático, tecnocrático, longe de significar a eficiência e a clareza de mecanismos e processos, através dos quais é possível avançar em direção a uma solução, determina uma espécie de sujeição irrestrita a uma presença que, embora se faça sentir, permanece sempre em âmbito secreto. O local da decisão encontra-se tão inlocalizável quanto as suas razões, e, no entanto, essas decisões se apoderam invariavelmente de $K$, cujo corpo começa a sentir os seus efeitos. Judith 
Butler, em The Psychic Life of Power: Theories in Subjection, afirma que há no processo de construção mútua entre o poder e o sujeito um contrato peculiar de expropriação, segundo o qual you be my body for me, but do not let me know that the body you are is my body. An injunction and contract here are performed in such a way that the moves which guarantee the fulfillment of the injunction and the contract are immediately covered over and forgotten. Se a crescente racionalização das relações sociais serviria para exorcizar as forças misteriosas e imprevisíveis da magia, o que se constata é que mais do que a superação da magia, a ciência, a lei e a tecnologia se encontram, mais bem dizendo, em um curioso patamar de equivalência, onde as discussões giram em torno da forma moderna em que o poder pode ser exercido por um indivíduo ou uma associação sobre um outro, além do tipo de contrato, lei e ética possível de ser determinada a partir disso.

Talvez não seja estranho considerar, então, que a literatura tenha não apenas transformado a hipnose em matéria de suas narrativas, atribulações de seus personagens - lembremos aqui da verdadeira obsessão de Edgar Allan Poe pelas ciências mesméricas -, mas também reivindicado para si o direito de colocar-se no entroncamento dessas questões médicas e jurídicas, propondo a literatura como resultado direto de efeitos hipnóticos. É com este intuito investigativo que Andriopoulous escolhe para o seu epílogo o tema da escrita automática e nos lembra de que André Breton, em uma nota de rodapé de seu "Manifesto do Surrealismo", procurou delimitar um lugar especial para a literatura surrealista: Seja-me permitido ter algumas reservas sobre a responsabilidade em geral e sobre as considerações médicolegais que presidem à gradação da responsabilidade de um indivíduo: responsabilidade inteira, irresponsabilidade, responsabilidade limitada, por difícil que me seja admitir o 
princípio de uma culpabilidade, gostaria de saber como serão julgados os primeiros atos delituosos de cujo caráter surrealista não possa haver dúvida. O acusado será absolvido, ou apenas beneficiado de circunstâncias atenuantes? É pena que os delitos de imprensa não sejam mais reprimidos, pois logo viríamos assistir a um processo desse gênero: o acusado publicou um livro que ofende a moral pública; pela queixa de alguns de seus "mais honrados" concidadãos, ele é também inculpado de difamações; fizeram contra ele toda espécie de acusações pesadas, ofensa ao exército, incitação ao assassinato, à violação, etc. O acusado, aliás, fez acordo com a acusação para "amortecer" a maior parte das ideias expressadas. Limita-se em sua defesa a afirmar que não se considera autor de seu livro, não podendo este passar senão por uma produção surrealista, que exclui toda questão de mérito, ou de demérito de quem o assina, que ele se limitou a copiar um documento sem dar sua opinião, e que ele é pelo menos tão estranho quanto o presidente do Tribunal ao texto incriminado. O autor imaginado por Breton, portanto, defenderia-se das acusações como o jovem Thomas McDonald no Kansas no início desta parte, apelando ao seu estado hipnotizado durante o ato (de criação, neste caso). No entanto, diferente de McDonald, não há a quem atribuir a possessão corpórea que leva à escrita, o que sugere que o autor é resultado de uma teoria da ficção.

Não menos interessante seria considerar os procedimentos discursivos mobilizados pela indução hipnótica, que frequentemente passam pela repetição, pelo uso de imagens e dispositivos narrativos e pela escolha de um tom e ritmos apropriados para a voz de modo conformar-se o ato performativo da sugestão. Pensada desta forma, a literatura ganha vida tanto como efeito da hipnose, mas também como fonte de hipnose. Kant, em Sonhos de um visionário, dedica muitas páginas à crítica da popularização dos romances góticos e suas histórias de fantasmas e aparições 
espectrais; a sua preocupação está no furor literário decorrente dessas leituras que faz com que alguns absurdos encontrem aceitação até mesmo, como ele diz, entre pessoas racionais. No entanto, de modo diferente de Breton, Kant procura fortalecer a concepção de autor, buscando desfazer-se da responsabilidade sobre os efeitos nãointencionais de suas ideias. As advertências contra os perigos da leitura se estendem, portanto, ao seu próprio texto: levando em conta a concepção ideal, é possível que alguns de meus leitores também estejam esperando, e eu lamentaria muito se algo lido por eles viesse a Ihes causar uma impressão forte demais. Entretanto, como os alertei desde o começo, eu me eximo de qualquer responsabilidade e espero que as aberrações que sua imaginação fértil possa dar à luz, em consequência desta circunstância, não sejam imputadas a uma culpa minha. Neste momento, então, Kant percebe, à revelia de seus intentos em expurgar de sua obra qualquer força espectral, que o seu texto invariavelmente toma parte na imprevisibilidade dos jogos de sentido, não podendo livrar-se das marcas da própria mídia que critica. 
Nada sabemos do que venha a ser o peso mas apenas alguma coisa a respeito do peso dos corpos. (Jacob Von Uexküll)

Se é possível escanear o ultra-espaço e o intra-espaço é porque a tecnologia privilegia a extensão da visão ao longo dos vastos territórios sobre os quais o ser humano tem fincado as suas bandeiras. A expressão "a se perder de vista" não teria mais a mesma eficácia; o seu equivalente em inglês, "as far as the eye ${ }^{13}$ can see", passa a se referir a quase tudo. $\mathrm{O}$ olho chegou em toda parte, dotado da capacidade de ajustar a escala, o contraste e a cor daquilo que se quer tornar visível. Donna Haraway: Vision in this technological feast becomes unregulated gluttony; all perspective gives way to infinitely mobile vision, which no longer seems just mythically about the god-trick of seeing everything from nowhere, but to have put the myth into ordinary practice. And like the god-trick, this eye fucks the world to make techno-monsters. ${ }^{14} \mathrm{E}$ se o ser humano pudesse não só triar, mas matar com o olho - um olho que nunca pisca? ${ }^{15} \mathrm{Em}$ outras palavras: e se esse olho tivesse um dedo no gatilho? $Y$ ahí, en esas alturas, comenzó a escribir un poema en el cielo. O anjo da história é um anjo caído. Reerguido por um drone, ele agora percorre os céus novamente. A esse drone chamamos de progresso.

A pergunta o que a literatura tem a ver com um drone? - que pode também vir em forma de acusação: o que pode a literatura ter a ver com um drone? - é,

\footnotetext{
${ }^{13}$ É interessante também pensar que em inglês há homofonia entre "eye" e "I", o eu como a medida de todas as coisas.

${ }^{14}$ Um dos sistemas de segurança desenvolvidos pelo Departamento de Defesa americano, por exemplo, se chama ARGUS-IS (Autonomous Real-Time Ground Ubiquitous Surveillance Imaging System), aludindo a Argos Panoptes, o gigante com cem olhos

${ }^{15}$ Sobre o sonho militar, mas também capitalista, do ser humano que nunca dorme, ver 24/7: Capitalismo tardio e os fins do sono, de Jonathan Crary.
} 
evidentemente, bastante plausível. W. G. Sebald tem uma série de palestras, chamadas "Air War and Literature", que poderiam servir como pista, mas ali está bastante claro que a literatura, ou pelo menos a literatura alemã após a segunda guerra mundial, quis de todas as formas desassociar-se dos bombardeios aéreos. Uma foto tirada em Israel em 2006 pode, talvez, elucidar a questão e restaurar algum tipo de esperança para o rumo deste texto. A cena é atroz e não por isso menos complexa: crianças israelenses escrevem mensagens com canetinhas coloridas em mísseis destinados ao território libanês - "To Nasrallah, with love". BUENA SUERTE PARA TODOS EN LA MUERTE, leí con dificultad. Apesar do horror, tudo, é claro, parece apontar para a inocência dessas crianças. Além do fato inassimilável de serem crianças, é necessário também constatar que não serão elas a enviar a mensagem, a detonar o explosivo. Também não será Sayyid Hassan Nasrallah a receber a mensagem que, certamente, ficará pelo caminho - e nesse caminho, não podemos nos enganar, há gente. A cena toda vai se construindo de modo a separar cada vez mais a inscrição da mensagem das ações - isto é, da destruição - que a seguem, e a espiral das leituras possíveis se desenha para fora, rodeando a cena da escrita em círculos, cada vez mais longe, uma lista de poréns - os pais, o circo midiático, as crianças-soldados do Hezbollah, a guerra. No que constituiria esse modo de enunciação particular? De alguma forma, não seriam os mísseis lançados, pelo menos dentro de certo regime discursivo, em nome de sua defesa, da defesa daquelas crianças - em nome daqueles que não podem responder pelo que dizem? Un poeta, dije yo. Una persona educada, sí, dijo Norberto. Não é sempre isso que está em jogo quando adentramos o lugar perverso constituído pelo "em nome de"? O slogan Not in my name, bastante comum nas manifestações contra a guerra no Iraque, parece apontar para algo 
nessa direção. E quanto àqueles que não estão em condições nem de afirmar-negar: não em meu nome?

Mas eu disse que falaria aqui sobre drones e o drone é um olho armado com um dedo no gatilho acoplado a um corpo sentado a milhares de quilômetros de distância em uma sala com ar-condicionado nos arredores de Las Vegas, onde além de luzes há artistas cover, entre os quais soldados que matam sem ir para a guerra. $\mathrm{O}$ absurdo da situação torna possível uma formulação alternativa à pergunta acima: em que pode um drone se parecer com a literatura? A pergunta também pode parecer absurda, inclusive pelo desconforto que gera, ao sugerir que haveria algo de literário em um drone, porque conceder estatuto especulativo - a chance de se apresentar como aquilo que não é - a uma máquina de guerra, embora possível, talvez seja pouco estratégico ${ }^{16}$, mas acontece que nem toda literatura é ficção, nem toda ficção é não-real, e assim por diante.

Na vídeo-instalação "5,000 Feet Is the Best", de Omer Fast, um ex-operador de drones no Afeganistão e no Paquistão descreve porque cinco mil pés é a melhor altura para voar. Podía pilotar sin problemas un Hawker Hunter o un helicóptero de combate, pero lo que más le gustaba era coger el viejo avión cargado de humo, remontar los cielos vacíos de la patria y escribir con letras enormes sus pesadillas, que también eran nuestras pesadillas. A sua voz é sobreposta à imagem (filmada por um drone) de um menino andando de bicicleta no que, a julgar pelo deserto, parece ser um subúrbio de Las Vegas. O descampado árido do início da filmagem por um momento indica a possibilidade desse menino ser um menino qualquer afegão, mas logo a bicicleta chega a um bolsão residencial com cercadinhos brancos e piscinas, e as coincidências,

\footnotetext{
${ }^{16}$ Uma questão importante a ser colocada, por exemplo, ao documentário "The Act of Killing", em que genocidas da Indonésia são convidados a dirigir o seu próprio filme e reencenar cenas de assassinato e tortura.
} 
evidentemente, acabam - o drone que filma esse menino branco de mochila não se chama Reaper ou Predator. 5000 thousand feet is the best. At 5000 thousand feet I can tell you what type of shoe you are wearing from a mile away. I can tell a person's clothes, beard, hair color. We have the IR infrared which you can switch to automatically and that'll pick up any heat signature or cold signatures. I mean if someone sits down let's say on a cold surface for a while then gets up you'll still see the heat from that person for a long time. Allí mismo escribió el primer verso: La muerte es amistad. It kind of looks like a cold blossom shining up in heaven. Después planeó sobre unos almacenes ferroviarios y sobre lo que parecían fábricas abandonadas y escribió el segundo verso: La muerte es Chile. It's quite beautiful. Allí, sobre La Moneda, escribió el tercer verso: La muerte es responsabilidad. I mean if someone lights up a cigarette, that's a huge beacon you see, you just see a very white glow coming from that area and you could be following them and they won't see you or hear you. En el camino de vuelta al aeródromo escribió el cuarto y quinto verso: La muerte es amor y La muerte es crecimiento. A intimidade que o operador de drone desenvolve com seus potenciais alvos é desconcertante, porque é invasiva e destrutiva e também porque o operador nunca poderá ver a vítima vendo-o matá-lo, os olhares nunca se cruzam. It's quite beautiful: seria o caso de discutir - de desautorizar - a beleza em questão ${ }^{17}$ É a possibilidade de estetizar a violência que aproxima o drone da literatura, um flâneur homicida dos céus? Há, porém, algo mais: a guerra dirigida pelos UAVs (Unmanned Aerial Vehicles) coloca

\footnotetext{
17 Sebastião Salgado, em The Salt of the Earth, sobre ter que ir embora do campo de petróleo Burgan, completamente em chamas: foi uma dor no coração abandonar um espetáculo tão grandioso. Karlheinz Stockhausen sobre o ataque de 11 de setembro às torres gêmeas: the greatest work of art that is possible in the whole cosmos (...) you have people who are so concentrated on one performance, and then 5000 people are dispatched into eternity, in a single moment. I couldn't do that. In comparison with that, we're nothing as composers.
} 
em prática a possibilidade de ver sem ser visto e, principalmente, de matar sem morrer - uma situação, em suma, de não-resposta absoluta. Entonces, en el otro extremo de Santiago cayó el primer rayo y Ramírez Hoffman escribió: La muerte es limpieza. Se o drone não responde por si, não há como responder a ele. Mais do que qualquer situação de desigualdade em um conflito, o que a guerra por drones instaura como política é a neutralização de toda possibilidade de reação. Em outras palavras, não é tanto que a guerra por drones desarticula de modo preciso, eficiente e veloz qualquer chance de contra-ofensiva, mas a contra-ofensiva é reduzida desde o início à cena patética de atirar para o céu às cegas, sabendo que não há ninguém lá. Then we do something called the 'light of God' - the marines like to call it the 'light of God' - it's a laser-targeting marker. Escribió, o pensó que escribió: La muerte es mi corazón. We just send out a beam of laser and when the troops put on their night-vision goggles, they'll just see this light that looks like it's coming from heaven, pfft, right on the spot. Y después: Toma mi corazón. Coming out of nowhere from the sky. It's quite beautiful. Cuando avistó el aeródromo escribió: La muerte es comunión.

Não é sem motivos, dirá Benjamin Noys em "Drone Metaphysics", que a imagem de Deus é retomada de novo e de novo no universo discursivo dos drones. Segundo o autor, os UAVs codificam certo discurso teológico e corporificam desejos de transcendência - um operador de drone teria dito certa vez: sometimes I feel like a God hurling thunderbolts from afar. Claro, há instantaneidade, imediatez, onipotência e onividência. Noys diz que os drones carregam consigo não apenas munição, mas também uma promessa metafísica, uma convergência entre o militarismo e a metafísica: uma forma particular de um sujeito sem sujeito. Então, ainda que os drones não sejam completamente automatizados, isto é, ainda que existam seres humanos participando 
do que Noys chama de "the kill chain", possibilitando locais de intervenção política, these humans are constituted in ways to make them resist calls on their humanity and they are called to conform to the drone. Adorno's prescient insight confirms that the achievement of 'subjectlessness' is not simply the effect of automation, but a labour by the subject that operates on itself in the process of self-automation, or the creation of an 'automatic self'. Há o que ele chama de uma semelhança ao ódio que os gnósticos têm da matéria. ${ }^{18}$ Esse gnosticismo militar, ele diz, defende que a alma poderosa é desterritorializada, fluida e transferível, ao passo que a alma fraca está presa no corpo e no mundo. This is to challenge certain discourses of 'acceleration' that regard resistance as lying in a capacity of excess, the friction-less, hypertrophy, and so forth that are claimed to outpace the forms of military, state, and capitalist power. The desire for a final deterritorialisation that can slip into a smooth space of resistance is not only unfaithful to Deleuze and Guattari's warning '[n]ever believe a smooth space will suffice to save us', but also remains within the field of drone metaphysics.

A pergunta, então, finalmente pode se estabilizar na seguinte conformação: o que acontece quando do outro lado não há um corpo? - uma pergunta que simultaneamente implica outra: o que acontece quando do outro lado há um corpo que não pode morrer? Uma forma de intervenção remota que, diferente da hipnose, prescinde de um corpo mediador. $\mathrm{O}$ drone como uma máquina produtora de um estado de exceção móvel que se instaura onde quer que seja, incondicionalmente, isto é, sem

\footnotetext{
18 O futurista italiano Fedele Azari, lança do céu, em 11 de abril de 1919, o manifesto intitulado II Teatro Aereo Futurista, uma defesa de um modo de conceder liberdade às palavras, escrevendo-as no céu de modo a constituir uma forma de expressão, segundo ele, verdadeira, absolutamente livre, viril e enérgica que conduziria à grande nação futurista. Ele diz: HO ESEGUITO IO STESSO, NEL 1918 [durante a guerra, portanto], MOLTI VOLI ESPRESSIVI E SAGGI DI TEATRO ELEMENTARE SUL CAMPO DI BUSTO ARSIZIO. HO constatato como sia facil per gli spettatori seguire tutte le sfumature di stati d'animo dell'aviatore, data la identificazione assoluta tra il pilota e il suo apparecchio, che diventa come un prolungamento del corpo: le ossa, i tendini, i muscoli e i nervi si prolungano nei longheroni e nei fili metallici.
} 
que nada o condicione, a partir do qual é possível erigir, por exemplo, muros invisíveis ou por meio do qual é possível implementar procedimentos extrajudiciais que tornam prisões como Guantánamo obsoletas. Pensando nas leituras de Derrida a respeito de Walter Benjamin ${ }^{19}$, torna-se bastante difícil não ler a primeira tese em "Sobre o conceito da história" com algum pesar diante da aposta eufórica no autômato invencível que é, em verdade, um ciborgue com ares messiânicos a vencer as guerras feudais do tabuleiro de xadrez.

Em Teoria do drone, de Grégoire Chamayou, há uma discussão interessante a respeito das semelhanças e diferenças entre kamikazes e drones ${ }^{20}$. Ambos são bombas com olhos; o primeiro tem como arma o corpo, o segundo é uma arma sem corpo. 0 drone, no entanto, é visto, geralmente, como uma arma moralmente superior, promovedora de uma morte mais higiênica, noção curiosa já que a única vida que ela preserva é de quem comete o ato de matar. Interessante cálculo este, em que é mais digno o algoz não morrer com a vítima do que partilhar do mesmo destino, um afastamento absoluto do sacrifício como discurso primeiro da guerra. Em ambos os casos, o horror dos métodos empregados parece estar situado na exclusão a priori de qualquer esboço de resposta: o suicida-homicida por perpetrar simultaneamente crime e punição; o tele-homicida por, apesar da dissolução da premissa do combate - a mesma

\footnotetext{
${ }^{19}$ Derrida, em "Force of Law", lê o texto de Benjamin, "Para uma crítica da violência", em uma chave perturbadora, talvez até injusta. Centralizando sua análise em torno da distinção feita por Benjamin entre a violência mítica (aquela que funda a lei) e a violência divina (aquela que destroi a lei, a aniquila em sua própria origem), Derrida faz uma pergunta sobre qual pensamento de Benjamin estaria já virtualmente formado ou articulado nesse ensaio sobre o tema da solução final.

${ }^{20}$ Uma das armas seriamente cogitada (e testada inúmeras vezes) para a destruição do Japão após Pearl Harbor foi uma bomba incendiária desenvolvida pelo exército americano que consistia em bombas amarradas a morcegos. A ideia era que os morcegos, soltos desde aviões, auxiliados na descida por paraquedas, alojariam-se nos forros de madeira das construções japonesas, e as bombas acopladas seriam detonadas por timers. Em um dos testes, os morcegos escaparam e explodiram uma base de testes do exército americano. Um manual de artilharia do século XVI, escrito por Franz Helm, já sugeria explosivos amarrados a pombos e gatos.
} 
chance de morrer que de matar -, ter sua atividade enquadrada dentro da normalidade da guerra. No caso do drone, o paradoxo é que, em rigor, com tal autonomização da decisão letal, o único agente humano diretamente identificável como sendo a causa eficiente da morte seria a própria vítima, que terá tido a infelicidade, pelos movimentos inapropriados de seu corpo, como já era o caso com as minas antipessoais, de detonar sozinha o mecanismo automático de sua própria eliminação.

Depois de passar por toda uma discussão sobre a teoria do estado e da soberania, explorar as fases distintas do contrato social, desde Hobbes, segundo o qual o soberano protege a população em tempos de paz, ao passo que em tempos de guerra é a população que protege o soberano, Chamayou chega à relação entre o welfare state e o warfare state. $\mathrm{O}$ estado de bem-estar social surge como consequência do grande contingente de soldados mobilizados em guerras, cuja lacuna social deveria ser apaziguada de alguma forma. Com o declínio da garantia de estabilidade socioeconômica, seria preciso buscar formas de fazer guerra que não passassem pelo alto dispêndio de vidas. Sugere-se, portanto, que a dronização é um fenômeno que serve como contraponto à precarização da vida em geral. No entanto, o efeito estrutural dessas mutações do modo de guerra é, em realidade, uma precarização mais profunda das formas de vida, pois ao reduzir-se a dependência material do aparelho de Estado para com o trabalho militar, e por meio disso sua dependência social para com os corpos que constituíam essa força de trabalho, os corpos tornam-se prescindíveis, assim como os mecanismos que proporcionariam a esses mesmos corpos uma vida mais digna. A desestabilização do contrato social por meio da dronização desativa a possibilidade de postura crítica daqueles que estariam colocando seus corpos em risco, ou seja, desmonta qualquer possibilidade de protesto que tenha como local de enunciação o 
próprio corpo a ser colocado em combate (pensemos aqui, por exemplo, na guerra do Vietnam). Chamayou diz que se as democracias liberais desenvolvem síndromes "de aversão pelas perdas", não é porque, como se acredita, elas atribuem um valor por demais elevado à vida de seus cidadãos, mas, ao contrário, porque já não dispõem senão de um conceito muito pobre do que é a vida, segundo a qual preservar a vida física prevaleceria a qualquer preço, mesmo em detrimento da natureza dos meios empregados, sobre a salvaguarda de uma vida ético-política superior a esta. Se essa provocação leva à reflexão sobre a ausência de condições da vida que se diz proteger, por outro lado assemelha-se perigosamente ao discurso necropolítica, segundo o qual se mata em nome de um conceito muito pobre do que é a vida e sobre a salvaguarda de uma vida ético-política superior, pensemos por exemplo na advogada que foi demitida da rede de notícias CBS após escrever em rede sociais que não sentia nenhum tipo de simpatia pelas vítimas do tiroteio em Las Vegas pois, segundo ela, fãs de música country seriam todos republicanos portadores de armas.

Na cidade de Madrid, em abril de 2015, houve o primeiro protesto holografado de que se tem notícia, em que as pessoas poderiam, desde suas casas, retransmitir sua imagem a ser holografada na frente do parlamento espanhol, em resposta à lei de 2013 que impedia a congregação de pessoas diante de prédios governamentais sem autorização prévia. Mais do que propor uma nova era do protesto, em que a hiperconectividade, aliada às tecnologias de imagem, viriam a suplantar a presença corpórea dos protestos, estava posta em cena a situação inusitada em que as imagens das pessoas pareciam ter mais direitos de trânsito do que as pessoas em si e o corpo era impedido de manter sua posição ativa no fazer político, algo como a transformação e redução da política a uma telepresença. Em Notes Toward a Performative Theory of 
Assembly, Judith Butler parte do pressuposto de que os significados políticos de corpos reunidos não podem se reduzir àqueles colocados em cena pelo discurso. Ainda que nem todo mundo possa aparecer em forma de corpo, ações corporificadas podem significar de maneiras que não são estritamente discursivas ou pré-discursivas e é nesse sentido que a liberdade de reunião e a liberdade de expressão constituem-se como garantias distintas, o que quer dizer que uma pode existir sem a outra. We might be tempted on the basis of older habits to say, "but if it (the body) signifies, it is surely discursive", and maybe that is true. But that rejoinder, even if it holds, does not let us examine that important chiasmic relation between forms of linguistic performativity and forms of bodily performativity. They overlap; they are not altogether distinct; they are not, however, identical with one another.

Chamayou, via Hannah Arendt, sugere que é o próprio fato do Estado necessitar do corpo de seus cidadãos, até mesmo os Estados mais autoritários, que o impede de ser pura violência - o poder como sujeição dos corpos. A dissolução desse pacto - que mais bem é uma chantagem - pela substituição da produção e da guerra por autômatos coloca os corpos em situação de vulnerabilidade, pois o poder pode reverter-se em pura violência, os drones utilizados contra a própria população, mas, por outro lado, reciprocamente, é também possível imaginar que sem a mobilização de corpos por parte do Estado, ficamos mais próximos da dissolução do poder: da mobilização dos corpos contra o Estado, reduzido a um aparelho. Mas talvez não seja possível ser tão otimista: onde está, hoje, o sujeito do poder? Esse sujeito está precisamente em qualquer lugar em que ele se empenhe ativamente para se fazer esquecer. É inclusive essa intensa atividade de apagamento de si mesmo que o anuncia inevitavelmente. Toda uma agitação subjetiva, com esforços e investimentos enormes, para confundir as pistas, 
apagar os rastros, escamotear qualquer sujeito discernível da ação, com o fim de travestir essa ação em puro funcionamento, uma espécie de fenômeno natural, dotado de um tipo de necessidade similar, só que dirigido por administradores de sistemas que vez por outra corrigem seus bugs, efetuam atualizações e regulam os acessos. Se a política passa necessariamente pelo corpo, pelos corpos em corpo a corpo, talvez a possibilidade de comparecer à cena da disputa seja insuperável para qualquer ação que se pretenda ética, em que o poder sobre os corpos passa para uma política dos corpos, com os corpos, pelos corpos, para os corpos. Se os drones agem, segundo a propaganda oficial, preventivamente, monitorando alvos e ligações de celular, compondo um arquivo extenso por meio do qual se constroem genealogias do mal, eliminando os tentáculos para tentar chegar até a raiz, não é nem possível mais dizer que há um crime subjacente ao inimigo; ou seja, de acordo com a nomenclatura schmittiana de guerra, não há amigo ou inimigo, não há guerra, só há mesmo assassinato, corpos vigiados, arbitrariamente julgados e sentenciados com o auxílio de algoritmos que processam dados, encurralados em um visor de alta precisão para, finalmente, serem derrubados, corpos cujos enterros são então assistidos em Las Vegas para a obtenção de mais dados, que voltam a alimentar as bases de dados. Uma chacina articulada eminentemente por códigos, e que se vale de suas elaboradas equações para reivindicar-se humanitária, o que no fundo só revela o delírio subjacente àquilo que se afirma como uma necroética empregada em prol do bem da humanidade em geral, data crunchers não-humanos mais humanos que os humanos. Como disse certa vez Eduardo Viveiros de Castro: ou o pós-humanismo é menos que o humano, ou ele não é ${ }^{21}$. Ao contrário do que sugerem os roteiros de ficção científica, o perigo não é que os robôs comecem a desobedecer; é

\footnotetext{
${ }^{21}$ Ou plus d'un, nos rastros de Derrida, sempre ao mesmo tempo mais que um, menos que um.
} 
precisamente o inverso: que nunca desobedeçam, que não haja possibilidade de insubmissão.

\section{$/ / /$}

Arremessado de 5000 pés de altura, um livro pode certamente matar (um livro pesado, que vencesse com facilidade a resistência do ar), mas, para além disso, talvez ainda seja possível argumentar que o paralelo entre a literatura e o drone é descabido.

\section{Algunos oficiales y algunas señoras comentaron lo raro que resultaba aquel piloto}

poeta. Ainda assim, também não seria impossível argumentar que a literatura mata, à sua forma, ou se alia a métodos de morte, su paso por la literatura deja un reguero de sangre y varias preguntas realizadas por un mudo: a leitura que eu sugiro é transversal, não tanto uma analogia, mas uma investigação sobre a ausência de um corpo que possa responder pela violência perpetrada - a invencibilidade garantida pela imunidade. Derrida, em Passions, e também em This Strange Institution Called Literature, diz da literatura como aquilo que tem o direito absoluto à não-resposta, isto é, podendo dizer tudo, não precisaria responder a nada; não precisa responder por nada - uma conformação ética peculiar, que, se por um lado, resiste ao perigo sempre iminente da censura, por outro torna-se porto seguro para qualquer tipo de pensamento e expressão, absolutamente imune a qualquer pergunta, pensamentos e expressões, inclusive, dos quais nos tornamos, de certa forma, cúmplices enquanto leitores que assumem o eu da narrativa. ${ }^{22}$

\footnotetext{
${ }^{22}$ Segundo Alexandre Nodari, no texto "A literatura como antropologia especulativa", o autor se objetiva, se obliqua em narrador, em personagens, em heterônimos, etc.; $e$, por sua vez, o leitor se subjetiva naqueles que, num texto literário, dizem eu. Além disso, está em jogo na fiççoo, como argumenta Milan Kundera, a exploração de um território novo da existência por meio de "egos imaginários", alter-egos: "o romance não examina a realidade, mas sim a existência. A existência não é o que aconteceu, a existência é o campo das possibilidades humanas, tudo aquilo que o homem pode tornar-se, tudo aquilo de que é capaz. Os romancistas desenham o mapa da existência descobrindo esta ou aquela possibilidade humana."
} 
Voltemos a André Breton e a seu hipotético tribunal, onde o autor e o juiz teriam a mesma responsabilidade - isto é, nenhuma - pelo texto; para Foucault é o próprio tribunal que dá origem à noção de autoria, primeiro contra a heresia, no final da Idade Média, depois em favor da propriedade privada dos direitos autorais, com o advento da imprensa. A dissolução do autor como origem é a dissolução ou a inoperância do tribunal e é por isso que Breton, de modo nostálgico, lamenta que já não haja tantos processos, nos quais poderia colocar em marcha essa inoperância por meio da escrita surrealista. É como se legitimar o surrealismo dependesse de deslegitimar a autoridade do autor. Por outro lado, também, talvez fosse possível dizer que o lamento de Breton tivesse a ver com o reconhecimento de certa neutralização da literatura, processo que já não a tornava digna de um tribunal e diante do qual o autor, portanto, já não tinha a mesma importância - uma desimportância distinta daquela buscada por Breton. Em 1968, Barthes decreta a morte do autor: a escritura é esse neutro, esse composto, esse oblíquo pelo qual foge o nosso sujeito, o branco-e-preto em que vem se perder toda identidade, a começar pela do corpo que escreve. É a saída de cena do corpo do autor, uma dessubjetivação mediada pela escrita, um reconhecimento da contingência da escrita, da contingência daquilo a que nomeamos sujeito. Embora ambos coincidam no fato de que o autor não existe como origem da literatura, os argumentos de Breton são distintos aos de Barthes na medida em que para Breton o corpo do autor é mero mediador de forças ocultas enquanto que para Barthes já não há corpo ${ }^{23}$. Na concepção

\footnotetext{
${ }^{23}$ A psicografia coloca uma exigência dupla diante da noção de autoria, segundo pondera Alexandre Caroli Rocha em sua tese de mestrado sobre Parnaso do Além-Túmulo. Se, por um lado, reforça a ideia da autoria, que se estenderia para além do mundo dos viventes, por outro lado deflagra a sua instabilidade na figura do médium que a atualiza no mundo material.
} 
foucaultiana, o nome do autor também não está atrelado propriamente a um indivíduo real e exterior que proferiu um discurso, mas remete a um certo tipo de discurso com estatuto específico. Quando Breton fala em uma gradação de responsabilidade, das acusações feitas pelos tribunais, o interesse dele não parece ser, a princípio, refutar as acusações nos termos mesmos da acusação, mas simplesmente inviabilizá-las por meio da supressão de um ator consciente de seus atos. O que Barthes propõe, no entanto, é também uma sobrevida ao tribunal, ou uma proposição que deixa espaço para outro tipo de tribunal, ao transferir o poder aos leitores e a cadeira de réu para o sentido. Capitu traiu ou não traiu? A obra de Monteiro Lobato é racista ou não? Descreve ou prescreve? Se a linguagem não pertence a ninguém, isto é, se o seu local não está previamente designado, ela é infinitamente apropriável, o que equivale a dizer que ela está sempre sob disputa - sua significação sempre à beira da totalização - e que essa disputa não é interna à linguagem, embora seja imanente à sua condição. Mantê-la deslocada de seu próprio lugar, ou seja, sem que ela se torne vulnerável a si própria, portanto, seria mantê-la em disputa ou, ao menos, defendê-la como disputável, reconhecendo simultaneamente sua fixidez e o seu ponto de fuga. Propor, por exemplo, que um texto não pode ser racista não significa que ele não possa também ser racista. Esse movimento, porém, faz com que a imunidade passe do autor ao sentido - um sentido pelo qual nunca é possível responder, pois não há prova final. Como ter certeza de que tal movimento também não se torna um método universal em que a literatura engendraria a diferença a priori, em uma espécie de Deus É Amor, onde ela também seria a sua própria garantia e, portanto, diante da qual seria impossível se posicionar, sobre a qual seria impossível decidir? E o que dizer do risco, se o risco é sempre do outro? 


\section{//I}

Em Point Omega, de Don Delillo, um livro em que a violência parece nunca de fato irromper - embora seja possível intuí-la o tempo todo -, formas distintas de anonimato se delineiam pela impossibilidade de nomear a violência como tal e, consequentemente, pela impossibilidade de encontrar culpados. As partes "Anonymity 1" e "Anonymity 2" abrem e fecham o livro, respectivamente, em uma cena de exibição de uma vídeo-instalação de Douglas Gordon no Moma, 24 Hour Psycho, em que as 1h49m do filme Psycho, de Alfred Hithcock, são expandidas para o período de vinte e quatro horas, a dois frames por segundo. Durante a cena famosa do assassinato de Marion Crane, pela lentidão da ação, os aros da cortina transformam-se em personagem principal da ação fílmica, desfazendo o suspense e o terror, e perdendo-se de vista o ponto de origem da ação, like watching the universe die over a period of about seven billion years, o que talvez até invalide a pergunta: quem é o assassino? ao mesmo tempo em que coloca outra: quem é responsável pelo fim do universo? Não que a revelação final em Psycho fizesse muita diferença; que ela também por si só já não invalidasse a pergunta, pois o que se irá afirmar, segundo o parecer final do psiquiatra Dr. Fred Richmond, é que Norman Bates, o assassino, é e não é Norman Bates. O que é mais notável, de todo modo, é que ninguém lembra o nome de Marion Crane. O narrador desta parte diz: everybody remembers the killer's name, Norman Bates, but nobody remembers the victim's name. Anthony Perkins is Norman Bates, Janet Leigh is Janet Leigh. The victim is required to share the name of the actress who plays her, uma observação que aponta para as dinâmicas de poder em que a vítima não pode ser nada além disso e o opressor pode habitar elusivamente o universo dos significados. Derrida, em "Racism's Last Word”, descrevendo um movimento contrário a este, sugere que a 
palavra "apartheid" não teria sido traduzida para nenhuma outra língua, pois nenhuma outra língua teria querido hospedá-la, condenando-a a ser idêntica a si.

No livro há um personagem, Roger Elster, um intelectual que auxiliou a inteligência do exército americano na guerra do Iraque, trabalhando no Pentágono com the metaphysicians in the intelligence agencies e the fantasists in the Pentagon e agora, aposentado, busca um descanso no deserto para reclaim his body. Acompanhado por Finley, um jovem diretor de cinema que deseja fazer um documentário sobre ele, discorre sobre a sua função na guerra e os seus desejos. Elster passa os dias no deserto lendo Pound e Rilke. A descrição de sua função é vaga: we tried to create new realities overnight, careful sets of words that resemble advertising slogans in memorability and repeatability. These were words that would yield pictures eventually and then become three-dimensional. Mais peculiares ainda são as circunstâncias da contratação de Elster, convidado ao seu posto de trabalho após a publicação de um trabalho acadêmico chamado "Renditions". O título é significativo porque durante a guerra no Iraque as "extraordinary renditions", em que suspeitos eram levados a territórios onde as leis de interrogação eram mais relaxadas ou inexistentes para que tortura fosse realizada, foram empregadas à exaustão em nome da guerra ao terror. Mas não é esse o assunto de Elster em seu texto, e ele é acusado de não fazer menção ao ato criminoso e à culpabilidade; no lugar disso há um estudo da palavra "rendition", com referências às suas diversas etimologias e usos. Word origins and covert prisons. Old French, Obsolete French and torture by proxy. The essay concentrated on the word itself, earliest known use, changes in form and meaning, zero-grade forms, reduplicated forms, suffixed forms. There were footnotes like nested snakes. But no specific mention of black sites, thirdparty states or international treaties and conventions. O diretor de cinema se pergunta 
o que Elster pensava da acusação de que ele havia tentado encontrar mistério e romance em uma palavra que estava sendo usada como um instrumento de segurança nacional, a word redesigned to be synthetic, concealing the shameful subject it embraced? Talvez por isso seja curioso quando, refletindo sobre a guerra falida no Iraque, e desejando uma outra versão da mesma guerra, Elster diz: I wanted a haiku war. I wanted a war in three lines. Haiku means nothing beyond what it is. This is the soul of haiku. Bare everything to plain sight, ou seja, uma guerra que significasse apenas exatamente o que ela significava. Elster não é contra a guerra, mas ele afirma desejar uma guerra melhor, em que as coisas são o que elas são, but in those rooms, with those men, it was all priorities, statistics, evaluations, rationalizations. Mas ali no deserto Elster está envolvido em outra guerra, uma guerra contra o tempo, aguardando a chegada do ponto ômega, o ponto final de convergência final do universo, the dream of extinction. Uma bomba nunca é o suficiente, ele argumenta, e o ponto ômega, portanto, passa a ser a realização do seu desejo genocida. Back now to inorganic matter. This is what we want. We want to be stones in a field.

Enquanto transcorrem as conversas sobre a guerra, a filha de Elster, Jessie, também chega à casa no deserto, com o intuito de esconder-se de um relacionamento abusivo com um homem em Nova Iorque. Mas ali ela também tem dificuldades em encontrar um espaço seguro, tendo seu espaço invadido por Finley, que, obcecado, aparece na porta do seu quarto uma noite, abre-a um pouco mais e a olha ali, apesar de não ter tido qualquer tipo de sinal afirmativo em nenhuma de suas tentativas prévias, para perceber então que ela o vê olhando para ela. Em outros momentos, Finley a observava de longe, I found it disturbing to watch her, knowing that she didn't feel watched. Neste dia em que ela o vê, Jessie vira para o outro lado e se cobre com o lençol 
até o pescoço. No dia seguinte ela desaparece. Não fica claro se ela é assassinada, se pelo homem de Nova lorque, cujo nome não sabemos ao certo, mas que muito possivelmente se chama Dennis, ou se ela desaparece voluntariamente do mundo, como o seu pai, que se pergunta: Do we have to be human forever?, com a diferença de que o seu pai parece querer desaparecer por sentir sua consciência pesar pelos rumos da guerra, ao passo que Jessie parece não conseguir responsabilizar ninguém pelas violências sofridas. Sabemos muito pouco de Jessie, sua voz aparece raramente, quase tudo que sabemos dela é mediado por Finley or Elster. Sua mãe, quem talvez saberia dizer alguma coisa relevante, é reduzida a uma voz no telefone. É justamente por ela que sabemos que Jessie recebia ligações constantes de um número anônimo "BLOCKED CALLER", motivo pelo qual a mãe considera importante para a filha alguns dias no deserto com o pai. Mas ali ninguém fala sobre isso, ao contrário, Elster desmerece as preocupações da mãe de Jessie, sua ex-eposa. Finley quer ficar com Jessie. Elster a vê como uma extensão de si. Não sabemos nada sobre o que ela quer, do que tem medo, se tem medo, se tem desejos. Enquanto Jessie dorme, eles conversam sobre o exagero das mulheres e dizem que são todas loucas. Quando Finley diz que é sua ex-mulher quem o considera louco, Elster responde: I don't know. What are you protecting? She's crazy. Say it.

O comando de Elster é claro: diga. Ao dizer que ela é louca, a loucura dela se torna um fato, uma admissão, uma confissão. Essa é a natureza do papel que Elster ocupou na guerra, a de quem criava realidades com palavras. Em "How to Do Things with Pornography", Nancy Bauer retoma as palestras de J.L. Austin, How to Do Things with Words, para compreender exatamente o que a pornografia faz, no sentido forte da palavra "fazer", naquilo que Austin chama de ato ilocucionário. O interesse de Bauer 
não é, portanto, apenas no efeito que a pornografia gera, naquilo que é perlocucionário, mas naquilo que seria inerente à pornografia. A sua hipótese é de que a pornografia, ou certa pornografia, como forma de expressão, mais do que dar ideias e construir uma gramática sexual em que a mulher é discriminada como objeto, transforma um "não" em um "sim". Essa diferenciação para ela é importante porque a defesa da liberdade de expressão afirma que não é possível proibir algo que não seja discriminatório em si mesmo, ou seja, algo que apenas gere discriminação por meio da intermediação e ação de outras pessoas: pornography, no matter how systematic its discriminatory effects, cannot be said to discriminate against women in and of itself and therefore must count, legally at least, as a protected form of expression. A questão é de ordem discursiva, não levando em conta as condições de produção dos filmes pornográficos, o que seria uma outra questão, ainda que bastante importante. A defesa da pornografia pelas leis de liberdade de expressão é importante para protegê-la contra acusações de obscenidade e da interdição a fantasias não-normativas. Bauer, no entanto, busca responder o que a pornografia de fato consegue fazer, em si mesma, e sugere que, além de legitimar a violência contra a mulher, portanto, certa pornografia priva as mulheres das condições contextuais que devem operar para que suas vozes sejam ouvidas. Há o que ela chama de "incapacitação ilocucionária", isto é, as mulheres, apesar de - em situações ideais poderem enunciar as palavras que querem enunciar, veem-se removidas de sua capacidade de conseguir o que querem conseguir com a enunciação. Se, portanto, os homens estão condicionados por certa pornografia a não reconhecer as palavras das mulheres como uma recusa, ela não será capaz de recusar. Certa pornografia silencia as mulheres não em suas locuções, mas em suas ilocuções, e condena-as a performar atos 
ilocucionários em um vazio em que o "não" nunca é apenas um "não" porque esse "não" é também um "sim”, uma perversão do sentido.

Na parte que fecha o livro "Anonymity 2", tudo leva a crer que a personagem diante da obra de Douglas Gordon é Jessie. "Anonymity 2" se passa exatamente um dia antes de "Anonymity 1", ambos episódios cronologicamente anteriores às semanas passadas no deserto. Ambas as partes são narradas pelo mesmo homem, que vai todos os dias a exposição assistir à exibição lenta de Psycho. Talvez seja ele o responsável pelas chamadas anônimas, o rapaz que possivelmente se chama Dennis. Ele pede o telefone dela, e ela parte. Ele retorna à exposição. Tanto este narrador, quanto Finley na parte em que é narrador, tem dificuldade em realizar leituras a respeito da reciprocidade do desejo de Jessie e, consequentemente o leitor, e inclusive a leitora, encontram também dificuldade para medir o seu desconforto, para sensibilizar-se às suas reações menos perceptíveis aos avanços de ambos os homens, respostas que não são nunca nem um não nem um sim, ou melhor, leituras masculinas de respostas que não são nunca nem um não nem um sim e, portanto, com quase toda a certeza, devem ser um sim. Não é, portanto, que a instabilidade se converta em um álibi perfeito, mas que a sua promoção a qualquer custo se torna o próprio local do crime. 
A voz que eu do céu tinha ouvido tornou a falar comigo, e disse: Vai, e toma o livro que está aberto na mão do anjo que se acha em pé sobre o mar e sobre a terra. $E$ fui ter com o anjo e lhe pedi que me desse o livrinho. Disse-me ele: Toma-o, e comeo; ele fará amargo o teu ventre, mas na tua boca será doce como mel. Tomei o livrinho da mão do anjo, e o comi; e na minha boca era doce como mel; mas depois que o comi, o meu ventre ficou amargo. (Apocalipse 10:8,9)

Em um ensaio de tom peculiar, Derrida faz uma curiosa sugestão: the breaking of the mirror would be, finally, through an act of language, the very occurrence of nuclear war. Who can swear that our unconscious is not expecting this? dreaming of it, desiring it? O ano é 1984, a guerra é fria, e o horizonte distópico não se restringe a uma sociedade totalitária, mas mais bem conjura um mundo que ruma à sua destruição total, sem restos, sob a iminência do holocausto nuclear. O ensaio, que antes fora uma apresentação oral para um colóquio organizado pela revista Diacritics, se chama "No Apocalypse, Not Now (Full Speed, Seven Missiles, Seven Missives)", e retoma, ainda que a contrapelo, as sete cartas de João no livro da Revelação. O título, que parece indicar a possibilidade de adiar o Apocalipse - isto é, não agora - é em realidade um anúncio para um fim de mundo sem revelação final. O texto começa com uma construção verbal estranha: At the beginning there will have been speed. No princípio terá havido velocidade, portanto - formulação que não permite espaço entre o começo e o fim, espaço dentro do qual o tempo presente poderia operar. Também não há brecha para especular além do fim, algo que poderia dar abertura ao tempo futuro - haverá 
velocidade e depois... - e permitiria também que o começo fosse referido em tempo passado. Eu sou o Alfa e o Ômega, diz o Senhor Deus.

Derrida está interessado em demonstrar a relação inerente entre a guerra nuclear, a desconstrução e a literatura para oferecer um esboço daquilo que poderia ser chamado de nuclear criticism, isto é, um modo em que aqueles que não são profissionais militares, estrategistas, diplomatas ou de tecno-ciências nucleares, mas especialistas em textos e discursos, possam contribuir para a discussão. O seu argumento só se sustenta na medida em que, como a guerra nuclear total ainda não sucedeu de fato - Derrida defende que as bombas em Hiroshima e Nagasaki foram lançadas para dar fim a uma guerra clássica e não para iniciar uma guerra nuclear -, ela só existe especulativamente por meio da linguagem, ou seja, a guerra nuclear total, até o presente momento, só existe como fábula. A realidade da guerra nuclear, portanto, por ora, é o referente significado de um texto ou discurso, uma invenção nos seus múltiplos sentidos, uma simulação retórica. Isto, evidentemente, não quer dizer que não há um horror real, mas aponta para a força daquilo que se considera como apenas retórico e discursivo, uma relação indelével com a guerra, diz Derrida, desde pelo menos o cavalo de Tróia. Just as all language, all writing, every poetico-performative or theoretico-informative text dispatches, sends itself, allows itself to be sent, so today's missiles, whatever their underpinnings may be, allow themselves to be described more readily than ever as dispatches in writing (code, inscription, trace, and so on). That does not reduce them to the dull inoffensiveness that some would naively attribute to books. It recalls (exposes, explodes) that which, in writing, always includes the power of a death machine. Derrida, em continuidade com sua obra filosófica, está interessado não só naquilo que a 
literatura pode oferecer em termos de sobrevivência, mas também na forma em que ela própria se constitui como uma máquina de morte.

Assim como os drones, a tecnologia nuclear depende de estruturas de informação e comunicação, estruturas de linguagem e códigos; não apenas a isso, porém, se limita a sua relação com a literatura. Distinguindo a literatura da poesia, da épica e das belle-letres em geral, Derrida determina a constituição da literatura como dependente, em primeiro lugar, da construção de um arquivo que se soergue e existe mais além da tradição oral, e, em segundo lugar, do direito positivo que legisla sobre direitos autorais e, assim, identifica um signatário, um corpus, um nome, um título e realiza a distinção entre o original e a cópia, o original e o plágio. Literature is not reduced to this form of archivizing and this form of law, but it could not outlive them and still be called literature. A partir dessa definição específica da literatura, Derrida indica que é ela - e tudo aquilo cuja existência depende de um arquivo cujo referente é ele mesmo, ou seja, tudo aquilo cujo referente não pode ser encontrado fora do arquivo - que mais se encontra em perigo diante de um desastre nuclear. Essa constatação é estarrecedora, talvez pouco convincente, e possivelmente irrisória diante do horror incalculável que poderia significar uma guerra nuclear total, mas para prosseguir na leitura do texto é preciso diferenciar entre aquilo que se encontra sob maior perigo e aquilo cuja importância é de maior valor. Se, seguindo o seu raciocínio, a guerra nuclear total significa o fim do arquivo - a destruição sem restos das instituições de memória coletiva -, então o que se encontraria mais vulnerável na era nuclear é a instituição da literatura, e tudo aquilo que, como a literatura, pelo menos desde o século XVIII, depende exclusivamente do arquivo. Aqui é necessário lembrar que o arquivo torna possível não apenas uma memória positiva, mas também um esquecimento sistemático - é inclusive 
nos registros do arquivo onde estão as possibilidades para desvios, erros e descobertas, formas clandestinas de influência que surgem desde a organização intertextual do arquivo. Now what allows us perhaps to think the uniqueness of nuclear war, its beingfor-the-first-time-and-perhaps-for-the-last-time, its absolute inventiveness, what it prompts us to think even if it remains a decoy, a belief, a phantasmatic projection, is obviously the possibility of an irreversible destruction, leaving no traces, of the juridicoliterary archive - that is, total destruction of the basis of literature and criticism. Not necessarily the destruction of humanity, of the human habitat, nor even of other discourses (arts or sciences), nor even indeed of poetry or the epic; these latter might reconstitute their living process and their archive, at least to the extent that the structure of that archive (that of a non-literary memory) implies, structurally, reference to a real referent external to the archive itself. I am taking care to say: to that extent, and on that hypothesis.

Mesmo com matizações e modulações, a proposição não parece menos incômoda e, de fato, o texto parece se tornar cada vez mais críptico, tanto mais quanto Derrida expande a sua noção de literatura: não é certo, ele diz, que todos os outros arquivos, indepentente de suas bases materiais, contem com um referente que exista em absoluta exterioridade relativa a eles, que exista fora de sua própria possibilidade. Se houver tal referente, ele continua, o arquivo pode reconstituir-se e, de alguma outra maneira, sobreviver. Mas se não houver este referente, ou na medida em que não houver este referente externo, os arquivos encontram-se na mesma situação da literatura. É possível dizer que esses arquivos participam da literatura no sentido de que a literatura produz o seu referente como um referente fictício ou fabuloso, ato que é em si dependente da possibilidade da constituição de um arquivo. That would lead to a 
considerable extension - some would say an abusive one - of the field of literature. But who has proven that literature is a field with indivisible and simply assignable limits? The events known by the name of literature are definable; and there is in principle a possible history of this name and of the conventions attached to the naming. But the same cannot be said of the structural possibilities of what goes by the name literature, which is not limited to the events already known under this name.

A partir desse momento, então, em que a definição de literatura passa a ser mais abrangente - talvez até abusiva, diz Derrida - dada a incerteza da existência daquilo que poderia ser chamado de um referente real e externo ao arquivo, para qualquer arquivo, as consequências da guerra nuclear passam a tornar-se proporcionalmente maiores, assim como o texto de Derrida parece adquirir mais volume, mais gravidade. Claro, pois se tudo é literatura, ou se quase tudo é literatura, é exatamente tudo, ou quase tudo, que se encontra em jogo diante da destruição iminente. Apesar disso, permanece a pergunta inevitável: por que ainda chamar de literatura tudo isso que pode vir a desaparecer? e o que isso tem a ver com o desejo, com o desejo, principalmente aqui, de Derrida?

Como é comum no pensamento de Derrida, o interesse está no questionamento do próprio funcionamento da linguagem. Neste texto não é muito diferente: a hipótese principal é de que o temor à guerra nuclear escancara no seu revés a fábula constitutiva dos dispositivos da vida humana e, ao fazê-lo, assemelha-se a certo modo de leitura, isto é, ao modo de leitura da desconstrução. The hypothesis of this total destruction watches over deconstruction, it guides its footsteps; it becomes possible to recognize, in the light, so to speak, of that hypothesis, of that fantasy, or phantasm, the characteristic structures and historicity of the discourses, strategies, texts, or institutions to be 
deconstructed. O que está sendo colocado em marcha hoje em nome da desconstrução, diz Derrida, pertence à era nuclear e à era da literatura. Desejar, ainda que hipoteticamente, a destruição total parece ser a própria condição da desconstrução e da literatura na medida em que a guerra nuclear como referente último e final expõe a precariedade da vida constituída. Mas, por outro lado, se o referente final é justamente a destruição total, sem restos, é preciso adiá-lo e é, segundo Derrida, justamente essa relação entre perseguição do referente, ao mesmo tempo em que se busca desviar dele, que caracteriza a literatura. We may henceforth assert that the historicity of literature is contemporaneous through and through, or rather structurally indissociable, from something like a nuclear epoch (by nuclear "epoch", I also mean the épochè suspending judgment before the absolute decision). The nuclear age is not an epoch, it is the absolute épochè; it is not absolute knowledge and the end of history, it is the épochè of absolute knowledge. Literature belongs to this nuclear epoch, that of the crisis and of nuclear criticism, at least if we mean by this the historical and ahistorical horizon of an absolute self-destructibility without apocalypse, without revelation of its own truth, without absolute knowledge. Derrida parece afirmar, portanto, que se não há ao final do fim uma revelação, se é isso que o fantasma da guerra nuclear pode nos dar para pensar, é preciso trabalhar contra o fim. Afinal, Fukuyama e Fukushima apontam para versões muito diferentes das características e consequências do fim da história: de um lado a ideia de que a democracia liberal realizou-se plenamente como o ideal da história humana, de outro um desastre nuclear ativado por um tsunami. Em After Fukushima: The Equivalence of Catastrophes, Jean-Luc Nancy discute uma teoria de "equivalente geral” para as catástrofes contemporâneas. O equivalente geral foi, para Marx, um regime inaugurado pelo dinheiro; Nancy expande essa noção com o intuito de explicar 
os emaranhados das relações simbióticas entre tecnologia e movimentos tectônicos, por exemplo, afirmando que o que existe de natural em um desatre natural é que ele naturalmente implica movimentos técnicos, sociais, econômicos e políticos ${ }^{24}$. Neste sentido, uma leitura possível do livro de Francis Fukuyama, The End of History and the Last Man, à revelia da estabilidade prevista no seu conceito de fim da história, uma espécie de stasis final e duradoura, é constatar já ali a ideia de que o triunfo do desejo liberal contém em si o poder de destruição inlocalizável. A equivalência significa um estado de forças que se governam a si mesmas, ou seja, uma situação em que a questão não passa mais pela decisão ou pelo cálculo humano, não importa quão avançados sejam os cálculos preventivos da engenharia ou os modelos premonitórios da meteorologia.

A épochè é o estado de suspensão da revelação, morrer com um segredo na boca, aquilo cujas condições de existência não podem ser reveladas fora de suas próprias condições e que, apesar disso, parecem caminhar rumo à eliminação de suas condições. Para Derrida, essa é a condição incondicional da literatura. The only "subject" of all possible literature, of all possible criticism, its only ultimate and a-symbolic referent, unsymbolizable, even unsignifiable; this is, if not the nuclear age, if not the nuclear catastrophe, at least that toward which nuclear discourse and the nuclear symbolic are still beckoning: the remainderless and a-symbolic destruction of literature.

\footnotetext{
${ }^{24}$ Jean-Luc Nancy está falando aqui das questões prementes do século XXI. Peter Sloterdjik, em seu livro Terror from the Air, focaliza o século XX para discutir como nele se inaugurou uma forma de terrorismo em que a estratégia de ataque consiste em retirar dos oponentes - por meio de formas técnicas, biológicas e químicas avançadas - aquilo sem as quais elas não podem sobreviver, as condições para os sistemas fisiológicos. A cena inicial dessa forma militar é, segundo ele, 22 de abril de 1915, data em que as tropas alemãs utilizaram gás de cloro contra soldados franco-canadenses, produzindo uma nuvem com seis quilômetros de extensão, sob a qual não era possível respirar. É neste momento, diz Sloterdjik, que o meioambiente como um todo (e não apenas a topografia ou a hidrografia) é introduzido como elemento decisivo na batalha: o que se ataca é não mais o corpo do adversário, mas o seu ambiente. A climatologia, isto é, o estudo do deslocamento das massas de ar surge, nesse momento, com fins táticos.
} 
Literature and literary criticism cannot speak of anything else, they can have no other ultimate referent, they can only multiply their strategic maneuvers in order to assimilate that unassimilable wholly other. They are nothing but those maneuvers and that diplomatic strategy, with the "doubletalk" that can never be reduced to them. De fato, protelar parece ser imperativo diante do risco de uma guerra nuclear, fato que se torna relevante hoje, novamente, com os ataques verbais cada vez mais agressivos trocados entre Donald Trump e Kim Jong-un, duas figuras para as quais a parcimônia definitivamente não é uma característica. A literatura, similarmente, não pode falar de outra coisa que não o seu refente inominável ao mesmo tempo em que não pode evitar falar de outas coisas. A suspensão parece ser a própria garantia da sobrevivência, a retórica diplomática sendo empregada para desenvolver uma guerra de dissuasão, um desmonte discursivo do arsenal de guerras, ainda que o número real de bombas só aumente. É essa suspensão, diz Derrida, que permite contrapor-se à velocidade e adiar a cena final, e que, precisamente, caracteriza a literatura - não sua instituição, mas a sua invenção -; sem poderes de cancelar o fim, convive com ele, opera paralisias temporárias.

Acompanhar o percurso de Derrida em defesa de uma crítica nuclear só é possível se a compreendermos como fruto do seu desejo em manter suspensa qualquer referencialidade externa à literatura, o que implica na escolha - surpreendente, depois de dedicar alguns parágrafos à expansão abusiva da noção de literatura -, de formas literárias bastante especificas: and in truth I believe that the nuclear epoch is dealt with more "seriously" in texts by Mallarmé, of Kafka, or Joyce, for example, than in presentday novels that would offer direct and realistic descriptions of a "real" nuclear catastrophe. Essa seria a literatura, segundo ele, que verdadeiramente faria a pergunta: 
o que é um referente? De onde pode se entender que essa é a literatura que correria mais risco diante de um desastre nuclear. Como veremos a seguir, nisso Derrida tem razão. Em seu texto, ele diz que an absolute míssil does not abolish chance. A pergunta, então, talvez seja outra e passa, certamente, pela questão da referencialidade: que literatura é possível depois de um desastre nuclear?

\section{$/ / /$}

Dois anos depois de Derrida apresentar o seu texto sobre um fim nãoapocalíptico, um reator explode em Chernobyl. A explosão não é o resultado de um conflito entre nações soberanas, mas mais bem o resultado do desgaste interno à sustentação de um projeto monumental como a União Soviética, que a essa altura já se encontrava às voltas com seus últimos suspiros. Com a força equivalente a 350 bombas de Hiroshima, o desastre de Chernobyl não resultou em uma destruição absoluta, sem restos, e deu origem, ao contrário de tudo que seria possível esperar, entre os escombros do terror, a uma outra forma de vida: de certa forma, a explosão do reator foi um acidente que produziu mais sobreviventes do que vítimas. No início dos anos 90 , Svetlana Aleksiévitch coletou as histórias orais de dezenas de sobreviventes, por meio das quais escreve um livro, o Vozes de Tchernóbil. Seu trabalho de escrita consiste na edição desses depoimentos, intitulados ora de monólogo (como, por exemplo, "Monólogo sobre a paisagem lunar"), ora de coro (como, por exemplo, "Coro de crianças"), a depender da organização das vozes das transcrições - a voz de Aleksiévitch, marcada como tal, isto é, não aquela que se constrói através da palavra alheia, aparece apenas no princípio e no final do livro. Ela o termina escrevendo que essas pessoas já 
haviam visto o que para todo mundo é ainda desconhecido. Me sentido como se estivesse gravando o futuro. ${ }^{25}$

Umas das questões para as vozes desses sobreviventes é determinar se, apesar de ser um desastre de outra ordem, um acidente decorrente do átomo pacífico, o que aconteceu em Chernobyl foi ou não foi uma guerra. Um dos soldados enviados para auxiliar na contenção da situação diz de início houve uma perplexidade geral. A sensação de que se tratava de manobras militares. De um jogo. Mas era uma guerra de verdade. Uma guerra atômica... Afinal, ali vivia-se em situação militar: postos de polícia, gente de uniforme militar, sistema de salvo-conduto, racionamento, funcionários que distribuem ajuda humanitária. Mas outros sobreviventes, principalmente aqueles que resistem à evacuação, duvidam da guerra - no céu havia estrelas, havia flores nas macieiras, ninguém os atacava, não havia ninguém atirando. Um homem, relembrando a segunda guerra mundial, memória comum a muitos dos entrevistados, afirma que não se pode comparar isso com uma guerra, não é exato, mas todos comparam. Quando eu era criança, sobrevivi ao bloqueio de Leningrado. É impossível comparar. Lá, nós vivíamos como no front, sob fogo cerrado. E sob a fome, anos de fome, quando o homem cede aos seus instintos mais baixos. E descobre a fera dentro de si. Mas aqui, ao contrário, tudo continua a crescer. Nada mudou no campo ou no bosque. É incomparável. Mas eu queria falar de outra coisa... Perdi o fio... Escapou... Ah, sim. Quando começa um bombardeio, é um Deus nos acuda! Você pode morrer não um dia, mas agora, nesse minuto. De fato, trata-se de uma guerra de outra ordem, uma guerra desde sempre perdida para o tempo

\footnotetext{
${ }^{25}$ Este trecho não consta na edição da Companhia das Letras, em que o epílogo da edição orginal russa (1997) e da tradução americana foi substituído pelo discurso de Aleksiévitch na premiação do Nobel em 2015.
} 
e para a contaminação. Nós nos preparávamos para uma guerra, para uma guerra atômica, construíamos abrigos atômicos. Queríamos nos proteger do átomo como nos defendíamos do estilhaço de um projétil. Mas o átomo está por toda parte... No pão, no sal... Respiramos radiação, comemos radiação.... Essa guerra tinha, portanto, um caráter peculiar, o inimigo se apresentava diante de nós com outro aspecto: sua marca mais notável era invisibilidade e a ubiquidade. E, no lugar de uma guerra internacional atômica, era preciso combater o próprio corpo, expelir radionuclídeos do próprio organismo.

É que a guerra parece ser travada contra a própria Terra, contra a própria vida, pois tudo nela torna-se vetor de radiação. Um soldado diz: Pelo caminho, vimos alguns cachorros e gatos que pareciam selvagens. Às vezes eles se comportavam de forma estranha, não reconheciam as pessoas, fugiam de nós. Eu não compreendia o que se passava com eles até que nos mandaram liquidá-los... Outro relata que as ordens eram absurdas e consistiam em remover os primeiros trinta centímetros de todos o solo: o que se enterrava era o próprio mundo, retirávamos a camada superior da terra, carregávamos os caminhões e transportávamos aquela terra para fossas comuns. A fossa, que eu imaginava ser uma complexa instalação técnica, era na verdade um grande buraco que se convertia em túmulo. A terra, nós levantávamos e enrolávamos em grandes rolos. Como um tapete. Uma capa verde com ervas, flores e raízes, aranhas e minhocas. Um trabalho de louco. Porque é impossível depurar a terra, separar dela o que é vivo. Se não bebêssemos toda noite, duvido que fosse possível aguentar. Os milhares de soldados convocados a Chernobyl e forçados a se exporem à radiação sem a menor das medidas de segurança também parecem entender o tamanho de seus crimes diante da fragilização daquilo que é a delimitação de um povo: Não sei em qual 
poeta li que os animais são outros povos. E eu os exterminava às dezenas, centenas, milhares, sem saber sequer como se chamavam. Destruía as suas casas, os seus esconderijos. Enterrava, enterrava... Os animais e os seus segredos, os animais e os seus arquivos. Cheguei ali quando os pássaros estavam no ninho e fui embora com as maçãs caídas sobre a neve. Não conseguíamos enterrar tudo. Enterrávamos a terra na terra. Com besouros, aranhas, larvas. Com todos esses diferentes povos. Com todo esse mundo. Eles foram a minha impressão mais forte. Foram eles, certamente.

Aquele mundo - a Zona - uma área de evacuação de 2600 quilômetros quadrados, depois da retirada das tropas, do enterro da terra, da chacina de animais, a despeito de tudo, ressurgiu. Muitas mulheres mais idosas retornaram, assim como chegaram outros fugindo de outros conflitos, na Chechênia, na Geórgia. A população de animais cresce, as árvores florescem. Parece surgir um novo povo, separado dos demais, que já não é exclusivamente humano. O mundo se dividiu: há os de Tchernóbil, nós; e há vocês, o resto dos homens. Você notou? Nós já não distinguimos: eu sou bielorrusso, eu sou ucraniano, eu sou russo... Todos nos chamamos pessoas de Tchernóbil. Nós somos de Tchernóbil, eu sou de Tchernóbil. É como se fôssemos um povo à parte... Uma nova nação.... Quem retornou à zona e quem chegou fugindo de algum lugar pior parece constituir outra relação com a natureza, porque já não é terra de ninguém. Deus a tomou. A população de animais parece ultrapassar a de humanos, que ocupam os seus espaços institucionais: quando passávamos por uma rua, um javali selvagem disparou da porta de uma escola e cortou o nosso caminho. Ou talvez fosse uma raposa. Os bichos viviam nas casas, nas escolas, nos clubes. E por ali, as placas diziam: "O nosso objetivo é a felicidade de toda a humanidade". Uma senhora que alimenta todos os animais que ficaram para trás conversa com o cachorro abandonado de seus vizinhos, Jutchók. 
"Jutchók", eu dizia a ele, "se você encontrar alguém, venha me chamar." Um cinegrafista quer ver tudo pelos olhos dos animais. Comigo aconteceu uma coisa incomum. Eu passei a olhar os animais com outros olhos. E também as árvores. Os pássaros. Observo o mundo ao redor com outros olhos. Uma pequena formiga se arrasta pela terra, e ela agora me é próxima. Um pássaro voa no céu e também me é próximo. Entre mim e eles, o espaço se reduziu. Não há mais o abismo de antes. Tudo é vida.

Muitos sobreviventes relatam a beleza assustadora, tanto do fogo quanto da terra que veio depois, e assim constituem o quadro de uma espécie de sublime nuclear, e desde essa perspectiva parecem atingir aquilo que parece impossível, que é sobreviver ao fim do mundo e poder olhar o que restou. Lembro aqui da música do R.E.M, it's the end of the world as we know it, and i feel fine (It's time I had some time alone). Um homem que viu as chamas do reator da varanda da sua casa com a sua família, descreveu-a assim: uma luz incrível. Não era um incêndio comum, era uma luz fosforescente. Era lindo. Se esquecermos todo o resto, era muito bonito. Eu nunca tinha visto nada igual nem no cinema, nada que pudesse ser comparado àquilo... Ele conta que as pessoas vinham de longe para acompanhar o incêndio. Outro sobrevivente diz que a pior parte era a beleza, essa mesma beleza era o que fazia daquele horror ainda mais pavoroso. Um homem foi viver na Zona para buscar a sua redenção, aqui me sinto à vontade. Posso dizer que aqui é o paraíso. Não há gente, só alguns bichos. Vivo entre bichos e pássaros. Por acaso estou sozinho? Em dezenas de quilômetros, não se vê uma só pessoa. Os demônios são expulsos com jejum e oração. O jejum é para a carne, a oração, para a alma. Agora um homem livre. A radiação parece tomar proporções transcendentais e a sua invisibilidade, a sua presença spectral, pode conceder a ela uma aparente arreferencialidade: a culpa é da radiação ou de quem? Como ela é? Vai ver, 
mostraram-na em algum filme. Você viu? Ela é branca ou o quê? De que cor? Uns contam que ela não tem cor nem cheiro, outros contam que é negra. Como a terra! Se não tem cor, é como Deus: está em todo lugar, mas ninguém vê. Querem nos assustar. As maçãs estão penduradas nas árvores e as folhas também, as batatas estão crescendo no campo...

Mas se só existe uma Terra - esta -, como nos lembra uma senhora retornada, e se da descrição de beleza passa-se a uma descrição do sublime, ou seja, se daquilo que se submete a nós passa-se necessariamente a um inimigo invisível ao qual é preciso submeter-se, a perspectiva de uma Zona que triunfa uma vez liberta da espécie humana parece ganhar outros matizes: e de repente me dou conta de que não sinto nenhum cheiro. O jardim floresce, mas não há aroma. "Que tal o aroma da maçã?" "Não tem aroma nenhum." Estava acontecendo conosco... Os lilases não tinham perfume. Os lilases! De início tive a sensação de que tudo o que me rodeava não era de verdade. Como se eu estivesse no meio de um cenário. Uma mulher, Larisa Z., cuja filha nasceu com muitos efeitos adversos da radiação, conta de uma passagem na bíblia, que por sua vez Ihe foi contada por sua avó: de que sou culpada? No início, queriam evacuar o nosso povoado, mas depois apagaram-no da lista: o Estado não tinha dinheiro. Foi na época em que me apaixonei e me casei. Eu não sabia que para nós, aqui, era proibido amar. Muitos anos atrás, a minha avó leu na Bíblia que chegaria o tempo em que na Terra haveria de tudo em abundância, tudo floresceria e frutificaria, os rios se encheriam de peixes, e os bosques de animais; mas que o homem não poderia tirar proveito disso, $e$ tampouco dar à luz os seus semelhantes e prolongar a sua imortalidade. Eu escutava aquelas velhas profecias como um conto de terror. 
Talvez aqui seja um bom momento para retornar a Derrida e ao fim do mundo como fim do arquivo. O depoimento acima é só um dos muitos que recorrem aos livros para estabelecer um ponto de comparação com a nova realidade. Nele parece estar sintetizado o fim do referente arquivístico na medida em que o desastre nuclear de Chernobyl o transforma em um referente externo, isto é, a fábula torna-se real, a profecia se cumpre, atualizando aquilo que até aquele momento só existia no âmbito das virtualidades. Não é tanto, portanto, o fim do arquivo como motor interno à literatura - o andarilho da Zona conta que aqui é simples encontrar livros, é fácil encontrá-los. Uma jarra de barro vazia você não encontra, nem garfos ou facas, mas os livros estão por aí-, mas mais bem a indistinção entre aquilo que seria interno e aquilo que seria externo ao arquivo. O castigo dessa realização é não poder gozar dessa atualização, pois há indistinção entre o que é real e o que é artifício; há árvores em flor, mas não é possível cheirá-las. Em The Politics of Literature, de J. Rancière, ele faz uma pergunta: por que Flaubert matou Emma Bovary? Sua sugestão é de que ela deve ser morta por confundir literatura e vida. Claro, ele segue dizendo, porque isso significa o próprio fim da especificidade da literatura. There has to be a good and a bad way of dealing with this indistinction. And it is the bad way that the author has to embody in his character. He has to construct the character as his opposite, as the anti-artist. The good way, the artistic way of dealing with the indistinction, consists in sticking it exclusively in the book, in the book as a book. The bad way, the character's way, consists in sticking it in real life. Mas talvez não seja mais possível simplesmente "enfiar" a indistinção em um livro; qualquer que tenha sido a lógica que possibilitava passar da vida ao livro, ela já não parece mais possível - um homem conta que tentou escrever uma história: durante muito tempo essa visão me perseguiu, tentei escrever um conto. Imaginei o que se 
passaria aqui, como seria daqui a cem anos: algo parecido a um homem, ou a alguma coisa que saltava com quatro patas, lançando as suas longas pernas traseiras para o ar; uma criatura que à noite enxergaria tudo com o seu terceiro olho; que graças à sua única orelha cravada no alto da cabeça seria capaz de ouvir a corrida de uma formiga. Apenas as formigas haviam restado, todo o resto, na terra e no céu, havia perecido. Mandei o conto para uma revista. Responderam que aquilo não era literatura, mas um relato de terror. É que Chernobyl tornou-se mais fantástica que a literatura na sua própria realidade, fato pelo qual muitos sobreviventes de Chernobyl são, em geral, anti-artistas: um soldado, olhando os túmulos, enxerga poemas: longas colunas com o nome dos soldados rasos, como versos...; uma avó, lembrando dos netos, se imagina em uma ilha: "vovó", perguntam, "você leu o livro do Robinson [Crusoé]?" Ele também vivia só, como nós. Ou um outro que diz: somos metafísicos. Não vivemos na terra, mas nas nossas quimeras, nas nossas conversas. Nas palavras. É que os primeiros a morrer parecem ser os robôs; tanto em Chernobyl, quanto em Fukushima, com outra tecnologia mais avançada, os robôs sucumbem quase imediatamente à radiação - a tecnologia resultante daquilo que Derrida denominou como o arquivo com referente externo a ele mesmo não parece ter qualquer utilidade nessa situação. Não há nada que a física e a química e a matemática possam fazer por nós.

O que as pessoas fazem, então? Escrevem. Aprendem de cor. Oferecem outra teoria para a referencialidade da literatura, expõem a dimensão externa do seu vasto arquivo. As pessoas escreviam o nome nas casas. Nas vigas, nas cercas. No asfalto. A escrita torna-se o rastro possível contra o rastro da radiação: já contei isso, ou não? Eu me aproximei e pensei que a casa estava vazia. Abri a porta e havia um gato sentado lá dentro... E também essas cartinhas das crianças... Pedem e inscrevem suas desculpas às 
paredes - Perdoe-nos, casa querida! Um homem rouba a sua própria porta, lá estão as marcas de crescimento de toda a sua família, proibiram-nos de levar os objetos! Eu não levei as minhas coisas. Apenas uma: tinha que retirar a porta do apartamento e levá-la comigo, não podia deixá-la. Fechei a entrada com tapumes. A nossa porta é o nosso talismã! É relíquia familiar. Sobre essa porta velamos o meu pai. Não sei que costume é esse, nem todo lugar é assim, mas entre nós, como disse a minha mãe, devemos pôr o defunto sobre a porta de casa. Velamos a pessoa ali até chegar o caixão. Passei a noite inteira junto do meu pai, que jazia sobre essa porta... A casa ficou aberta... A noite toda... E nessa mesma porta, até o alto, estão as marcas... Conforme eu ia crescendo, anotávamos: primeiro ano. Segundo. Sétimo. Antes do Exército. E ao lado estão as do meu filho. Da minha filha. Nessa porta está escrita toda a nossa vida, como nos papiros antigos. Como eu poderia deixá-la? Larisa Z., mãe da menina que nasceu e vive desde então em um hospital por causa dos efeitos da radiação, pede a Aleksiévitch, conte $a$ todo o mundo sobre a minha filha. Escreva. Aos quatro anos ela canta, dança, recita poesias de cor. Ela tem um coração e por isso decora ou ela sabe decorar e por isso tem um coração, ela diz, como se a indicar que ela dá continuidade ao arquivo e por isso também mereça fazer parte dele. Decorar, escreve Derrida em outro texto, um texto talvez mais alinhado, involuntariamente, a uma ideia nuclear da literatura, "Che cos'è la poesia?", é o gesto impossível diante da catástrofe que constitue a poesia: Eat, drink, swallow my letter, carry it, transport it in you, like the law of a writing become your body: writing in (it)self. The ruse of the injunction may first of all let itself be inspired by the simple possibility of death, by the risk that a vehicle poses to every finite being. You hear the catastrophe coming. From that moment on imprinted directly on the trait, come from the heart, the mortal's desire awakens in you the movement (which is contradictory, you 
follow me, a double restraint, an aporetic constraint) to guard from oblivion this thing which in the same stroke exposes itself to death and protects itself-in a word, the address, the retreat of the hérisson, like an animal on the autoroute rolled up in a ball. One would like to take it in one's hands, undertake to learn it and understand it, to keep it for oneself, near oneself.

Enquanto houver sobreviventes ainda haverá algum tipo de arquivo, parece óbvio dizer, inclusive porque o próprio modo de determinação de um fim só é possível em função de um arquivo, eu lembro que nos primeiros dias depois do acidente, os livros sobre radiação desapareceram da biblioteca, e os livros sobre Hiroshima e Nagasaki, e até os que tratavam de raios $X$. Corria o boato de que era ordem do chefe para evitar pânico, que isso era para a nossa segurança. Surgiu até a piada de que se Tchernóbil tivesse ido pelos ares em terras papuas, todo mundo teria se assustado, menos os papuas. Não havia nenhuma recomendação médica, nenhuma informação. É claro que aqui a piada não faz o mais difícil, que é tentar imaginar como seria a leitura de um desastre nuclear em um lugar que desconhecesse as unidades roentgen, microrroentgen... era linguagem de outro planeta. A radiação seria percebida de uma forma ou outra, a sua letalidade apesar de sua invisibilidade é evidente. Morrer também é diferente depois de um desastre nuclear: aqui, agora, tudo é diferente: nascemos e morremos de outro modo. Não mais como os outros. Você me perguntará como morrem depois de Tchernóbil, mas de que maneira a morte radioativa seria explicada, por exemplo, em terras papuas, com recurso a qual arquivo? - e nesse arquivo haveria a ideia de um referente, teriam estes outros arquivos também já previsto uma versão de fim? Uma mulher conta que recebeu a visita de um amigo, ele diz a ela: "Vocês são como 'caixas-pretas'. São pessoas 'caixas-pretas'. Há 'caixas-pretas' em todos os aviões, elas 
registram todas as informações do voo. Quando o avião sofre uma avaria, encontram as 'caixas-pretas'". Nós pensamos que vivemos como todo mundo. Andamos, trabalhamos, amamos... Não! Nós registramos informações para o futuro. Se, seguindo os abusos de Derrida, expandirmos ainda mais a ideia da literatura, levá-la até onde Derrida não chegou, parece ser inevitável chegar ao corpo como repositório máximo do arquivo, aquilo para o qual a conjugação terá havido não cabe, pois é o corpo quem media o fluxo entre passado e futuro, é nele que se inscreve a radiação, o que significa que os mortos devem passar a ser enterrados em caixões de chumbo. Não é a própria radiação natural da matéria orgânica que permite asseverar a idade das coisas, uma narração espectral? Não seria esse rastro também o da literatura? 
/3. ez $\ln ^{26} \backslash$

Sin nombre se nombra, cara sin rostro, todos y ninguno, unos y muchos, vivo muerto.

- Subcomandante Insurgente Marcos (1994)

Entenderán que es como um drone subterrâneo y tendrán el privilegio de una mirada desde las profundidades de la resistencia zapatista.

- SupGaleano (2015)

No dia 26 de Maio de 2014, vinte anos depois de sua primeira aparição, o Subcomandante Insurgente Marcos veio a público para anunciar que, a partir daquela

\footnotetext{
${ }^{26}$ Este texto surgiu em função da curiosidade acerca de uma espécie de poética (neo)zapatista, isto é, de uma pergunta sobre uma forma estratégica e deliberada de apresentação que parece minar, justamente, as possibilidades de representação. Isto, é claro, não deve sugerir que o EZLN, em seu funcionamento interno, não se utilize da lógica de representatividade para constituir, por exemplo, suas Juntas de Buen Gobierno ou a hierarquia de comando. É importante frisar que o EZLN é, principalmente, a organização política em torno da autonomia comunitária, territorial e cultural de uma parcela significativa da população indígena do estado de Chiapas. Com relação a isso, especificamente, este texto tem pouco a dizer. A operacionalização propriamente dita do EZLN é, com toda razão, em grande parte, desconhecida. Há pouco material com relação ao número de comunidades que são realmente zapatistas, poucos dados com relação às suas dinâmicas políticas internas, poucos estudos sobre a natureza e a escala das transformações nas comunidades indígenas pós-EZLN. No entanto, o EZLN produz, desde 1994, quando se deu a conhecer ao mundo - embora as mobilizações tenham começado, pelo menos, vinte anos antes uma quantidade vertiginosa de declarações, pronunciamentos, comunicados, cartas e outras emissões de ordem discursiva, por meio das quais negociam com as formas modernas, capitalistas e ocidentais de circulação dos significados. No final de 2016, tive a oportunidade de participar de algumas atividades do EZLN em Chiapas, ao longo de dez dias. Se nelas confirmei minha hipótese com relação à função do Subcomandante Marcos/Galeano (e que naqueles dias falava sob o nome de SupAlquimista Galeano), também pude notar que ao meu texto faltavam considerações importantes sobre as transformações internas ao EZLN nos últimos 23 anos e as demandas colocadas pelas novas gerações de zapatistas, transformações que eu diluía ao utilizar as declarações de maneira descontextualizada, sendo que essas declarações dão - justamente - conta dessas transformações (a insurgência, as negociações de paz, a articulação do Congreso Nacional Indígena [CNI], a forte ofensiva paramilitar, o desarmamento em nome de uma política de vida e agora, recentemente, o apoio à candidatura da porta-voz do CNI à presidência). $\mathrm{E}$, principalmente, ao desconsiderar essas transformações, ou mencioná-las apenas brevemente, não pude dar devida importância àquilo que se chamou de "o silêncio" zapatista e sua conexão direta com aquilo que é, em grande medida, reflexo de um modo de compreensão de uma questão-chave para a esquerda e em função da qual já se produziu muito material: a derrota. Mas a tentativa de reescrita desse texto, assim como esta nota, começou a tomar proporções desmedidas, de modo que decidi deixar o texto como estava, apenas com algumas pequenas modificações.
} 
data, deixaria de existir. Não se tratava - parece estar bastante claro - de uma renúncia, já que a renúncia pressupõe uma pessoa separada da função a qual renuncia.

Pensamos que es necesario que uno de nosotros muera para que Galeano ${ }^{27}$ viva.

$Y$ para que esa impertinente que es la muerte quede satisfecha, en su lugar de Galeano ponemos otro nombre para que Galeano viva y la muerte se lleve no una vida, sino un nombre solamente, unas letras vaciadas de todo sentido, sin historia propia, sin vida.

Así que hemos decidido que Marcos deje de existir hoy. $[\ldots]$

Por mi voz ya no hablará la voz del Ejército Zapatista de Liberación Nacional. (2014).

O que se realiza é uma troca, onde o EZLN cede um nome por outro. Simultaneamente ao desparecimento de Marcos, uma voz surge, em off, Buenas madrugadas tengan compañeras y compañeros. Mi nombre es Galeano, Subcomandante Insurgente Galeano. Diferente da renúncia, portanto, o que essa operação evidencia é que Marcos nunca havia de fato existido como pessoa - apenas, portanto, um nome ${ }^{28}$, essa linguagem que existe fora da linguagem -, deixando intacta,

\footnotetext{
${ }^{27}$ Galeano, professor zapatista, foi morto pelos paramilitares em 2 de maio de 2014.

${ }^{28}$ Tanto Marcos quanto Galeano já eram participantes do jogo dos nomes, tomando-o de outros. Marcos afirma tê-lo tomado de um colega que morreu, Galeano o tomou do escritor uruguaio Eduardo Galeano. O nome próprio passa a ser nome coletivo ou, como sugere Paul B. Preciado, há uma desprivatização do nome.
} 
ao dar seu adeus, a função. A ideia subjacente à brincadeira, embora tudo isso seja muito sério, é uma pessoa - uma figura - que só existe em função de, isto é, como função. Essa função é a própria voz, que não apenas se articula como uma política estética peculiar, desestabilizando os mecanismos de inclusão e representação, mas veicula também a negociação entre silêncio e fala, cisão sobre a qual se estabelecem as forças políticas.

\section{$/ / /$}

O pasamontanãs utilizado pelo EZLN cobre o rosto de seus integrantes. Como toda máscara, ela determina uma relação específica com o outro: a habilidade de ver sem ser visto. A política aqui não consiste em tornar-se visível ao outro, ou seja, não é pela face que a demanda ética é colocada ao outro. Ao mesmo tempo, para quem também utiliza a máscara, ela possibilita um modo de subjetivação que não representa um "eu" para si mesmo, ou seja, para um eu que antecede a máscara, mas sim para o acontecimento, para o zapatismo. Apesar da hierarquia militar, opera-se sob a lógica de mandar obedecendo, em que torna-se impossível imaginar, por exemplo, como seria seguir uma única pessoa quando todos estão com a mesma máscara: É você que está nos liderando? Não, pensei que fosse você quem estava nos liderando. Nessa configuração que devém matilha, Marcos aparenta ter destaque, no entanto, esse destaque é só isso mesmo, aparente, isto é, repousa apenas em sua figura elusiva, que distrai quem olha de fora. Marcos é também uma máscara.

Nuestros jefes y jefas dijeron entonces:

"Sólo lo ven lo pequeño que son, hagamos a alguien tan pequeño como ellos, que a él lo vean y por él nos vean" 
Empezó así una compleja maniobra de distracción, un truco de magia terrible y maravillosa, una maliciosa jugada del corazón indígena que somos, la sabiduría indígena desafiaba a la modernidad en uno de sus bastiones: los medios de comunicación.

Empezó entonces la construcción del personaje llamado "Marcos". (2014).

Contando com a sua própria invisibilidade - que já se dava diante do Estado mexicano, antes das máscaras -, e utilizando-a agora como arma, o EZLN escolhe o único integrante não-indígena para realizar um jogo de espelhos com quem opera sob a lógica narcísica dos poderes constituídos da modernidade. Atrás desse espelho, porém, não há nada, nada a ser capturado - Quienes amaron y odiaron al SupMarcos ahora saben que han odiado y amado a un holograma. Sus amores y odios han sido, pues, inútiles, estériles, vacíos, huecos -, pois o que Marcos esconde é precisamente a forma de enunciação ao qual ele presta a voz - um lugar deslocado, como veremos, em relação aos limites estabelecidos entre fala e não-fala - , assim como o que o pasamontañas esconde são não os olhos, mas justamente a boca dos zapatistas. O personagem do Subcomandante Marcos forjou-se como uma forma de alimentar e, simultaneamente, neutralizar os que detêm o poder sobre a produção e a circulação da linguagem, fenômeno que não se limita, evidentemente, aos poderes de comunicação:

creándole su arma homicida, hacerle creer que es efectiva, conminarlo a construir, en base a esa efectividad, todo su 
plan, para, en el momento en que se prepara para disparar, el "arma" vuelva a ser lo que siempre fue: una ilusión. (2014).

O que resta é a voz, que é tampouco a voz de Marcos, pois Marcos é apenas o dispositivo dessa voz, isto é, quem fala é Marcos, mas ele enuncia desde um lugar plural, inlocalizável. O nós que ele pronuncia não é esse nós que fala em nome de - afinal, o nome já se tornou mera moeda de troca com a morte -, mas através do qual se fala, um nós como disjunção inscrita na própria enunciação. Um nós, como sugere Nancy, em The Birth to Presence, happening as the togetherness of otherness.

Há nesse privilégio dado à voz, em detrimento da imagem, uma proposição ética que faz repensar a centralidade da face como emissor da demanda ética. Se, para Lévinas, é o rosto quem dá sentido à responsabilidade, sendo o rosto o que está exposto - em sua fragilidade - ao outro, aquilo que proíbe de matar, Derrida em "Il fault bien manger" sugere que é da boca que pode surgir uma ética que não pressupõe um sujeito previamente existente, a quem se endereçaria a responsabilidade. Em "Bucalidade", Sara Guyer lê o texto de Derrida de modo a compreender essa responsabilidade que antecederia o sujeito, se manifesta antes mesmo do sujeito, não apenas diante dele, reconfigurando, assim, um humanismo não antropocêntrico (longe de ser um oxímoro, penso aqui em Viveiros de Castro e sua investigação sobre a cosmologia ameríndia onde no princípio tudo era humano) em que os animais e os mortos também passariam a compor o circuito ético. Porque "Não matarás" é o que Lévinas denomina "primeira palavra" do rosto, e porque o mandamento jamais foi compreendido como uma proibição de "matar em geral", essa injunção - como demonstra Derrida - quer dizer 
apenas "Não matarás o teu próximo". Trata-se de um imperativo que "é dirigido ao outro e o pressupõe. Destina-se à própria coisa que institui, o outro como homem".

Ao propor um furo na face, um defacement, a ética não se regula mais pela divisão entre não matar o próximo e não matar em geral; o furo faz entrever uma alteridade radical que não depende apenas do reconhecimento do próximo, daquele que é igual - ou demasiadamente parecido - a si. Derrida escreve que se o limite entre o vivo e o não vivo agora parece tão incerto, ao menos como limite entre oposições, tal como aquele entre "homem" e "animal"; e se, na experiência (simbólica ou real) do "comer-falar-interiorizar", a fronteira ética não mais passa rigorosamente entre o "Não matarás" (o homem, teu próximo) e o "Não darás morte aos vivos em geral", mas entre vários e infinitamente diferentes modos de concepção-apropriação-assimilação do outro - então, no que concerne ao "Bem" de toda moralidade, a questão retorna à determinação daquela que seja a melhor, a mais respeitável, a mais recompensadora e também a mais generosa maneira de me relacionar com o outro e de relacioná-lo comigo. Para tudo que acontece à borda de orifícios (o da oralidade, mas também os do ouvido, do olho e de todos os "sentidos" em geral), a metonímia do "comer bem" [bien manger] seria sempre a regra.

Segundo Guyer, se os limites entre o animal e o humano, vivo e não vivo, se proliferam e se borram, há um curto-circuito também na oposição entre "não comer" e "não matar", "não comer homem ou animal", o que faz a ética ser questionada, reatualizada, sempre que uma palavra ou substância passa pela fronteira da boca. Se existe a possibilidade de comer enquanto se fala, falar de boca cheia ou falar de boca vazia, ou comer-falar-interiorizar ao mesmo tempo e sem distinção [...], a oposição 'falar ou matar' não mais se sustenta. O que resulta disso é uma ética que se desdobra diante 
da abertura - uma responsabilidade que se recusa a sancionar a violência, ao mesmo tempo em que reconhece a violência de sua própria demanda -, cuja lei é regulada pelo il faut bien manger, comer bem, comer o bom.

O que fura o rosto - orificializa o rosto - não é só a boca, mas também o ouvido, que forma a caixa acústica de onde e por onde a voz reverbera. Em Listening, Jean-Luc Nancy propõe que assim como os significados, o som é também feito de referências (refferals): ao se espalhar pelo espaço exterior, ele ressoa ao mesmo tempo em que ressoa dentro de quem o emitiu, that is, it re-emits itself while actually sounding, which is already "re-sounding" since that's nothing else but referring back to itself. To sound is to vibrate in itself or by itself: it is not only for the sonorous body, to emit a sound, but it is also to stretch out, to carry itself and be resolved into vibrations that both return it to itself and place it outside itself.

Essa caixa de ressonância, porém, não existe sozinha no espaço, mas compartilha o espaço com outras caixas, incontáveis outras caixas, que compõem uma rede sonora, e em diversos vetores e ondas, cortam o espaço, vão e voltam. A política da voz é também uma política da escuta. Comer o bom, nesse sentido, quer dizer também não dar ouvidos apenas ao próprio eco, mas constituir uma rede de sussurros que mantém a escuta livre para irrupções inesperadas e, assim, o EZLN defende um canal distinto de comunicação, onde o que se comunica não é necessariamente o sentido, mas o que existe em comum, o que pode fazer entrever a comunidade no que diz respeito não à comunalidade das pessoas, mas às pessoas da comunalidade. Também furam, assim, as redes já mapeadas das formas sancionadas do discurso. 
¿Qué le decimos a ese cadáver al que, en cualquier rincón del mundo de abajo, se le entierra en el olvido?

¿Que sólo nuestros dolor y rabia cuentan?

¿Que sólo nuestro coraje importa?

¿Que mientras susurramos nuestra historia, no escuchamos su grito, su alarido?

Tiene tantos nombres la injusticia y son tantos los gritos que provoca.

Pero nuestro dolor y nuestra rabia no nos impiden escuchar.

Y nuestros susurros no son sólo para lamentar la caída de nuestros muertos injustamente.

Son para así poder escuchar a otros dolores, hacer nuestras otras rabias y seguir así en el complicado, largo y tortuoso camino de hacer de todo eso un alarido que se transforme en lucha libertadora.

Y no olvidar que, mientras alguien susurra, alguien grita.

Y sólo el oído atento puede escuchar

Mientras hablamos y escuchamos ahora, alguien grita de dolor, de rabia.

Y así como hay que aprender a dirigir la mirada, la escucha debe encontrar el rumbo que la haga fértil. (2014). 
A diferença entre a vista e a escuta é que a primeira opera sob a lógica da evidência, capta somente aquilo que está lá, no presente, em espaço contíguo, enquanto a segunda percorre o espaço, atravessa a matéria, dispara uma emissão em cadeia. Se o visual, segundo diz Nancy, persiste até a sua desaparição, o sonoro aparece e arrefece into its permanence. Essa permanência, percebida e catalizada pelo EZLN, resulta e provém da disposição em falar com fantasmas e interiorizar, como parte indelével do presente, a demanda dos mortos, desses gritos em silêncio.

O fantasma, como o EZLN, nos vê sem que o vejamos e, assim, impossibilitados de identificar o fantasma, impossibilitados de ter certeza daquilo que vemos, só podemos confiar em sua voz, que faz ecoar a própria força do anacronismo, isto é, a demanda de quem já não é mais; a demanda de quem ainda está por vir. A voz, seja do sussurro, seja do alarido, sempre ambas uma espécie de cacofonia para quem está acostumado a afinar o ouvido em outros tons, existe antes de qualquer pergunta sobre inteligibilidade; a voz é frequência sonora - atinge vida e não-vida. E talvez os olhos, como sugere Derrida em Memoirs of the Blind, sirvam menos para ver e mais para chorar.

\section{$/ / /$}

A modernidade, à esquerda e à direita, isolou o fantasma, se dispondo somente a negociar com o que tem presença material. O corpo do morto confinado, sem sobrevida, um objeto inerte, à mercê da decomposição, rumo à desaparição; em seu lugar, uma lápide, um nome, no máximo uma estátua pétrea ou, hoje, com os avanços tecnológicos, um holograma, que impõem a vida sobre a morte. Quer-se vencer a morte, como se a dizer nós, os vivos, não temos nada que ver com a morte; nós, os vivos, não vemos a morte e assim manter ereta a parede que separa a vida da morte. No entanto, 
o fascínio com os zumbis sugere que não basta encerrar o morto nas gavetas do necrotério - os mortos retornam, a desaparição reaparece na própria desaparição da aparência; é preciso aprender a falar com os fantasmas: it is necessary to speak of the ghost, indeed to the ghost and with it, from the moment that no ethics, no politics, whether revolutionary or not, seems possible and thinkable and just that does not recognize in its principle the respect for those others who are no longer or for those others who are not yet there, presently living, whether they are already dead or not yet born.

Em Specters of Marx, Derrida se vale do genitivo para explorar tanto os próprios espectros de Marx que podemos herdar quanto os espectros que assombram Marx. Como os seus adversários, diz Derrida, Marx - contra a especulação - nunca cessou, na sua tentativa de exorcizar os fantasmas, de distinguir entre vida e morte, entre simulacro e presença real. Se exorcizar consiste em neutralizar a efetividade do fantasma, daquilo que está mais além da vida, o zapatismo se ancora sobre o gesto contrário. É a partir da morte de Galeano, da voz em off, que se quer dar sobrevida ao movimento. A morte é viva; os mortos-vivos também são zapatistas. O morto é não mais objeto estéril, mas sujeito político.

Vimos que ya no pudieron mantener callados a nuestros muertos, muertos hablaron los muertos nuestros, muertos acusaron, muertos gritaron, muertos se vivieron de nuevo. Ya no morirán jamás los muertos nuestros. Estos muertos nuestros siempre nuestros y siempre de los todos que se luchan. (1998). 
É a morte que anima a retransmissão da herança, que inscreve no presente o passado e o escancara para o futuro. A cosmologia zapatista tem como elemento central Votán Zapata - uma figura sincrética que mistura Votán, segundo os maias tzeltales o primeiro homem enviado para distribuir a terra entre os indígenas, e Emiliano Zapata - tímido fuego que en nuestra muerte vivió 501 años.

Desde la hora primera en esta larga noche en que morimos, dicen nuestros más lejanos abuelos, hubo quien recogió nuestro dolor y nuestro olvido. Hubo un hombre que, caminando su palabra desde lejos, a nuestra montaña llegó y habló con la lengua de los hombres y mujeres verdaderos. Era y no era de estas tierras su paso, en la boca de los muertos nuestros, en la voz de los sabedores ancianos, caminó su palabra de él hasta el corazón nuestro. Hubo y hay, hermanos, quien siendo y no siendo semilla de estos suelos a la montaña llegó, muriendo, para vivir de nuevo, hermanos, vivió muriendo el corazón de este paso proprio y ajeno cuando casa hizo en la montaña de nocturno techo. Fue y es su nombre en las nombradas cosas. Se detiene y camina en nuestro dolor su palabra tierna. Es y no es en estas tierras: Votán Zapata, guardián y corazón del pueblo. (1994). 
Votán Zapata é o próprio espectro, ao mesmo tempo ausência e presença, colocado sempre na indistinção entre ser e não ser, de onde emana a palavra dos mortos - as palavras caminhando de boca a boca entre os mortos; a morte como a própria garantia da palavra, em que se morre para viver. Derrida pergunta: What does it mean to follow a ghost? E ainda: And what if this came down to being followed by it, always, persecuted perhaps by the very chase we are leading? Conclui: Here again what seems to be out front, the future, comes back in advance: from the past, from the back.

$$
\begin{aligned}
& \text { I// } \\
& \text { Next, one cannot speak of } \\
& \text { generation of skulls or spirits [...] } \\
& \text { except on the condition of language } \\
& \text { - and the voice, in any case of that } \\
& \text { which marks the name or takes its } \\
& \text { place ("Hamlet: That Skull had a } \\
& \text { tongue in it, and could sing once") }
\end{aligned}
$$

A pergunta "Pode o subalterno falar?" causou impactos profundos nas áreas de estudos culturais, mas terminou por polarizar a questão - embora essa polarização não esteja dada no livro de Spivak - de modo a evocar dois tipos de respostas: "sim, os subalternos podem falar" e "sim, os subalternos podem falar, mas não sabemos escutálos". Abraham Acosta vem tentando desatar esse nó através do que ele chama de thresholds of illiteracy, por meio do qual ele busca as brechas de ilegibilidade e indistinção desde dentro da hegemonia semiótica. O problema central, para ele, está no fato de não se reconhecer que o subalterno não é a causa da pergunta "pode o 
subalterno falar?", mas o próprio efeito dessa pergunta, de modo a constituir um outro que é sempre tão somente a sombra de si mesmo: when the subaltern is posited as the cause and not the negative constitutive effect of the politico-intellectual relation, the line between 'can the subaltern speak?' and 'how can the subaltern [be made to] speak?' is indisinguishable. Partindo do pressuposto de Rancière - de que o que torna uma ação política não é objeto ou o lugar, mas sua forma - Acosta pergunta-se sobre como considerar a linguagem zapatista no contexto da subalteridade.

O consenso que ele visa desconstruir, porque já está desde sempre em desconstrução, parece ser de que os zapatistas, por meio de uma forma de tradução, podem, então, finalmente falar, colocando o mecanismo da tradução como aquilo que permite ao silêncio tornar-se fala. O enfoque dado à tradução ao mesmo tempo preserva e reduz a alteridade somente ao que é traduzível. Dentro desse circuito lógico, os zapatistas, portanto, manifestariam um silêncio barulhento, um silêncio que se converteria em barulho: o silêncio subalterno traduzido à fala. Esse barulho, então, é sancionado ao mundo do logos e do cogito, irrompendo no horizonte da democracia e transformando-a simultaneamente. A pergunta que fica, então, é: in other words, is Zapatista silence disruptive to hegemonic discourse because it is simply 'noisy' and silent simultaneously, or because, beyond noise, this silence is actually a form of speech?

Depois de emitida a Sexta Declaración da la Selva Lacandona em $2005^{29}$, o EZLN diminiu radicalmente a circulação de seus comunicados, principalmente aqueles por parte do Subcomandante Insurgente Marcos, além da restrição de entrada em seu

\footnotetext{
29 Declaração em que o EZLN realiza um balanço de sua trajetória, reconsidera os aspectos militares do EZLN e o redirecionamento de seus esforços ao fortalecimento de suas comunidades autônomas, e chama a sociedade civil mexicana a juntar-se a luta geral contra o neoliberalismo. Dessa chamada pública surge a La Otra Campaña, no início de 2006, um esforço de articulação nacional entre diversas organizações apartidárias.
} 
território de pesquisadores e brigadas estrangeiras, o que gerou uma série de especulações acerca dos sentidos deste silêncio. Ao longo do ano de 2011 não emitiram nenhum comunicado. No dia 21 de dezembro de 2012 - data do suposto fim do mundo, mas na verdade no calendário maia o encerramento de um ciclo equivalente a 394 anos - o EZLN realizou a Marcha del Silencio. Mais de 40 mil zapatistas marcharam em Chiapas, em absoluto silêncio. Na mesma data, emitiram um comunicado sobre a sua marcha silenciosa.

¿Escucharon?

Es el sonido de su mundo derrumbándose.

Es el del nuestro resurgiendo.

El día que fue día era noche.

Y noche será el día que será el día.

¡DEMOCRACIA!

iLIBERTAD!

iJUSTICIA!

Desde las montañas del Sureste Mexicano.

Por el Comité Clandestino Revolucionario Indígena -

Comandancia

General del EZLN.

Subcomandante Insurgente Marcos.

México, Diciembre de 2012. 
O problema está em não reconhecer a força do silêncio zapatista por aquilo que faz ou dispara, isto é, pela força de gatilho do próprio silêncio, mas apenas por o que está contido no silêncio, ou seja, naquilo que pode ser traduzido como o barulho da democracia. No anseio em des-subalterizar o discurso zapatista, ou seja, em legitimar o seu lugar no espaço de disputa hegemônico, o silêncio permanece como o lugar da nãofala, o que equivale a dizer que não há nada anterior à tradução. Reproduz-se a lógica sim/não diante da pergunta de Spivak: sim (eles são barulhentos) e não (eles não podem falar sem tradução). O que isso significa é que sem tradução o zapatismo não poderia sozinho e em seus próprios termos causar fissuras nas condições que definem a articulação hegemônica de significações, reduzindo a sua linguagem a um puro fora sem condições de impor condições. Assim, esse silêncio se torna diferença apenas no que tange à sua exterioridade à fala, ou seja, à sua traduzibilidade inerente. Nessa linha analítica não há preocupação em compreender a forma da linguagem zapatista que contesta não somente o silêncio, mas a própria forma da fala que o constitui como silêncio a priori. Sobra então apenas o gesto bem-intencionado de decodificar o silêncio subalterno em fala hegemônica - a pura voz da democracia. A economia hegemônica da significação se mantém, portanto, intacta, fundamentada sobre a oposição fala/silêncio, e a política zapatista se limita a interagir e afetar desde dentro da articulação dominante, não restando espaço para imaginar a suspensão da hegemonia que revela the irruptive - radically illiterate - void within signification itself. O silêncio não representa nem a incommensurate utterance of 'truth' as exteriority, nor the name of its authentic embodiment; a sua potência reside, portanto, muito além das articulações hegemônicas-contrahegemônicas do par silêncio/fala. Voltando a Nancy, perhaps it is necessary that sense not be content to make sense (or to be logos), but that 
it want also to resound. O silêncio, então, não mais compreendido como exterioridade à fala, contesta a definição dos objetos políticos e reconfigura os termos da situação da fala sobre a qual se governa. Agamben nos lembra de que o não-linguístico só pode ser encontrado dentro da própria linguagem, o que significa que a potência da irrupção do EZLN não pode simplesmente ser determinada pela escolha entre barulho e fala. Para Rancière é à polícia que cabe a realização dessa escolha. O político, por sua vez, está precisamente na disputa que desestabiliza a possibilidade de determinação das fronteiras entre uma coisa e outra: the problem is knowing whether the subjects who count in the interlocution 'are' or 'are not,' whether they are speaking or just making noise. It is knowing whether there is a case for seeing the object they designate as the visible object of the conflict. It is knowing whether the common language in which they are exposing a wrong is indeed a common language. The quarrel has nothing to do with more or less transparent or opaque linguistic contents; it has to with consideration of speaking beings as such.

O que há, na verdade, é uma abertura à outra linguagem, não no sentido de outra língua, apenas, que se constitui desde dentro da divisão entre o que é linguagem e o que não é, condicionando o surgimento de um reordenamento semiótico. Ao colidir a divisão entre dentro e fora, há a possibilidade de aceder a uma posição política que escapa à lógica da matriz da soberania e o estado de exceção sobre a qual ela se ancora: the state of exception is neither external nor internal to the juridical order, and the problem of defining it concerns precisely a threshold, or a zone of indifference, onde inside and outside do not exclude each other but rather blur with each other. Propõe-se uma recusa ao poder e cria-se, retomando Benjamin, um verdadeiro estado de exceção, verdadeiro porque não se impõe, conjuntamente a ele, a soberania: 
si el ser consecuente es un fracaso, entonces la incongruencia es el camino del éxito, la ruta al Poder. Pero nosotros no queremos ir para allá. No nos interesa. En esos parámetros preferimos fracasar que triunfar. (2014).

O EZLN subtrai-se, portanto, da configuração que a ordem formal da democracia adota no México e articula-se como uma proposta política que não se coloca meramente em oposição à hegemonia, mas para além dela.

El 21 de diciembre del 2012, cuando la política y el esoterismo coincidían, como otras veces, en predicar catástrofes que siempre son para los de siempre, los de abajo, repetimos el golpe de mano del 1 de enero del 94 y, sin disparar ni un solo tiro, sin armas, con nuestro solo silencio, postramos de nuevo la soberbia de las ciudades cuna y nido del racismo y el desprecio.

Si el primero de enero de 1994, miles de hombres y mujeres sin rostro atacaron y rindieron las guarniciones que protegían las ciudades, el 21 de diciembre del 2012 fueron decenas de miles que tomaron sin palabras los edificios desde donde se celebraba nuestra desaparición.

El sólo hecho inapelable de que el EZLN no sólo no se había debilitado, mucho menos desaparecido, sino que había 
crecido cuantitativa y cualitativamente hubiera bastado para que cualquier mente medianamente inteligente se diera cuenta de que, en esos 20 años, algo había cambiado al interior del EZLN y de las comunidades.

Tal vez más de alguno piense que nos equivocamos al elegir, que un ejército no puede ni debe empeñarse en la paz.

Por muchas razones, cierto, pero la principal era y es porque de esa forma terminaríamos por desaparecer.

Tal vez es cierto. Tal vez nos equivocamos al elegir cultivar la vida en lugar de adorar a la muerte.

Pero nosotros elegimos no escuchando a los de afuera. No a quienes siempre demandan y exigen la lucha a muerte, mientras los muertos los pongan otros.

Elegimos mirándonos y escuchándonos, siendo el Votán colectivo que somos.

Elegimos la rebeldía, es decir, la vida. (2014).

Escolher rebeldia ao poder pode parecer um gesto frágil e inocente, mas somos muito rápidos em confundir generosidade com inocência. Ao recusar os termos da disputa pelo poder, sempre demandados pelos que estão de fora, e sem abrir mão de resistir a ele, surge, justamente dessa tensão, a possibilidade de imaginar a política, não em seu consenso - a vida comum -, mas em seu dissenso - a vida em comum. De acordo com Gareth Williams, referindo-se a La Otra Campaña: as the EZLN proposes, this is a 
campaign not for electoral victory (that is, not for hegemony, counterhegemony, consensus or homogeneity) but for a life-giving communication in the wake of ruin. 0 que esperar daqueles que não querem poder? Que não disputam - a partir do dissenso - a posição de manter o consenso? Que disputam apenas - e isso já é muito - a abertura do dissenso ao incalculável? Não se trata de tornar o estado mais inclusivo ou mais eficiente porque ele reconhece e regula os direitos. A dificuldade de criar um antídoto para uma força política que não demanda nem a guerra, nem a negociação, torna a fragilidade uma possibilidade de escapar por uma linha de fuga.

Vimos que nuestro silencio fue escudo y espada que hirió y desgastó al que la guerra quiere y guerra impone. Vimos que nuestro silencio hizo resbalar una y otra vez a un poder que simula paz y buen gobierno, y que su poderosa máquina de muerte una y otra vez se estrelló contra el silencioso muro de nuestra resistencia. Vimos que en cada nuevo ataque menos ganaba y más perdía. Vimos que no peleando peleábamos. Y vimos que la voluntad de paz también callando se afirma, se muestra y convence. (1998).

Como o personagem Marcos - visto para que o que interessa não seja visto -, o silêncio - ao se desdobrar como fala inlocalizável - neutraliza, com as próprias exigências e termos que os poderes constituídos colocam, a máquina de captura e constrói, a partir da anulação dessa força externa, um espaço para renunciar ao pacto 
da soberania. Não há fins definidos para a campanha, embora haja uma direção, e, muito menos do que a paralisia, o que se revela é um mecanismo aberto sempre à necessidade de, segundo Gareth Williams, uma absolutely unconditional critique of the grounds of sovereign power. Ao inscrever a partilha da voz através do silêncio, o EZLN torna audível a impossibilidade do par silêncio/fala como fundação sobre a qual pode ser construída a democracia. Em vez da consolidação de uma forma de vida biopolítica, no sentido de adicionar mais biopolítica a essa forma que já existe como polícia, há a aparição de uma possibilidade de diferir de si mesmo enquanto subalterno dessa política constituída, que redefine o processo político em que a palavra democracia é ao mesmo tempo adversária e promessa incondicional para uma nova fundação do viver em comum. 
4. feminicídios ${ }^{30} /$

Y sus voces, las ha oído alguna vez?, dijo Sergio. Muy pocas veces, pero alguna vez sí que los he escuchado hablar. ¿Y qué dicen, Florita? No lo sé, hablan en español, un español enrevesado que no parece español, tampoco es inglés, a veces pienso que hablan en una lengua inventada, pero no puede ser inventada puesto que entiendo algunas palabras, así que yo diría que es español lo que hablan y que ellos son mexicanos, sólo que la mayor parte de sus palabras me resultan incomprensibles.

O ensaio La escritura en el cuerpo de las mujeres asesinadas en Ciudad Juárez, de

Rita Laura Segato, depois de um longo percurso analítico em torno das operações de significação e poder nos feminicídios de Ciudad Juárez, termina com uma consideração estarrecedora: Segato lembra que Édipo venceu a esLfinge, entendeu, conseguiu dar sentido, mas isso não o salvou de seu destino trágico. Escrevendo em 2006, a antropóloga considera o seu ensaio como o último na série de estudos dedicados a desvendar o que por muito tempo foi considerado como crimes em série ou como surtos de aparente aleatoriedade. Marcela Lagarde já em 1998 utiliza-se do termo feminicídio (criado por Diana Russel, na África do Sul, sob o nome de femicide) ${ }^{31}$ para referir-se ao conjunto sistemático de violências que vêm ocorrendo contra as mulheres de Ciudad Juárez desde 1993, o que em si já implicava o reconhecimento de que se trata de uma política ou um projeto oriundo de complexas dinâmicas de poder. O documentário Señorita Extraviada, de 2001, resgata os circos midiáticos montados em torno de prisões

\footnotetext{
${ }^{30}$ Agradeço imensamente à professora Susana Baéz Ayala, da Universidad Autónoma de Ciudad Juárez, sem quem não teria chegado às mulheres poetas de Ciudad Juárez.

${ }^{31}$ Para um resumo da discussão femicídio x feminicídio ver LAGARDE, M. "Del femicidio al feminicidio". In: Desde el jardín de Freud: revista de psicoanálisis. Número 6, 2006, p. 216-225.
} 
aleatórias de supostos assassinos seriais, como se o culpado fosse um indivíduo único que sofresse de um grave distúrbio mental ou moral, o mais famoso deles o egípcio Abdul Latif Sharif, um químico de uma maquiladora em cuja ficha já constavam dois crimes de estupro em território estado-unidense, condenado em 1996 por três assassinatos. Quando corpos de mulheres não pararam de aparecer nos lixões e terrenos balidos da cidade, mesmo após a sua prisão, criou-se uma história segundo a qual o egípcio coordenava uma gangue para que continuassem cometendo os assassinatos em seu nome. Como resultado disso, prenderam alguns jovens ligados ao narcotráfico. As mulheres de Ciudad Juárez não pararam de morrer. Na verdade, desde o início da década de 90, quando os feminicídios em Ciudad Juárez começaram a ser contabilizados e publicizados, o mapa da violência contra a mulher tem visto o epicentro mudar de lugar, sendo agora outros os estados que mais concentram crimes desse tipo, como o Estado de México, Veracruz, Guerrero e Michoacán, nos rastros dos fluxos econômicos (formais e informais, lícitos e ilícitos). Segundo consta no relatório da Anistia Internacional ao Departamento Interamericano de Direitos Humanos de 2009 sobre os feminicídios em Ciudad Juárez (focado especificamente nos feminicídios que ficaram conhecidos como o caso do Campo Algodonero ${ }^{32}$ ), a pesar de haber identificado a al menos 177 funcionarios estatales posiblemente implicados en investigaciones deficientes de mujeres asesinadas en la ciudad, las autoridades nunca llevaron a juicio a ninguno de ellos.

\footnotetext{
${ }^{32}$ Em novembro de 2001, 8 corpos foram encontrados em um terreno dedicado ao cultivo do algodão, destes, apenas 3 foram identificados à época: Claudia Ivette González Banda, Laura Berenice Ramos Monárrez e Esmeralda Herrera Monreal. As famílias levaram o caso à Comissão Interamericana de Direitos Humanos, que sentenciou o estado mexicano a cumprir uma série de medidas.
} 
Há uma narrativa mais ou menos consensual a respeito dos feminicídios em Ciudad Juárez. Essa narrativa afirma que os feminicídios aumentam exponencialmente a partir da assinatura do tratado da NAFTA, em 1993, o que transforma a cidade fronteiriça de Ciudad Juárez na "capital do emprego", com a implementação de maquiladoras, plantas industriais que funcionam quase exclusivamente com mão de obra feminina (a utilização dessa mão de obra se justificaria por dois fatores; primeiro o pressuposto de que mulheres estão mais aptas ao trabalho de montagem de pequenas peças delicadas, segundo o fato de que as dinâmicas trabalhistas perversas permitem que mulheres recebam menos dinheiro em troca do mesmo serviço). A criação de milhares de postos de emprego, além de trazer milhares de migrantes das zonas mais pobres do México (ainda mais empobrecidas pelo colapso da economia agrária) e inclusive da América Central, também desestabilizou as estruturas normativas da constituição familiar em que tradicionalmente é o homem que trabalha fora de casa e traz grande parte da renda doméstica. A independência econômica feminina (ainda que relativa, dada à precariedade das condições de trabalho), uma afronta à organização social patriarcal, aliada ao fato de que, de acordo com os termos do NAFTA, as empresas (grande parte delas estados-unidenses) não precisariam pagar impostos à cidade e, portanto, não contribuíam com a receita municipal para a implementação de melhorias urbanísticas que garantissem a segurança dessas mulheres que moram em bairros afastados (como iluminação, transporte público, periferias integradas à malha urbana), tornaram Ciudad Juárez naquilo que se convencionou chamar de "capital mundial do estupro". Além disso, com a chegada massiva de capital estrangeiro, a especulação imobiliária opera de tal forma que imensos lotes vazios são mantidos vazios por investidores, criando zonas desertas no meio da cidade no deserto. A equação seria 
mais ou menos a seguinte: homens desempregados (ou empregados informalmente, seja no narcotráfico, seja em outras áreas) + mulheres precariamente empregadas + ausência de medidas de segurança voltadas à mulheres que se deslocam nos horários determinados pelos seus turnos (noite/madrugada) + machismo estrutural $=$ feminicídio. Isso sem levar em consideração a fragilização das normas de condutas resultantes de um complexo sistema de justiça comunitária, ocasionada pelos modos de relação impostos pela escala do capital transnacional, suplantadas, então, pelo vazio da violência. A explicação contempla tanto os estupros e os assassinatos nas ruas quanto aqueles perpetrados no âmbito doméstico, estes que geralmente são contabilizados, absurdamente, como crimes passionais. Além disso, há uma série de estudos sobre a ineficácia da lei, sobre a impunidade, sobre a conivência e a responsabilidade de agentes do estado, tanto no que diz respeito à retenção de informação, quanto no que diz respeito à implicação direta nos casos - trata-se de uma rede que articula membros da elite econômica, da administração pública e da justiça local, provincial e federal.

Segato parte de todos esses pressupostos, compartilha deles, mas aponta que eles não dão conta de responder à pergunta sobre o sentido dos feminicídios. O sentido não se reduz a um conjunto de causas, por mais atreladas que elas estejam às suas consequências, o sentido é uma operação de outra ordem, pois precisa ser produzido. Contando sobre como, ao iniciar sua fala sobre os feminicídios em um canal de televisão local, o sinal de transmissão foi misteriosamente suspenso em Ciudad Juárez, Segato afirma, então: no olvidábamos que en Ciudad Juárez no parece haber coincidencias y, tal como intentaré argumentar, todo parece formar parte de una gran máquina comunicativa cuyos mensajes se vuelven inteligibles solamente para quien, por una $u$ otra razón, se adentró en el código. Es por eso que el primer problema que los horrendos 
crímenes de Ciudad Juárez presentan al forastero, a las audiencias distantes, es un problema de inteligibilidad. $Y$ es justamente en su ininteligibilidad que los asesinos se refugian, como en un tenebroso código de guerra. A sua hipótese é de que o feminicidio fala uma língua, isto é, constitui uma gramática cujo funcionamento serve à ordenação de um território sob um poder paralelo (ainda que ele conte com a cooperação, para isso, das omissões do governo estatal). Um parecer terrível emitido por um policial judiciário envolvido nas investigações dos crimes, um personagem em um livro de ficção diz: las mujeres son como las leyes, fueron hechas para ser violadas. O que Segato parece estar determinada a demonstrar é que a violação e subsequente assassinato dessas mulheres em realidade serve para produzir as leis desses grupos que se alçam na disputa violenta pelo poder nas instáveis dinâmicas de aliança e inimizade das redes dos cartéis de narcotráficos e de outros grupos de estruturação mafiosa que orbitam em torno dessas empresas-estado.

O ensaio da antropóloga em Ciudad Juárez não resulta especificamente de um trabalho de campo, não há uma confirmação por parte dos culpados de que o que está em jogo é a produção de leis internas, mas Segato conta com o resultado de uma pesquisa prévia sua, em que passou alguns anos pesquisando e conversando com homens presos por crimes de estupro na penitenciária de Brasília. Ela diz: mi "escucha" de lo dicho por estos presidiarios, todos ellos condenados por ataques sexuales realizados en el anonimato de las calles y a víctimas desconocidas, respalda la tesis feminista fundamental de que los crímenes sexuales no son obra de desviados individuales, enfermos mentales o anomalías sociales, sino expresiones de una estructura simbólica profunda que organiza nuestros actos y nuestras fantasías y les confere inteligibilidad. En otras palabras: el agresor y la colectividad comparten el 
imaginario de género, hablan el mismo lenguaje, pueden entenderse. A partir da constatação de que o estupro é uma ação sancionada e produzida por uma rede coletiva organizada pela masculinidade, Segato procura entender como os feminicídios de Ciudad Juárez se articulam para criar uma soberania para além da institucionalidade do estado, embora imiscuído nele, e, neste sentido, configura-se como uma violência que visa constituir uma relação de poder, cujos efeitos não se restringem ao corpo feminino mas dependem de situar esse corpo como um local importante da violência de modo a estender seu domínio para outras regiões.

A soberania completa diz respeito ao poder de morte em conjunção com a dominação da vida enquanto vida. A marca da soberania sobre os corpos não se restringe ao poder de morte sobre o subjugado, mas por sua derrota psicológica e moral, e a possibilidade de veicular essa derrota a uma audiência ampla: es por esto, diz Segato, que una guerra que resulte en exterminio no constituye victoria, porque solamente el poder de colonización permite la exhibición del poder de muerte ante los destinados a permanecer vivos ${ }^{33}$. Segundo a hipótese de Segato, portanto, os feminicídios seriam mortes de ordem expressiva - em oposição a mortes utilitárias/instrumentais - pois não resultam do combate direto da guerra ao tráfico ${ }^{34}$ ou da guerra entre o tráfico, mas dos códigos que administram a vida que ocorre sob o domínio dessas disputas territoriais.

\footnotetext{
${ }^{33}$ Ainda que seja importante matizar esta colocação, considerar que há conflitos e guerras cujo destino final é o extermínio, este realmente não é o caso para os feminicídios, pois as mulheres cumprem a função social de reprodutora dos meios de produção.

${ }^{34}$ Desde 2006, quando o governo federal do México adotou um programa de guerra às drogas, colocando a força nacional para combater os carteis mexicanos, o número de mortos e desaparecidos no México aumenta exponencialmente a cada ano, em grande parte homens jovens, diluindo a questão dos feminicídios em um cenário de violência muito mais amplo. Já há, por exemplo, quem diga que, no caso específico de Ciudad Juárez, falar ainda hoje em feminicídios é criar uma distração para os "verdadeiros crimes" cometidos tanto pelo narcotráfico quanto pelo estado, questionando de novo (ou ainda) a pertinência de um termo como feminicídio existir e ser respaldado pela lei. De acordo com The Femicide Machine, os números resultantes da guerra às drogas em Ciudad Juárez entre os anos de 2006-2012 são: 116,000 abandoned dwellings, 80,00 small businesses shuttered, 10,000 orphaned children, and 200,000 families exiled.
} 
Essas mortes utilitárias também possuem, é claro, sua dimensão expressiva, mas o que Segato parece tentar demonstrar é que os feminicídios têm função exclusivamente expressiva, embora a opção por essa forma seja instrumental, fruto de um cálculo realizado diante do trânsito dos significados.

Sendo o estupro considerado desta forma como um enunciado, ele se dirige simultanemeante a vários intelocutores. De acordo com Segato, as mensagens são emitidas por meio de dois eixos de interlocução, e não apenas de um, como geralmente se considera, pensando exclusivamente na interação com a vítima. No eixo vertical ele fala com a vítima, e o discurso geralmente adquire dimensões punitivas, concedendo ao agressor o lugar de moralizador, ou de guardião da moral social, porque neste imaginário compartilhado, o destino da mulher é ser contida, disciplinada, reduzida. No outro eixo, no entanto, o agressor se dirige a seus pares, em múltiplas formas: solicita o ingresso na sociedade conformada pelos pares e, desde essa perspectiva, a mulher violada ocupa o lugar de uma vítima sacrificial imolada em um ritual inciático; compete com eles, mostrando que merece, por sua agressividade e poder de morte, ocupar um lugar na irmandade viril e ser promovido a uma posição destacada de uma fraternidade que só reconhece a linguagem hierárquica ${ }^{35}$. Los interlocutores privilegiados en esta escena son los iguales, sean éstos aliados o competidores: los miembros de la fratría mafiosa, para garantizar la pertenencia y celebrar su pacto; los antagonistas, para exhibir poder frente a los competidores en los negocios, las autoridades locales, las

\footnotetext{
${ }^{35}$ Em Cruel Modernity, Jean Franco menciona que o cartel La Familia Michoacana pagou para que o livro Wild at Heart: Discovering the Secret of a Man's Soul, do escritor cristão John Elderedge fosse distribuído nas escolas rurais do estado de Michoacán. O livro propõe que a masculinidade torna o homem mais próximo de Deus pois isso Ihe concede a possibilidade de intervenção e resolução. Embora o livro não defenda a violência, o homem verdadeiro é compreendido como aquele que é guerreiro e selvagem, corajoso e implacável.
} 
autoridades federales, los activistas, académicos y periodistas que osen inmiscuirse en el sagrado dominio, los parientes subalternos - padres, hermanos, amigos - de las víctimas. Estas exigencias y formas de exhibicionismo son características del régimen patriarcal en un orden mafioso.

Aqui é possível traçar algumas relações com o livro Capitalismo Gore, de Sayak Valencia, professora do El Colegio de la Frontera Norte, campus de Tijuana, que busca os motivos pelos quais - além da violência absurda que já é o estupro seguido de assassinato - é tão comum que se encontrem sinais dos piores tipos de tortura, como queimaduras, mutilações e desfigurações. Ainda que o enfoque não seja explicitamente os feminicídios de Ciudad Juárez, nem apenas os feminicídios em si, Sayak Valencia procura compreender essa violência gore, isto é, esse gênero de ultra-violência masculinista que, embora muitas vezes seja lida como uma forma mais primitiva de violência, diz respeito ao próprio produto subalterno da violência capitalista e moderna, uma espécie de evolução inesperada da violência higienizada dos campos de concentração nazistas ou o revés dos assassinatos robotizados dos drones. Ela utiliza o termo "necroempoderamento" para falar dos processos que transformam contextos e/ou situações de vulnerabilidade e/ou subalternidade em possibilidade de ação e autopoder, reconfigurando esses quadros a partir de práticas distópicas e a partir da autoafirmação perversa alcançada por meio de práticas violentas rentáveis dentro das lógicas da economia capitalista: cuerpos concebidos como productos de intercambio que alteran y rompen las lógicas del proceso de producción del capital, ya que subvierten los términos de éste al sacar del juego la fase de producción de la mercancía, sustituyéndola por una mercancía encarnada literalmente por el cuerpo y la vida humana, a través de técnicas predatorias de violencia extrema como el secuestro o el asesinato por encargo. 
Como sugere Ursula Biemann em algum momento de seu filme Performing the border (1999): a desmembragem dos corpos femininos como respostas perversas aos repetitivos e destrutivos processos de montagem das maquiladoras (disassembly of bodies in the backyards of assembly lines). Não é à toa que a maior parte das mulheres encontradas mortas estão jogadas em lixões ou em terrenos baldios, muitas sem identificação, onde tornam-se refugo como todo resto, e como quase todo o lixo que as cerca, já foram produzidas como refugo, dada a sua descartabilidade. Sérgio González Rodríguez, em The Femicide Machine, sugere que as maquiladoras de Ciudad Juárez cumprem a mesma função biopolítica que os campos de concentração do Terceiro Reich: the opaque factory would be, at its extreme, the femicide machine's antechamber, an exceptional 'camp', as described by Agamben, o início da expropriação do corpo feminino. Nesse sentido, Segato também não considera que o motivo principal pelos crimes é o ódio contra as mulheres, embora ela não descarte a presença de misoginia como marca cultural da região, pero estoy convencida de que la víctima es el desecho del proceso, una pieza descartable, y de que condicionamientos y exigencias extremas para atravesar el umbral de la pertenencia al grupo de pares se encuentran por detrás del enigma de Ciudad Juárez.

A perversidade maior desse descarte, no entanto, é que somente a violência, e o laudo que o segue, materializa o corpo feminino - nesse sentido, encontrar o corpo efetivamente significa deparar-se com a existência de um corpo feminino -, e que a epistemologia a que está condicionada a compreensão do que constitui um corpo político (não apenas um corpo erótico, genitalizado) funciona de tal forma que o corpo feminino só se torna evidente no momento em que está sujeito ao crime ou à violência. 
No livro, Bodies that Matter, Judith Butler fala sobre a relação entre a materialidade e a inteligibilidade de um corpo: to speak within these classical contexts of bodies that matter is not an idle pun, for to be material means to materialize, where the principle of that materialization is precisely what "matters" about that body, its very intelligibility. In this sense, to know the significance of something is to know how and why it matters, where "to matter" means at once "to materialize" and "to mean". Pensando com Segato, então, as regras coletivas patriarcais e neoliberais em força nesta zona fronteiriça determinam que os corpos femininos podem significar somente no momento em que são produzidos e materializados nas formas das mulheres encontradas mortas, dando sequência à cadeia de mensagens na rede comunicativa.

A impunidade, evidentemente, cumpre uma função chave, mas não, diz Segato, exatamente da forma como costumamos imaginar. Geralmente compreende-se a impunidade como a causa principal para crimes que se repetem ao longo das décadas, mas é justamente o fato de eles se repetirem ao longo das décadas que pode levar à conclusão de que os feminicídios são cometidos em Ciudad Juárez para produzi-la e reproduzi-la como o seu efeito máximo: se dirige con esto a los otros hombres de la comarca, a los tutores o responsables de la víctima en su círculo doméstico y a quienes son responsables de su protección como representantes del Estado; le habla a los hombres de las otras fratrías amigas y enemigas para demostrar los recursos de todo tipo con que cuenta y la vitalidad de su red de sustentación; le confrma a sus aliados y socios en los negocios que la comunión y la lealtad de grupo continúa incólume. Les dice que su control sobre el territorio es total, que su red de alianzas es cohesiva y confable, y que sus recursos y contactos son ilimitados. Essas sentenças são, portanto, sentenciadas sempre que é necessário demonstrar poder: quando se consolida um novo 
grupo armado; quando se planeja uma transação ameaçado pelo perigo na fronteira patrulhada; quando há a chegada de um novo membro; quando outro grupo armado desafia o controle pelo território ${ }^{36}$. Essa língua falada através do feminicídio torna-se a língua franca do local, funcionando de maneira eficaz tanto para quem a fala quanto para quem não participa diretamente da ação enunciativa: es por eso que, cuando un sistema de comunicación con un alfabeto violento se instala, es muy difícil desinstalarlo, eliminarlo. La violencia constituida y cristalizada en forma de sistema de comunicación se transforma en un lenguaje estable y pasa a comportarse con el casi automatismo de cualquier idioma.

O automatismo do idioma que gera a sua própria imunidade é o destino do qual Édipo não pode escapar, mesmo havendo desvendado os termos da esfinge. Compreender o funcionamento de uma rede de códigos não é o suficiente para impedir a sua ação. Não é muito animador isso que Segato tem a nos dizer ao fim de seu ensaio. E, no entanto, considerando a possibilidade de que haja um cessar-fogo, a implementação de uma espécie de acordo de paz, ainda fica a sua pergunta sobre a justiça: ¿Si nos dijeran que la única salida es un armisticio, sería yo, serían ustedes, capaces de aceptarlo? ¿Y seríamos capaces de no aceptarlo?

$$
/ / /
$$

As mulheres também participam do jogo de produção de sentido, criam seus próprios códigos. A forma mais evidente são as cruzes rosas colocadas nos locais onde foram encontradas mulheres mortas. Mas também pintadas nas paredes e nos chãos dos lugares em que foram vistas pela última vez. Há uma batalha constante pela

\footnotetext{
${ }^{36}$ Os números para assassinatos, sequestros e feminicídios diminuíram significativamente entre os anos de 2013-2015, mas a prisão de El Chapo, chefe do Cartel do Pacífico, em 2016 vem novamente tencionando a fronteira em torno de uma reordenação do território.
} 
memória e contra as autoridades mexicanas, que apagam e removem as cruzes em nome da boa imagem da cidade, como para a ocasião da passagem do Papa Francisco pela cidade em 2016. Surgidas em Ciudad Juárez, as cruzes rosas, com a sua dimensão ao mesmo tempo imagética e territorial, passaram a simbolizar no México inteiro e em outros países da América Central a ubiquidade dos feminicídios.

A inclusão da palavra feminicídio no vocabulário corrente e a sua tipificação no âmbito jurídico é também uma importante conquista na guerra dos códigos. Em 2007, o estado de Chihuahua implementou a Ley Estatal del Derecho de la Mujeres a una Vida Libre de Violencia, mas referências a violência feminicida entre as outras formas de violência contra a mulher só foram incluídas em 2010, em função de um decreto. Porém apenas muito recentemente, em setembro de 2017, tipificou-se o feminicídio no Código Penal do estado de Chihuahua. Se a impunidade descrita nas páginas acima sugere que a tipificação do crime não necessariamente levará à condenação e sentenças, é possível pensar nos outros sentidos da lei. A lei pode funcionar aqui como uma espécie de potência discursiva que valida a influência de um sujeito coletivo que nela consegue representar-se, ainda que não se possa alcançar uma relação direta de causa e efeito entre leis e práticas. A palavra feminicídio pode dar algum poder às mulheres no terrível sistema de mensagens operante em Ciudad Juárez. Segato, em outro texto, "Femigenocidio como crimen en el fuero internacional de los Derechos Humanos", diz que abordada desde este ángulo, la lucha por el derecho se muestra próxima a lo que algunos autores han llamado el "derecho a narrar", porque el acceso a la inscripción de la demanda de un sujeto colectivo constituido por intereses comunes es también, y sobre todo, el derecho a narrarse en el discurso maestro sobre la nación que es el discurso jurídico. 
Essa formulação que coloca à frente a narratividade da lei e o direito de reivindicar uma posição enunciativa no discurso-mestre da nação torna-se particularmente relevante no caso de Ciudad Juárez, onde um dos primeiros importantes documentos sobre os feminicídios foi produzido em uma oficina de produção literária. Publicado em forma de livro, sob o nome El silencio que la voz de todas quiebra, seu gênero é indefinido, variando entre gráficos e tabelas, ensaios e biografias literárias, e foi escrito por sete mulheres (Rohry Benítez, Adriana Candia, Patricia Cabrera, Guadalupe de la Mora, Josefina Martínez, Isabel Velázquez, Ramona Ortiz) no S Taller de Narrativa de Ciudad Juárez. Assumindo o papel de pesquisadoras, detetives e escritoras, elas explicam o seu documento assim: trazamos el esquema de investigación pensando en una presentación tipo "collage" que llevaría al lector desde la fría e irrefutable realidad que produce el análisis de las características comunes del crimen, por ejemplo, hasta las conmovedoras vidas y aspiraciones de una niña de 13 años. De tal manera que el libro está ahora constituido por dos vertientes entrelazadas: todos los ensayos y análisis acerca del entorno policiaco, social y económico están basados totalmente en hechos probados, trabajo de hemeroteca, investigación bibliográfica, documentos de diversas organizaciones e instituciones, entrevistas y trabajo periodístico.

De fato é a primeira investigação nesta escala realizada sobre os feminicídios as mulheres da oficina de narrativa, no ano de 1998 , decidiram buscar nos jornais, nos tribunais, nas repartições públicas, nas delegacias e também nos necrotérios dados referentes aos assassinatos de mulheres. Também contaram com o trabalho prévio da Subprocuradoria de Justiça, que havia reunido dados estatísticos sobre os feminicídios (embora o título do documento seja "Homicidios en prejuicio de mujeres que han 
causado indignación en los diferentes niveles sociales de la comunidad 1993-1998"), além da disponibilização de material pelo programa de estudos de gênero da UACJ, do Comité Independiente de Chihuahua Pro-defensa de los Derechos Humanos e do coletivo feminista "Ocho de marzo". Em meio a esse trabalho investigativo há sete textos literários - embora a presença deles ali já complique a própria noção do literário - cada um produzido por uma das autoras, que escrevem, respectivamente, acerca ou desde a perspectiva de uma mulher assassinada. Esses textos também são fruto de trabalho investigativo, pois foram escritos com base em entrevistas realizadas com familiares e amigos. Entre os gráficos há dados específicos sobre cor de pele das vítimas, cor de cabelo, ocupação, locais onde foram encontrados corpos, enquanto os ensaios atacam a questão desde uma perspectiva analítica, criticando a morosidade das autoridades, explicitando o modo como o machismo opera discursivamente na fala de políticos e jornalistas e refutando a possibilidade de que se tratam de crimes em série. Os textos sobre as sete mulheres surgem da necessidade de construir un libro de vida, no de muerte; de alguna manera contribuir a que las voces, las imágenes y sueños de Eréndira, Sagrario, Olga Alicia, Elizabeth, Adriana, Silvia Elena y Argelia, por lo menos, perduraran en usted y en nosotras. Ciudad Juárez debe ser recordado no solamente por sus muertas, sino también por las mujeres que viven una vida común, acaso como la de usted mismo, como la de su madre, la de su hermana o la de su hija. A ideia de que uma oficina de narrativa possa produzir um documento literário, isto é, algo que, dirigido também - aos órgãos públicos, se vale - também - da literatura para produzir o relatório de sua investigação, me interessa muito. Aqui, talvez, aquilo que muitas vezes se chama de "literatura de denúncia" parece ganhar maior complexidade no que diz respeito à 
"literatura" e também à "denúncia". Que poder teria a literatura, por exemplo, diante de uma corte de justiça?

Quando se fala em "literatura de denúncia" em certos círculos literários, é geralmente em razão de um juízo estético, um critério de valoração que atribui a essa forma de literatura um lugar menor. O raciocínio parece ser de que esta forma de literatura é insuficientemente literária, pois tem um sentido apenas, isto é, denuncia dizendo que denuncia, não esconde o rastro de sua referencialidade e toma dos lugarescomuns da linguagem o seu andamento. Resumidamente, o que caracteriza aquilo que é reduzido à categoria de "literatura de denúncia" é o pressuposto de que ali não há relação radical com a linguagem, nenhum questionamento de sua própria forma, nenhum aceno formal à história da literatura. Além disso há a compreensão de que as formas literárias escritas sob a urgência de um diálogo direto com o presente diminuem suas chances de sobrevivência no continuum das formas literárias supostamente universais e, por isso mesmo, duradouras. Elena Poniatowska, uma das mais reconhecidas autoras mexicanas, em um especial sobre Ciudad Juárez em três partes escrito para o jornal La Jornada no ano de 2000, se desculpa às autoras de El silencio que la voz de todas quiebra por não ter levado à sério o seu desejo de publicação e concede a elas uma entrevista: las autoras del libro "El silencio que la voz de todas quiebra" han padecido muchísimo no sólo con la investigación sino con la jugada final de la editorial "Planeta" que guardó su material y lo utilizó pero para otro libro, el de Víctor Ronquillo. Si en Ciudad Juárez los asesinatos continúan, no se encuentran los culpables y no hay castigo para ellos, si las muchachas que trabajan en las maquiladoras son tratadas como pañuelos desechables de "úsese y tírese", también las autoras se encontraron con un ambiente misógino hostil o de total indiferencia. Cuando me visitaron en el DF, yo misma 
tenía tantísimo trabajo y el tema de las muchachas muertas me pareció tan feo que las relegué para más tarde, decepcionándolas. Hoy, les pido una disculpa. Estoy segura de que involuntariamente contribuí al clima de misoginia con el que se toparon en la ciudad de México al presentar su manuscrito. Los temas del aborto, del maltrato a la mujer, del asesinato son dolorosos, y casi todos preferimos darle vuelta a la hoja.

-¿Qué piensan ustedes que van a lograr con este libro: "El silencio que la voz de todas quiebras. Mujeres y víctimas de Ciudad Juárez"?

O trecho é particularmente interessante porque a obra de Elena Poniatowksa é marcada pela polifonia de vozes e pela composição e montagem de entrevistas na construção de uma narrativa intermitente. Seu livro mais conhecido, La noche de Tlatelolco: Testimonios de historia oral, de 1971, contém entrevistas, excertos de jornal e poemas sobre o massacre de Tlatelolco em 1968. Este livro foi um dos primeiros a oferecer uma contranarrativa para a versão oficial contada pelo estado mexicano. A sua recusa em ajudá-las, portanto, dificilmente pode ser explicada pela escolha da estrutura do livro, mas algo por que ela descreve como o tema das mulheres mortas, que me pareció tan feo. A revelação de que a editora "Planeta" repassou o material para que Víctor Ronquillo, um jornalista de nota roja, escrevesse o seu livro Las Muertas de Juárez, coloca, no entanto, limites para isso que parece tan feo. O livro de Ronquillo toma a perspectiva dos agressores, relata vividamente sessões de tortura, constrói uma atmosfera de suspense, e omite os nomes das vítimas, dando continuidade à sua invisibilidade. A misoginia no meio literário, Poniatowska parece dizer, fixa as posições enunciativas, dá prosseguimento ao pacto e conforma os seus próprios códigos ao redor 
do qual é possível constituir a instituição literária ${ }^{37}$. No entanto, a pergunta com que ela

escolhe começar a entrevista: ¿Qué piensan ustedes que van a lograr con este libro?

indica as exigências que se faz para certo tipo de literatura que, se cuja função não é

literária, só pode ser medida em função de sua efetividade prática. E, então, por um

caminho tortuoso, faz-se a esse modo literário a mesma pergunta que se faz à lei, sem

levar em consideração seus outros efeitos possíveis.

O fato de que grande parte da literatura produzida pelas mulheres em Ciudad

Juárez sobre os feminicídios foi realizada em esforços coletivos e em situações de oficinas literárias deveria ser incontornável para qualquer gesto crítico. No livro Estética Relacional, Nicolas Bourriaud discute outras possibilidades para a arte: a possibilidade de uma arte relacional (uma arte que toma como horizonte teórico a esfera das interações humanas e seu contexto social mais do que a afirmação de um espaço simbólico autônomo e privado) atesta uma inversão radical dos objetivos estéticos, culturais e políticos postulados pela arte moderna. Em outros termos, as obras já não

\footnotetext{
${ }^{37}$ Cheguei ao México com uma pergunta sobre a produção literária feminina relacionada aos feminicídios de Ciudad Juárez, pois em minha pesquisa prévia só havia me deparado com nomes masculinos, entre eles grandes nomes da literatura latino-americana. Lá me deparei com um gênero que editorialmente e até academicamente vem sendo chamado de narcoliteratura, literatura de fronteira, e/ou literatura do norte. Dentro desse universo, Orfa Alarcón e Cristina Rivera Garza ofereceram uma espécie de pista, embora os feminicídios não sejam exatamente as questões de seus romances, sendo de qualquer forma interessantes os pontos de vista de protagonistas mulheres inseridas no universo de violência. Em Perra Brava, de Alarcón, a perspectiva narrativa é de uma universitária que é namorada de um temido sicário, enquanto no livro de Rivera Garza, La muerte me da, uma professora universitária encontra um corpo masculino castrado, um entre outros crimes, aparentemente em série, cometidos por uma mulher, poeta, leitora de A. Pizarnik, e investigados por uma detetive e uma periodista jornalista. Com Sangre en el desierto: las muertas de Juárez, escrito por Alicia Gaspar de Alba, um romance que conta a história de uma mulher que cruza a fronteira de El Paso para Ciudad Juárez para adotar o bebê de outra mulher, que trabalha em uma maquiladora, parecia chegar mais perto da questão. Quando esta última é assassinada, a mulher empreende uma investigação por conta própria e encontra um complexo emaranhado de relações de poder que se dedicam a promover e a ocultar os feminicídios. É interessante notar que todos os livros estão de alguma forma ligados à universidade, seja pelo currículo de suas autoras, pelas personagens, seja pela forma em que se questiona a literatura, ou também a priorização daquilo que eu aqui, com várias ressalvas, vou chamar de "questões teóricas", isto é, de questões que estão ligadas a algumas formas muito específicas de teoria, formas que circulam predominantemente no universo acadêmico.
} 
perseguem a meta de formar realidades imaginárias ou utópicas, mas procuram constituir modos de existência ou modelos de ação dentro da realidade existente, qualquer que seja a escala. A hipótese de Bourriaud é de que no lugar de descrever utopias, a arte relacional procura construir espaços concretos por meio de uma elaboração coletiva de sentidos: a obra de arte apresenta-se como um interstício social no qual são possíveis essas experiências e essas novas "possibilidades de vida": parece mais urgente inventar relações possíveis com os vizinhos de hoje do que entoar loas ao amanhã. É só, mas é muito.

Há pelo menos duas antologias poéticas produzidas ao redor dos feminicídios: Canto a una ciudad en el desierto (organizada por Juan Armando Rojas y Jennifer Rathbun em 2004, resultado de oficinas literárias realizadas em 2001 e 2002) e "Las muertas de Juárez", para uma edição temática da revista Metapolítica (2003). Uma das poetas publicadas, Susana Chávez, foi assassinada em 2011. Como dissociar esse assassinato dos poemas ali presentes, quase todos em tom elegíaco? Ou do poema de Antonieta Villamil, "Heridas de impunidad", que para tentar encontrar algum significado possível, parece recorrer a uma língua que nem parece mais ser o espanhol.

Mematarón.

Mematarón.

Mematarón.

(...)

Mematarón

ayyy yayayai

mematarón.

Nosénosé

porqué

mematarón.

(...)

Mematarón ayyy yayayi

mematarón. Me matarón.

Meeeeeeee maaaaaaa tarón. 
A elegia é também a forma escolhida por Micaela de Solís, em seu livro de poemas Elegía en el desierto (2004), poemas de muita dor, em geral sem saída, en esta ciudad de carniceros / aprenderé a llorar la muerte de un felino que perguntando sobre el viento misógeno que sopla / en algunos / buenos poemas / de algunos / de nuestros / buenos / poetas, provoca a instituição literária e seus critérios para a determinação de bons poemas e poetas. Arminé Arjona é outra poeta, autora do livro Juárez tan lleno de sol y desolado (2004) e é também grafiteira, pintando nos muros frases como: nadie sabe si Calderón nos ve como una muerta media llena o una muerta media vacía. A ironia, diferente da grande maioria das poetas das antologias, é bastante presente em seus poemas, Zona Residencial / cochera electrónica / 4 recámaras 3 baños / jacuzzi alfombrada / amplio patio / donde fácilmente caben /15 a 18 muertas, ainda que pareça impossível escapar da dramatização melancólica: en tu desierto / florece muerte / mujer y llanto / llanto y mujeres, ou ainda: y todos nos vamos / volviendo asesinos / con la indiferencia / con el triste modo / en que la juzgamos: / "gente de tercera" / "carne de desierto".

Uma questão que começou a delinear-se para mim em função dessas leituras refere-se aos modos possíveis de falar sobre os feminicídios: desde qual perspectiva e com vistas a quê? Por que o predomínio do tom elegíaco? Por que utilizar o espaço criativo de uma oficina de narrativas para perseguir dados e estatísticas? Por que pixar versos nos muros? Como imaginar-se no lugar dessas mulheres assassinadas, com que eu? Por que realizar a produção literária quase sempre em atividade coletiva? Por que recorrer à tragédia grega, despertar Antígona e levá-la a um necrotério de Ciudad Juárez (refiro-me aqui à peça Antigona; las voces que incendian el desierto, de Perla de la Rosa)? 
Não são perguntas menos literárias as que essas obras suscitam. E por isso cabem ainda outras perguntas. Em que medida esses poemas, que de modo geral vinculam-se em seus prefácios às noções de "denúncia", contra o "silenciamento", pela "humanização das vítimas", não são neutralizados pela repetição das imagens de sangue, de lágrimas, de ossos, de corpos, de paisagens hostis do deserto, das mães chorando; em que medida esses poemas corroboram as imagens da nota roja, alimentam um arquivo gigante de violências, que pelo seu crescimento exponencial acaba por tornar ineficaz o desejo de romper o silêncio, isto é, de tanto repetir-se já não tem efeito nenhum? Por outro lado, como não se repetir, como não dedicar, uma vez mais, um poema em memória dos feminicídios se a impunidade é a mesma há décadas, se as cenas dos crimes são as mesmas? E se a questão não for justiça, aparentemente inatingível, mas uma constituição, através da escrita, através da leitura, de uma rede de mulheres, da vida que surge interliterariamente em uma cidade onde o direito à vida está interditado ou encontra-se em estado muito precário? Talvez seja possível dizer que a produção literária de Ciudad Juárez, esta que surge como resultado de um encontro entre mulheres onde a possibilidade de escrever passa pela presença diante das outras, inventa e conforma um território onde é possível partilhar e fazer circular códigos com poder de vida.

A questão, evidentemente, passa pela ética e suas demandas, pelas demandas que a literatura e o mundo, porque não cessam de se contaminar, fazem um ao outro. Não se trata de negar a morte, a brutalidade e seus corpos, mas de perguntar-se o que fazer com esses elementos no momento em que eles se deslocam da cena do crime para assumir uma voz, um ponto de vista, uma vida própria, por assim dizer. Theresa Margolles, artista plástica mexicana cujo assunto principal de trabalho é a morte como 
sintoma de uma violência sistemática, que integrou por muito tempo o coletivo artístico SEMEFO (cuja sigla, na Cidade do México, quer dizer Serviço Médico Forense), realiza grande parte de suas obras a partir de materiais obtidos em necrotérios. Isso significa que esses materiais são, frequentemente, tecidos e órgãos humanos. Tanto o SEMEFO quanto Teresa Margolles já receberam duras críticas pelos seus métodos, desde aquilo que diz respeito à obtenção de corpos sem identificação, ou de corpos que não têm quem os retire, ambos reflexos dos circuitos da violência e pobreza, quanto no que diz respeito à sua utilização, desmembrada, desidentificada, recortada com um fim artístico, exposto em uma galeria. Sem a autorização de quem foi aquele corpo, e pensando principalmente em quem são esses corpos que estão disponíveis ali para qualquer coisa que não seja um ritual de despedida, as instalações parecem reincidir violentamente sobre esses mesmos corpos. Não é uma discussão fácil a questão de um ready-made de cadáver. Uma das obras mais famosas de Margolles é Vaporización (2001): nesta instalação a água, recolhida de um necrotério após ter sido utilizada para lavar os cadáveres, é vaporizada, contaminando de morte, por assim dizer, quem passa pela sala. Nesta obra a questão não parece ser tangibilizar a morte e a violência pela produção de um corpo como prova, mas discutir a sua ubiquidade, implicar todos no ato da morte, do assassinato. Irrigación, de 2010, é um vídeo em que um caminhão-pipa viaja por uma estrada no Texas com os registros abertos, filmado por trás, a partir de um outro carro em movimento, o caminhão derrama o que parece ser água limpa, mas é em realidade água misturada aos dejetos coletados de algumas cenas de crime em Ciudad Juárez. Uma implementação de uma espécie de política de reciprocidade, a irrigação do deserto estadunidense com restos mortais como um comentário sobre pacotes de desenvolvimento que na verdade são projetos de destruição, um aceno ao 
maior mercado de consumo de drogas do planeta. Em 2012 parece haver um gesto em outra direção, e com La Promesa os materiais passam a ser constituídos por outras formas de resíduos, resíduos que ainda resultam do testemunho da violência, mas não são mais orgânicos. Em La Promesa, uma casa abandonada em Ciudad Juárez por uma família que se viu forçada a partir depois do assassinato da filha é destruída por Margolles, que transforma as 22 toneladas de escombros, pulverizados, em uma grande escultura. Exposta em um museu, os visitantes eram convidados a destruí-la. No lugar onde ficava a casa, ela construiu um centro de convivência comunitário. 
/5. animais\

Hay gente y también hay animales e incluso cosas que, por una u otra causa, a veces dan la impresión de querer esfumarse, de querer desaparecer.

Em "Encontros no fim do mundo", um filme sobre a Antártica, Herzog pergunta a um pesquisador se haveria algo como a insanidade entre os pinguins. O campo da cena se abre para uma vasta superfície branca, uma escala de paisagem assombrosa, em que é possível ver um pequeno grupo de pinguins correndo da colônia em direção ao mar. Um pinguim chama atenção no meio do plano, pois interrompe o seu movimento e, no lugar de voltar para a colônia ou seguir para o mar com os outros, começa a correr continente adentro, a câmera fechando o ângulo sobre a sua corrida estranha de pinguim e abrindo de novo, com maior amplitude, mostrando esse pinguim solitário correndo em direção às montanhas, rumo à vastidão do gelo. O pesquisador explica que mesmo que fosse trazido de volta à colônia, ele imediatamente voltaria a correr na direção das montanhas. Na trilha sonora, um coral canta, a cappella, uma música litúrgica da igreja ortodoxa russa composta no século XVIII.

Em Problemas de Linguística Geral, no capítulo intitulado “Comunicação animal e linguagem humana", Emile Benveniste determina, por meio da observação das abelhas, aquilo que, de uma vez por todas, demonstraria, segundo ele, a diferença entre os homens e os animais ${ }^{38}$. O título já é bastante denotativo da cisão central sobre a qual se estabelecem as categorias distintas, que, surpreendemente, não custa mencionar, são apenas duas, como se a diferenciação interna à humanidade e à animalidade fossem

\footnotetext{
${ }^{38}$ Segundo conta Eduardo Viveiros de Castro, de acordo com alguns ameríndios, no começo tudo teria sido humano, o mundo surgindo a partir da diferenciação em relação ao ser humano e não o contrário, sem que isso, no entanto, ocasionasse uma diferença irredutível.
} 
equivalentes em sua comparabilidade. De todo modo, o que é exposto ao decorrer do texto é que os humanos teriam desenvolvido a linguagem ao passo que os animais representados pela abelha - teriam desenvolvido apenas um código: aplicada ao mundo animal, a noção de linguagem só tem crédito por um abuso de termos. As abelhas foram escolhidas por suas capacidades organizativas dentro de um escopo coletivo, fazendo supor que têm aptidões para trocar verdadeiras mensagens, o que também quer dizer que a suposição sobre a possibilidade de existirem trocas de mensagens verdadeiras está diretamente relacionada à ideia que certo setor da espécie humana dedicada à ciência tem sobre o que pode constituir-se como uma organização coletiva. As abelhas, apesar de só existirem linguisticamente por um abuso de termos, também não deixam de constituir o horizonte de expectativas para uma forma de organização, com estruturas e funções muito claras em prol de sua reprodução, alimentação, controle interno e proteção a ameaças externas, a qual poderíamos melhorar na nossa condição de espécie humana, infinitamente dotada de poderes de destinação. Segundo Fabián Ludueña Romandini, lendo Aristóteles, o homem é chamado político simplesmente porque é o único animal que toma em seu encargo a direção consciente de sua própria zoé de acordo com os critérios do justo e do injusto. Mas isso também quer dizer que o animal político é resultado da domesticação do animal humano. Marx pressupõe o trabalho sob forma exclusivamente humana (i.e. o trabalho como essência do homem), segundo explica, porque o pior arquiteto se distingue da melhor abelha por "figurar" na mente sua construção antes de transformá-la em realidade. No fim do processo do trabalho aparece um resultado que já existia antes idealmente na imaginação do trabalhador. Ele não transforma apenas o material sobre o qual opera; ele imprime ao material o projeto que tinha conscientemente em mira, o qual constitui a lei 
determinante do seu modo de operar e ao qual tem de subordinar sua vontade. Em 2001, Uma Odisseia no Espaço, na cena inaugural da humanidade, a lógica é bastante similar - não basta a ferramenta, o fêmur na mão, batendo no resto da carcaça, é preciso conseguir imaginar - figurar - o fêmur sendo utilizado em um animal vivo, que viria, então, a morrer. As abelhas, como se sabe, vêm morrendo aos milhares - as melhores abelhas perdendo a batalha para os piores arquitetos. Das espécies extintas, guardamos figuras.

Na pesquisa sobre a linguagem das abelhas, a atenção dos observadores dirigiuse particularmente para a maneira pela qual as abelhas são avisadas quando uma dentre elas descobre uma fonte de alimento. Uma abelha exploradora, ao encontrar algo, consegue voltar à sua colmeia e indicar, por meio de danças - uma consiste em traçar círculos horizontais da direita à esquerda, depois da esquerda à direita sucessivamente, a outras, acompanhada de uma vibração contínua do abdômen, imita mais ou menos a figura de um 8-, o local de origem do alimento. Sem que a primeira abelha vá junto, as outas abelhas, como se munidas de um mapa, conseguem chegar ao local indicado. Essa segunda leva de abelhas, ao retornar de sua missão, encena novas danças, o que provoca novas partidas, assim sucessivamente. Essas mensagens comportariam duas informações distintas - uma sobre a distância, outra sobre a direção. Até aqui encontramos, nas abelhas, as próprias condições sem as quais nenhuma linguagem é possível - a capacidade de formular e de interpretar um 'signo' que remete a uma certa 'realidade', a memória da experiência e a aptidão para decompô-la. As aspas em "signo" e "realidade" são bastante significativas, pois não está muito certo se a instabilidade é inerente a esses conceitos, ou se as aspas se devem a sua inadequação para o caso animal. De acordo com Benveniste, haveria um simbolismo verdadeiro embora 
rudimentar, pelo qual dados objetivos são transpostos em gesto formalizados, que comportam elementos variáveis e de 'significação' constante ${ }^{39}$. Ele também enumera, porém, quatro diferenças capitais: a) a mensagem é veiculada por meio da dança, e não existe linguagem sem voz/ b) sendo a comunicação gestual, ela só é possível sob a luz do dia/ c) não haveria resposta à mensagem, ou seja, não há comunicação dialógica/ d) por último, as abelhas não poderiam retransmitir a mensagem: a mensagem de uma abelha não pode ser reproduzida por outra que não tenha visto ela mesma os fatos que a primeira anuncia - dito de outro modo: as abelhas não saberiam citar. As primeiras três diferenças, ao que tudo indica, são facilmente desmontáveis - como resposta ao primeiro caso, poderíamos pensar na linguagem de sinais (e é interessante, inclusive, que ao fim do texto Benveniste afirma que as abelhas não possuem linguagem, mas um código de sinais); ao segundo caso bastaria dizer que, embora a ausência de luz não seja uma limitação humana àqueles que não se utilizam de Libras, o ruído excessivo seguramente impede a nossa comunicação oral ${ }^{40}$ - além disso, dentro das colmeias não há luz, o que indica que a dança não é percebida visualmente; por último, me parece

\footnotetext{
39 Jacob von Uexküll foi um biólogo holandês bastante excêntrico do início do século XX. Frente à fisiologia mecanicista que dominava o horizonte científico da época, ele se dedicou à convicção de que cada ser vivo possui o seu próprio espaço e tempo subjetivo, o que ele veio a chamar de doutrina do mundo-próprio. Segundo a sua "Doutrina do Significado" - dedicado aos meus adversários em Ciência, para que usem de amigável atenção - todo sentido é co-textual. Essa co-textualidade determina, a cada vez, uma função e é somente em função da função que um sentido pode ser atribuído: o mesmo pedúnculo de uma flor desempenha, conforme o cenário do mundo-próprio em que se encontra, o papel de adorno, de passagem, de reservatório ou, finalmente, de bocado de comida. Isto é verdadeiramente espantoso. Logo que cada componente de um objecto orgânico ou inorgânico surge, como objecto significante, no cenário da vida de um sujeito animal, esse componente é posto em contacto com um, digamos, complemento, situado no corpo do sujeito que intervém como utilizador do significado.

${ }^{40} \mathrm{E}$, no entanto, lembro aqui que no documentário de Herzog há uma cena em que a equipe recémchegada à base McMurdo na Antártica passa por um treinamento de sobrevivência em condições climáticas adversas. As pessoas, então, colacam suas cabeças dentro de baldes (com rostos desenhados à caneta permanente) para simular situações de baixa visibilidade e tentam manter-se em um grupo coeso enquanto tentam encontrar um membro do grupo que se perdeu. Os resultados são desastrosos e dão o testemunho bem-humorado das limitações comunicacional e orientacional dos seres humanos científicos.
} 
difícil acreditar que deslocar-se em função de um dispositivo linguístico espacial não conte como resposta.

Em The animal that therefore I am, mais especificamente em "And Say the Animal Responded", Derrida discute a divisão animal/humano em Lacan por meio da divisão reação/resposta. Mais do que insistir que o animal pode sim responder, Derrida procura discutir o quanto de reação há naquilo que se convenciona compreender como resposta. Inclusive, se pensarmos desde a nossa possibilidade de citação infinita, além das possibilidades finitas de combinações sintagmáticas que permitam inteligibilidade, faz bastante sentido que haja pouco espaço para ineditismos nas respostas: especially when the logic of the unconscious is founded on a logic of repetition, which, in my opinion, will always inscribe a destiny of iterability, hence some automaticity of the reaction in every response, however originary, free, critical, and a-reactional it might $\mathrm{seem}^{41}$. As tentativas de diferenciar a linguagem humana da linguagem animal, de separá-las completamente como algo inferior e distinto há muito superado pela nossa espécie, terminam geralmente por desconsiderar o que as torna, justamente, muito semelhantes. As crianças no começo não falam, segundo escreve Daniel Heller-Roazen, emitem apenas ruídos que ao mesmo tempo em que antecipam a linguagem humana, habitam uma esfera completamente diferente. Neste momento, as crianças dispõem de

\footnotetext{
${ }^{41} \mathrm{O}$ papagaio propõe uma questão interessante: conhecido por suas habilidades de citação, sua linguagem não ocupa um lugar privilegiado dentro dos estudos da linguagem animal. Isso porque afirma-se que a linguagem do papagaio é externa a ele e, portanto, carente de significação. Ele cita, mas não sabe o que está citando. Por isso mesmo, no entanto, como repetidor de uma forma, faz o ser humano deparar-se com o aspecto mecânico e maquinal de sua própria fala. Em Vidas Secas, de Graciliano Ramos, o papagaio latia como resultado da ausência da fala humana. Em Zazie no metrô, de Raymond Queneu, o papagaio repete, insistentemente, falar, falar, você só sabe fazer isso. Em comunicado de 14 de fevereiro de 1997, o Subcomandante Marcos retoma La Vitoria del Perico, um texto de 1823 escrito pelo mexicano Fernández De Lizardi em que se conta uma história segundo a qual havia um papagaio que só sabia dizer vitória. $\mathrm{E}$ repetiu a palavra "vitória" incontáveis vezes, a cada vez que o gavião levava um de seus membros, seus olhos, suas penas. O papagaio termina por morrer gritando vitória. Assim terminarão os mexicanos, diz Lizardi, gritando "liberdade" enquanto o sistema político recrudesce e desmorona ao seu redor.
} 
poderes de fonação ilimitados, cujo balbuciar parecem conter em si o potencial de todas as línguas. Mas no caminho de aprendizado para a sua língua única, a criança parece esquecer todas as possibilidades ao restringir a sua capacidade de articulação vocal em direção ao sistema finito de consoantes e vogais que caracteriza uma língua específica. Os adultos, ele diz, retém algo dessas formas na sua linguagem madura, mas na forma de um echo of another speech and of something other than speech: an echolalia, which guarded the memory of the indistinct and immemorial babble that, in being lost, allowed all languages to be. Os exemplos mais evidentes dessa linguagem vestigial são as onomatopeias e algumas exclamações de nojo, dor, susto e tristeza. Nowhere is a language more "itself" than at the moment it seems to leave the terrain of its sound and sense, assuming the sound shape of what does not - or cannot-have a language of its own: animal sounds, natural or mechanical noises. Mas por que, ainda assim, os animais não têm linguagem própria?

Voltemos a Benveniste e à hipótese da citação como especificidade humana, com um rápido desvio por Barthes, que no início de $A$ Câmara Clara, afirma que a fotografia é conatural ao seu referente, isto é, tautológica; o seu referente sempre apenas o seu referente. Não seria, portanto, um signo, mas a coisa mesma; nos seus termos, uma mensagem sem código que não chegaria a constituir uma linguagem, portanto, pois não haveria marcas. O final da primeira parte, no entanto, já confirma o seu erro e ele prevê que a segunda parte do livro terá de lidar com esse erro, eu tinha de fazer minha palinódia. Como da fotografia, neste primeiro momento do livro, antes da morte de sua mãe, diz-se que a forma de comunicação da abelha é também autoidêntica, transmite o próprio referente e, portanto, sem ter havido contato com o referente, não há como o enunciado existir de forma independente do enunciador. Só 
tira a foto quem esteve lá. Às abelhas é interditado um ponto de vista, pois a única coisa que podem transmitir é a realidade, ou melhor, alguns dados sobre a realidade. A abelha, segundo Benveniste, não pode transmitir a própria transmissão, isto é, não transmite linguagem, não constrói uma mensagem a partir de outra mensagem. Cada uma das que, alertadas pela dança da primeira, saem e vão alimentar-se no ponto indicado, reproduz quando volta a mesma informação, não a partir da primeira mensagem, mas a partir da realidade que acaba de comprovar. Ora, o caráter da linguagem é o de propiciar um substituto da experiência que seja adequado para ser transmitido sem fim no tempo e no espaço, o que é o típico do nosso simbolismo e o fundamento da tradição linguística. É literalmente com esse tipo de raciocínio que as sondas espaciais Voyager 1 e Voyager 2, ambas não tripuladas, levaram como substitutos de seres humanos uma compilação de citações gravadas em um disco de ouro - fotografias e sons diversos - que supostamente serviriam como um cartão de visitas, caso a sonda fosse interceptada por outras formas de vida.

O que se insinua, portanto, dentro dessa leitura, é que as abelhas não teriam um meio de comunicação, pois a comunicação delas seria efetuada sem mediação, sem figuração, sem imaginação - o que esse código transportaria seriam apenas dados sobre a realidade e não a representação de uma ideia sobre a realidade. Sem passar pelo estágio da representação, não seria possível passar ao estágio seguinte - a representação da representação. Se, no entanto, como primeiro passo, propusermos, com Walter Benjamin, que a comunicação não comunica nada além de si mesma, ou seja, toda língua se comunica em si mesma, já seremos obrigados a uma primeira mudança de rumo. A linguagem desta lâmpada, por exemplo, não comunica a lâmpada (pois a essência espiritual da lâmpada, na medida em que é comunicável, não é em 
absoluto a própria lâmpada). Ainda que admitamos, por hora, dentro de uma lógica restrita, que a abelha não constrói uma mensagem a partir de uma mensagem, talvez não seja absurdo dizer que ela constrói uma realidade - um mundo próprio - a partir da mensagem (e não o contrário); é a dança da abelha que constitui uma distância e uma direção. A divisão ser humano/animal ou animal falante/animal não-falante pressupõe que aquele que detém o instrumento da fala também detém, por meio do instrumento, a natureza, olhando-a de fora, enquanto o animal pertence à natureza, estando preso em sua própria tautologia. Não seria, se não mais correto, pelo menos mais interessante dizer que ambos, produzem natureza e que a cultura, o cultivo, é só apenas um modo de produzir natureza? E, então, utilizando outro critério para determinar se haveria linguagem, seria interessante reformular a pergunta da seguinte forma: haveria polissemia, resíduo, a possibilidade de que a mensagem desviasse do intuito primeiro da mensagem ${ }^{42}$ ? A hipótese que pretendo desenhar é de que sim, desde que não falássemos mais no transporte da mensagem como condição da linguagem, mas da linguagem como aquilo que transporta um gérmen de realidade, uma possibilidade de realidade. A linguagem dá existência, anima - produz uma marca que constitui efeitos e afetos e não se limita à transferência estrita de um conteúdo semântico com um direcionamento claro; a transferência mais transforma do que transporta, ou transporta elementos de outra ordem. Gregory Bateson: "Information" may be succinctly defined as any difference which makes a difference in some later event. Para Simondon, a informação é uma função ativa que situa o sujeito no mundo. Como resultado do encontro entre flor e abelha - como resposta àquela dança, portanto - há sempre

\footnotetext{
${ }^{42}$ Como nem há intenção para os animais, não poderia haver desvio. Mas por outro lado, ao fim, mesmo à revelia, são os humanos que atribuem um sentido estritamente teleológico à vida dos animais sobreviver e reproduzir.
} 
disseminação, dispersão - sem garantias de polinização e fecundação. Hustak \& Myers: Like pollination, communication, expression, and articulation are practices through which organisms involve themselves in one another's lives.

Mas a questão parece ser sobre a própria questão que se faz aos animais. Elizabeth Costello, no livro homônimo de J.M. Coetzee, conta sobre as pesquisas de Wolfgang Köhler, um psicólogo que publicou em 1917 um trabalho chamado The Mentality of the Apes a serviço da Academia Prussiana de Ciências. Wolfgang Köhler was probably a good man. A good man but not a poet. Um poeta, ela diz, teria feito outras perguntas aos macacos. Em vez de focalizar o momento em que os chimpanzés se colocavam em círculo e começavam a dançar e a se vestir e brincar com os objetos disponívies na área de estudo, o psicólogo interessava-se apenas pela forma com que os chimpanzés utilizavam-se de objetos para obter bananas. Assim, o chimpanzé is driven to think the less interesting thought. From the purity of speculation (Why do men behave like this?) he is relentlessly propelled toward lower, practical, instrumental reason (How does one use this to get that?) and thus toward acceptance of himself as primarily an organism with an appetite that needs to be satisfied. Perguntas pouco criativas e respostas inócuas também são questões para Vinciane Despret em "O que diriam os animais se...". Os bons cientistas, segundo ela, sabem que não aprenderão nada de interessante sobre seus animais se não elaborarem questões suscetíveis a interessá-los. Boas perguntas tornam até os carneiros interessantes, animais geralmente considerados pouco complexos ${ }^{43}$. Os carneiros tornam-se complexos no

\footnotetext{
${ }^{43}$ Curiosamente, porém, para Platão, como aponta Fabián Ludueña Romandini, é justamente entre esses animais adestrados e desinteressantes, que está a possibilidade de política, o que justifica o pastoreio como tecnologia de poder: Assim, a ciência que perseguimos sempre esteve e permanece ainda entre os animais mansos e é entre os que vivem em rebanho que devemos buscá-la.
} 
momento em que paramos de perguntar a eles como convertem grama em carneiro assado.

A orquídea, para excitar a abelha, primeiro tem de citá-la. O exemplo é clássico - desde Darwin - mas também um lugar-comum deleuziano: o devir-vespa da orquídea e o devir-orquídea da vespa, não mais imitação, mas captura de código, mais-valia de código, aumento de valência. Seria uma questão de leitura, menos do que de mimese, uma evolução aparalela de dois seres que não têm absolutamente nada a ver um com o outro. Em Staying with the Trouble: Making Kin in the Cthulucene, Donna Haraway comenta uma tirinha intitulada "Bee Orchid", sobre a orquídea Ophrys apifera, uma orquídea que dá o testemunho de uma abelha extinta: the cartoon does something very special; it does not mistake lures for identity; it does not say the flower is exactly like the extinct insect's genitals. Instead, the flower collects up the presence of the bee aslant, in desire and mortality. The shape of the flower is "an idea of what the female bee looked like to the male bee... as interpreted by a plant... the only memory of the bee is a painting by a dying flower." Once embraced by living buzzing bees, the flower is a speaker for the dead. Sobre a aranha, Uexküll diz que ela consegue oferecer, na sua rede, um padrão vazio, eficiente de uma mosca, mas de uma mosca completamente imaginária. Ela utiliza-o, não no interesse da mosca, mas com o fim de a destruir. A teia de aranha funciona como utilizador do significado do objecto significante 'vítima' no mundo-próprio da aranha. Este utilizador de significado é tão rigorosamente adequado ao objecto significante, que nós podemos descrever a teia da aranha como réplica fiel da mosca. Mas alto lá! Não é nada disso o que ela realmente faz. Na verdade, ela constrói a sua teia antes de ter encontrado qualquer mosca; logo a teia não pode ser o retrato de uma mosca real. Ela apresenta, pelo contrário, o desenho de um modelo de 
mosca que não existe em parte nenhuma. ${ }^{44} \mathrm{O}$ modo de citação dos animais também corrobora que não há origem - o devir depende do simulacro, de produção de imagens, de phantasmas; em suma, de imaginação. Sem imaginar não há como dar corpo, pois a experiência de viver em um corpo nunca se delimita pela forma, passando mais bem pelos fluxos - respiração, batimento cardíaco, barulhos, gases, suor, gozo, a água descendo pelo esôfago (stream of bodiness, segundo Ortega y Gasset).

E talvez, porque não vou sozinha ${ }^{45}$, seja possível ir ainda mais longe: a vespa seguramente não devém orquídea da mesma forma em que a orquídea devém vespa. Carla Hustak e Natasha Myers escreveram um texto chamado "Involutionary Momentum: Affective Ecologies and the Sciences of Plant/Insect Encounters". Nesse texto, sugerem - no lugar de teorias evolutivas, em que o que se coloca em primeiro lugar é a competição entre as espécies - a observação dos seres no que diz respeito ao modo como se envolvem; uma espécie de escuta envolutiva (um dos personagens do texto são os Eavesdropping Elms ${ }^{46}$ ) em um mundo onde existem enunciações químicas que convocam outros corpos. Se o fluxo da vida se faz a partir de um conjunto de propostas, há sempre corpos dispostos em registrá-las, em responder da forma como podem e - não menos importante - em não responder. Consider that communication need not to be limited to contexts where individual packets of binary data are both sent and received. Perhaps plant propositions bear no relation to our models of semiosis and syntax. Perhaps they are not "representations" that attempt, successfully or not, to

\footnotetext{
${ }^{44} \mathrm{O}$ trecho continua assim: 'Ora vamos' - já estou ouvindo os mecanistas clamar. - 'Aqui a doutrina dos mundos-próprios denuncia-se como teoria metafísica, pois é metafísico todo aquele que procura os factores actuantes para além do mundo material .'Pois bem. Mas nesse caso, logo depois da teologia, é a física moderna a mais pura das metafísicas. [Os mecanistas da literatura certamente fariam coro!]

${ }^{45}$ Após a morte de Deleuze, Derrida escreve: and I'm going to have to wander all alone in this long conversation that we were supposed to have together.

${ }^{46}$ Isto é, olmos que realizam escutas não-autorizadas, bisbilhoteiras.
} 
name or mirror a preexisting world. In an involutionary reading, signal-response mechanisms give way to livelier ontologies and intra-active worldings. The question becomes, How are affectively charged energies and chemistries transduced within and among bodies? Nesse mundo de proposições, é preciso estar atento - o que há de abelha na lata de coca-cola, o que há de coca-cola na orquídea? Os blocos de devir são da alguma forma semelhantes a enxertos, mas sua virtualidade se reatualiza a cada encontro, não há sutura, não há metamorfose; melhor dizendo, existem passagens entre campos de força que atuam mutuamente, com mais ou menos força, como se dois imãs tivessem sido colocados lado a lado.

Ao que parece, o "como se" parece ser justamente a questão. Uma identidade possível, mas que resvala na própria impossibilidade da identidade. Você se parece, mas - ato contínuo: a vertigem adversativa. Pode ser excesso, mas não seria estranho que fosse uma insuficiência - é quase, mas / can barely put my finger on $i t^{47}$. O que a símile apresenta é a dessemelhança constitutiva da linguagem, o estar fora de si como a condição de qualquer comunicação, de qualquer agenciamento coletivo sensível, ligeiramente deslocado de si ou daquilo que se quer tomar como referência. Como se. Eu como, desde que não tenha que digerir. Ingerir sem digerir é, incidentalmente, uma definição para a origem da vida segundo Lynn Margulis ${ }^{48}$. Bateson, em visita a um zoológico, ao ver dois macacos brincando, foi forçado a rever a noção de que entre os não-humanos não haveria linguagem denotativa. Isso porque os macacos brincavam

\footnotetext{
${ }^{47}$ Expressão em inglês que, dizendo literalmente que não é possível por o dedo sobre algo, expressa a impossibilidade do reconhecimento, da identificação, da determinação. Segundo contam Hustak\&Myers, Darwin com o seu dedo tentava imitar a vespa para observar a ejeção do pólen. Em Manifesto Contrassexual, Paul B. Preciado afirma que às mulheres era interditado justamente o seu próprio dedo em relação ao próprio órgão sexual. O dildo seria então uma prótese não para o pênis, mas para o dedo.

48 A aliança entre bactérias teria dado origem a outros organismos, fenômeno chamado de endosimbiogênese.
} 
como se estivessem em combate: the playful nip denotes the bite, but it does not denote what would be denoted by the bite. Não seria possivel negar, então, a existência de alguma forma de metacomunicação entre os animais ${ }^{49}$. E o que dizer do polvo mimético, Thaumoctopus mimicus, que muda de cor e padrão, inscreve o que está à sua volta em sua pele e, não sendo o que está à sua volta, se anuncia como se fosse? E que além disso finge, brinca de ser, age como se fosse um linguado, uma água-viva, uma cobra do mar, um bicho imaginário? Uma brincadeira séria, em que veste o corpo do outro para se proteger? A iterabilidade, a multiplicação, a repetição inventiva, sem desgaste, só é possível porque é possível existir fora do próprio lugar. Gabriel Tarde: não é à luz que o olho se adapta (nem mesmo que ele corresponde, pois há mil outras maneiras diferentes, além da formação do olho, de corresponder à luz), mas a luz e o olho se adaptam juntos à visão. Emanuele Coccia afirma, em relação às roupas, que o homem é o animal capaz de transformar todas as coisas em sua pelagem: ou melhor, em sua pele. Mas a pele do Thaumoctopus mimicus é ao mesmo tempo tela e projetor. O mundo é a nossa pele. Barthes oferece uma outra versão: a linguagem é uma pele: esfrego minha linguagem contra o outro. É como se tivesse palavras em vez de dedos, ou dedos nas pontas das palavras.

Uma pele que se configura, então, não como fronteira, mas local de indistinção, é o motivo pela qual a enxertia é possível. To write means to graft, diz Derrida. It's the same word..$^{50}$ Jean-Luc Nancy, depois de transplantar o seu coração, diz que seu coração

\footnotetext{
${ }^{49} \mathrm{Em}$ "A Philosphy of Tickling", Aaron Schuster sugere que as cócegas e, mais ainda, o fingir fazer cócegas sem encostar em um bebê stands as the momentous entry-point into the universe of pretense, fiction, and simulation, or to cite the Greek term, mimesis. O autor discute que os primatas também sentiriam cócegas, assim como ratos e a truta.

${ }^{50}$ Derrida diz que grafar significa enxertar, que se trata da mesma palavra. Em português a construção não funciona, mas em francês e em inglês as palavras para "enxertar" são, respectivamente, graffer e to graft, cuja origem etmológico está no grego antigo, graphion, uma variação de grapheion, palavra cujo referente é o estilete, um instrumento para escrever sobre superfícies duras, palavra por sua vez derivada de
} 
agora pode ser o coração de uma mulher negra. O transplante ou o enxerto são antigenealogias. Em seu livro, Uexküll nos relata um experimento de enxertia realizado por Hans Spemann. O tecido de um girino de rã, um animal herbívoro, provido de maxilas e pontas córneas, é enxertado na região oral da larva do tritão, um animal carnívoro, com dentículos. Em um caso, surge na larva do tritão uma boca de girino, com maxilas córneas; em outro, metade da boca se desenvolveu como a de um girino e a outra como a de um tritão. A partir disso, Uexküll sugere que a determinação de significado "boca" se mantém, enquanto que as especificidades - aquilo que ele chama de determinação morfogenética - são modificadas. Essa desobrigação de vínculo idêntico entre sentido e morfogenética seria a comprovação de que, se a máquina se ordena de forma centrípeta, convergindo para uma unidade funcional, o animal se ordena de forma centrífuga, por variação. O mecanismo de uma máquina qualquer, digamos, de um relógio de algibeira, é sempre constituído 'centripetamente', quer dizer, as peças do relógio - os ponteiros, a corda, as rodas - têm de ser aprontadas primeiro, individualmente, antes que sejam ligadas a uma peça central. A estruturação de um animal, pelo contrário, faz-se sempre 'centrifugamente', a partir do germe, que assume primeiro a forma de gástrula e continua depois a adicionar novos esboços de órgãos.

Que as coisas ajam uma sobre as outras, que elas reajam, sugere que a experiência sensível seja a condição do convívio - de viver junto, não a vida comum, mas a vida em comum. Ao redor de nós, com nós, apesar de nós, os encontros configuram um mundo que só pode ser mundo na medida em que devém-sensível. O que poderia existir fora das séries de repetição e diferença, tédio e alegria? Toda a bricolagem genética da qual somos derivados (não como destino final, mas como ponto indefinido

graphein, isto é, escrever. 
em uma série infinita), a bricolagem genética que incubamos em nossos infra-mundos nossos vírus nos fazem fazer rizoma com outros animais (Deleuze e Guattari) -, é fruto de um recorta e cola incansável. Emanuele Coccia: Um mundo em que não houvesse mais cheiros, sons, músicas, um mundo em que as coisas e as formas não fossem mais capazes de viver fora de si para chegar aos viventes, para viver - intencionalmente dentro deles e para influenciar cada movimento seu, seria um mundo privado de consistência unitária. Os meios - enquanto condição de possibilidade de existência do sensível - são o verdadeiro tecido conectivo do mundo. Por meio de redes de fungos, as árvores se comunicam - não apenas os humanos lançam sondas ao desconhecido, senão que todo vivente faz decolar e vê pousar em si emissários telúricos.

Tudo isso começou porque eu queria falar da citação. De como me assombra a citação, algo sobre a citação - o seu fenômeno (a iterabilidade) e também o seu papel neste texto. Mas eu também queria criar uma possibilidade - para falar sobre outros textos, outros tecidos, outros modos de existência. Lo que le gustaba era el fondo del mar, esa otra tierra, llena de planicies que no eran planicies y valles que no eran valles y precipicios que no eran precipicios. Desviar da visão do astronauta, que é a mesma do extraterrestre, que é a mesma de alguns deuses: se há sensível no universo é porque não há nenhum olho observando todas as coisas. Não é um olho que abre o mundo, mas é o sensivel mesmo que abre esse mundo diante dos corpos e dos sujeitos que pensam os corpos. Desde essa perspectiva do substrato terrestre - em que não importa se estamos no fundo do mar, no bosque ou no deserto - que é a condição mesma de toda a subsistência, de toda a vida, pelo menos da vida aqui, da forma como conhecemos, me siento en una roca y me quedo quieto mucho rato, mirándote, convertido yo también en otra roca, y aunque a veces mis ojos pierden de vista 


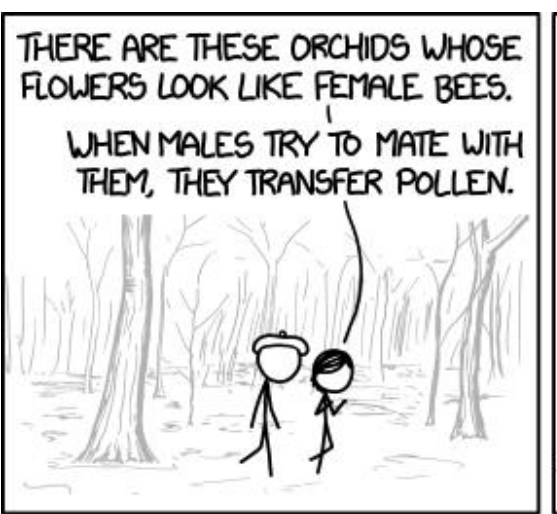

WITHOUT ITS PARTNER, THE ORCHID HAS RESORTED TO SELF-POLLINATING, A LAST-DITCH GENETIC STRATEGY THAT ONLY DELANS THE INEVITABLE.

NOTHING OF THE BEE REMAINS, BUT WE KNOW IT EXISTED FROM THE SHAPE OF THE FLOWER.

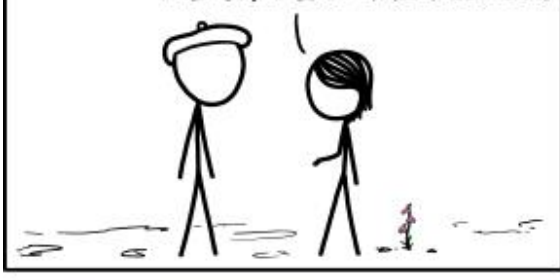

THIS ORCHID - OPHRYS APIFERA-MAKES FLOWERS, BUT NO BEES LAND ONTHEM BECAUSE THE BEE IT MIMICS WENT EXTINCT LONG AGO.

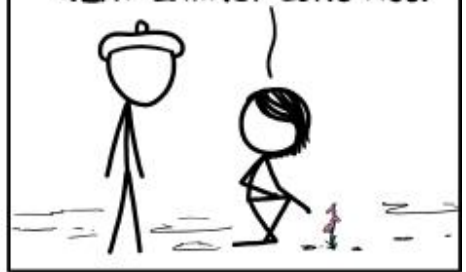

ITS AN IDEA OF WHAT THE FEMALE BEE LOOKED LIKE TO THE MALE BEE...

...AS INTERPRETED BY A PLANT.
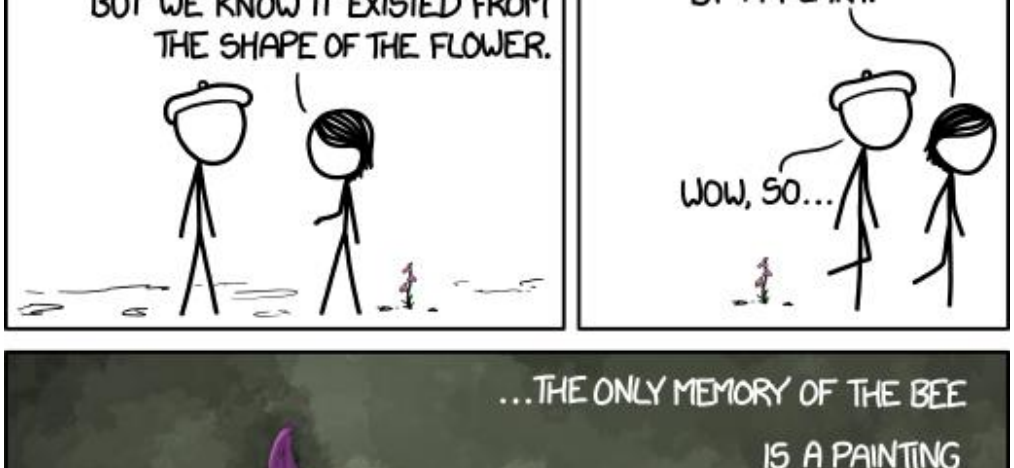

I5 A PAINTING

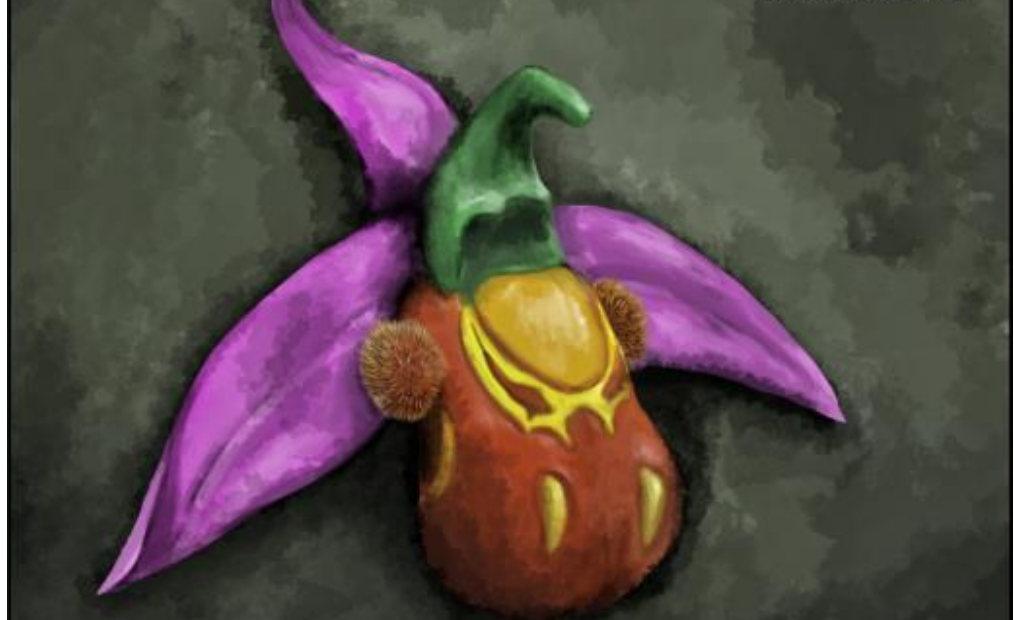

BYA DYING FLOWER.
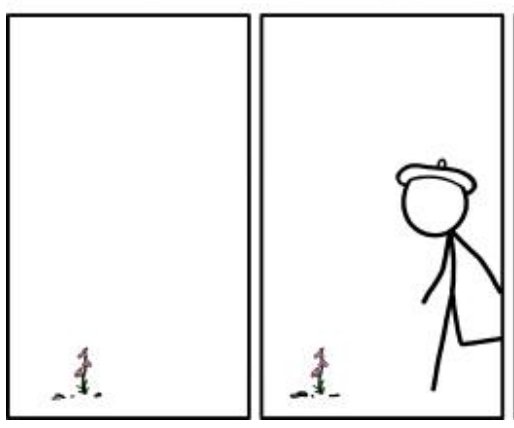

Tradução:

1. Existem orquídeas cujas flores se parecem com abelhas fêmeas. / Quando os machos tentam copular com elas, transferem pólen.

2. Essa orquídea - Ophrys apifera - produz flores, mas nenhuma abelha pousa nelas. / Porque a abelha que ela imita já está extinta há muito tempo.

3. Sem a sua parceira, a orquídea recorreu à autopolinização, uma estratégia genética de último caso que só adia o inevitável. Nada resta daquela abelha, mas a gente sabe que ela existiu por causa do formato da flor.

5. É uma ideia de como a abelha macho percebia a abelha fêmea... / interpretada por uma planta.

- Nossa, então...

6. A única lembrança que se tem da abelha é uma pintura / feita por uma flor moribunda

7. Eu vou me lembrar da sua abelha, orquídea. Eu vou.

Bee Orchid

xkcd.com (Randal Moore) 
Jpost scriptum - para isso continuamos vivas/

À Alexandra Elbakyan, criadora do SciHub

But to learn to live, to learn it from oneself and by oneself, all alone, to teach oneself to live ("I would like to learn to live finally"), is that not impossible for a living being? Is it not what logic itself forbids? To live, by definition, is not something one learns. Not from oneself, it is not learned from life, taught by life.

espías de otro planeta, y también: cuerpos que se desgastan más rápido que otros cuerpos, y también: enfermedades, transmisión de enfermedades, y también: disposición a resistir, y también: ¿dónde se aprende a resistir?, ¿en qué clase de escuela o de universidad?, y también: fábricas, calles desoladas, burdeles, cárceles, y también: la Universidad Desconocida, y también: mientras el Sena fluye y fluye y fluye,

1. Derrida inicia a sua palestra com uma pergunta apropriada: como não falar, hoje, da universidade? A pergunta é dupla, por um lado a inevitabilidade de refletir acerca da universidade, acerca do lugar desde onde se escreve, por exemplo, uma tese, acerca da esquadria, por assim dizer, que emoldura o pensamento universitário; por 
outro, uma precaução sobre as formas em que não se deve falar sobre ela, formas que, desde certa perspectiva, deveriam ser interditadas. Sugerir que a universidade deve abrigar sempre dentro de si a possibilidade do seu fim - a sua possibilidade, e não a sua inevitabilidade -, a consideração de um fim que poderia ser imputada a si mesma, ao mesmo tempo em que se tenta defendê-la do desmonte comissionado pelos piores interesses econômicos e tecnificistas, quase sempre particulares e restritos a um pequeno grupo, é um gesto que tenta reconhecer ambas as perguntas.

2. Falando na Universidade de Cornell, em Ithaca, nos Estados Unidos, uma universidade famosa pelos seus desfiladeiros, pelas suas garagantas, Derrida está interessado em uma questão que passa pela arquitetura e pela topografia. What is the University's view? What are its views? A pergunta, segundo diz, é importante para determinar se há uma razão da universidade, isto é, uma razão de ser da universidade, uma razão como causa, isto é, uma fundação. Uma fundação com vistas a quê? What do we see from the University? Pensar a respeito da universidade significa pensar acerca da topopolítca de um ponto de vista, o ponto de vista da universidade, o ponto de vista desde a universidade ${ }^{51}$. What might the University's diaphragm be? Is the University the

51 E que estranha a topografia da Torre do Relógio da USP, mas também apropriada a certa autonarrativa universitária, um panóptico ao redor do qual se organiza a universidade (uma das justificativas para a criação da Cidade Universitária era o "exercício real e eficiente das funções da Reitoria que assim terá, sob suas vistas imediatas, todo o conjunto universitário"), condicionando ao tempo racionalizado dos ponteiros as suas duas faces, uma representando, segundo explicação no site da Universidade de São Paulo, a fantasia, e a outra a realidade, a face da fantasia tendo como base a filosofia e o seu cume a poesia, a face da realidade apoiando-se na matemática para chegar até a astronomia, como se o zero não fosse apenas um conceito ao qual só é possível acercar-se, como se o céu fosse o mesmo para todos, pois diz-se real aquilo para o qual só há uma versão, como se a astronomia não tivesse sido no princípio uma história, uma filosoficção, não tanto o oposto da poesia como o seu revés, o universo como resultado de suas múltiplas versões, como se o buraco negro não fosse o universo delirando acerca de sua própria inexistência. No chão da praça do relógio, em torno da torre, uma inscrição concebida por Miguel Reale, então reitor da USP, jurista do golpe de 64, notório integralista: "No universo da cultura o centro está em toda parte": a frase, evidentemente, conta com dois sentidos: por um lado a retórica da descentralização e deshierarquização das disciplinas, sejam elas dedicadas à fantasia ou a realidade - já que cabe à cultura principalmente diferenciar e produzir esses dois polos; por outro lado a afirmação perversa de que no universo da cultura não há espaço para aquilo que não 
master of its own diaphragm? What can the University's body see or not see of its own destination, of that in view of which it stands its ground?

3. Derrida está respondendo a outro texto, o "Academic Work: The View from Cornell", de James Siegel, onde é possível ler que Ezra Cornell, o fundador, teve que convencer seus sócios a construir a universidade longe da cidade. Convenceu-os com o argumento razoável de que ali, mais afastada, teria mais espaço para expansão. Derrida diz: a razão venceu - mas também pergunta: estava a razão simplesmente do lado da vida? James Siegel observes (and I quote) that "for Ezra Cornell the association of the view of the university had something to do with death." The question arose once again in 1977, when the university administration proposed to erect protective railings on the Collegetown bridge and the Fall Creek suspension bridge to check thoughts of suicide inspired by the view of the gorge. A preocupação com a vida dos alunos também parecia razoável, mas um membro do corpo docente pronunciou-se contra as barreiras, afirmando que bloquear a vista significaria, nas suas palavras, a destruição da essência da universidade. What did he mean? What is the essence of the university? E qual a sua relação com a morte?

4. A ideia do ensino, a educação como conceito, imagem, proposta e solução, frequentemente está ligada a uma ideia de futuro, de sobrevida, tanto do ponto de vista individual, quanto do ponto de vista mais amplo da escala social: nacional e mundial. São constantes os pedidos por mais e melhor educação, independente dos parâmetros defendidos para o que se considera uma "boa educação". Em seus diversos níveis e

pertence ao centro, para quem não ocupa o panóptico cujo ponto cego é sempre ele mesmo. Tentando pensar de forma otimista, talvez seja por isso que esteja vedado o acesso à torre, pelo menos oficialmente. O comentário irônico, porém, é insuficiente, e em diversas greves encontrou-se a necessidade de tomar a torre - mas bastaria a vista da universidade, desde a universidade? 
modalidades - primário, secundário, superior e técnico -, ela parece estar sempre ligada à ideia de vida, ou de possibilitadora da vida, algo que se idealiza como uma versão do amor 52 , um "dar à luz" que se imiscui também ao "dar a luz", inclusive constando como direito de todos, por lei, na constituição brasileira. É possível pensar em poucas ocasiões em que pareça pertinente falar sobre um "dar a morte", sobre uma forma de levar a óbito que não seja assassinato; em que se torna um imperativo associar direito e morte, um direito à morte, motivo pelo qual são sempre tão difíceis as discussões em torno da eutanásia ou do suicídio. Por isso é tão difícil escrever um texto em que aquilo a que todos supostamente têm direito, a educação, revela o seu necessário interstício entre a vida $e$ a morte. Ainda mais difícil delinear essa relação em um país como o nosso, em que os mecanismos de exclusão, privados e públicos, dos quais a educação também faz parte, sendo também elitista, racista e patriarcal, implicam a morte - tanto o homicídio, quanto o simples deixar morrer - de uma parcela significativa da população, com números superiores a muitos países em guerra. Ninguém, dentro da universidade, ousa falar no seu próprio fim - ainda que seja necessário reconhecer a dificuldade de conjecturar sobre aquilo para o qual não há um depois (mas não seria esta justamente a base de uma pedagogia ética, ensinar o que não se sabe?) -, e considera que as ameaças são sempre externas porque, de fato, lá fora (ou aqui fora) se fala o tempo

52 Não é incomum, diante de campanhas salariais dos professores, que se diga que professor deve trabalhar por amor. (Ou um e-mail como o enviado pela Reitoria da Universidade de São Paulo, em 13 de maio de 2016, que terminava assim: "O resto é maledicência promovida por aqueles que não amam a USP e que não têm compromisso com a pesquisa, com o ensino e com a missão maior da universidade pública"). É evidente que não pode haver condições para ensino sem uma remuneração digna. Por outro lado, é difícil imaginar uma pedagogia sem amor. John D. Caputo situa o trabalho do professor entre a dádiva e a economia: Pedagogy without why does not mean teaching without pay and working for nothing. It applies no less to the students, who will not get by if all they want to do is get by. Here is the first hauntological situation: those of us who spend our lives in the school find ourselves situated between the gift and the economy. We lead haunted lives, charmed or haunted by a call which is too "weak" and spectral to be an imperative even as we must conduct the ordinary business as usual of the economy of the world. 
todo em sua extinção. As greves e as pequenas ou grandes revoltas que marcam a vida universitária nunca querem destruí-la: as barricadas levantadas pelos alunos às vezes querem tanto protegê-la que a resguardam de todos esvaziando os seus prédios e também o seu sentido, que já por norma claudica nos outros dias letivos. Mas também não é verdade que os prédios se veem esvaziar de todos, pois a universidade, mais do que um espaço comum, é um espaço público, isto é, estatal, pelo menos por hora. Recentemente algo mais interessante vem acontecendo, mais interessante porque propõe uma reconfiguração dos limites entre dentro e fora e revela justamente o abismo entre o público e o comum, onde não são os próprios alunos que barricam os próprios prédios, mas aqueles que não têm acesso à universidade - os impróprios -, mais especificamente à Universidade de São Paulo, que há anos arrasta com a barriga a implementação de cotas raciais ${ }^{53}$ e, portanto, de alguma maneira, compactua com o genocídio da juventude negra ao ter parte importante na manutenção das estruturas dos diversos nívies de opressão, cujas intervenções e trancaços se realizam desde fora para reivindicá-la, isto é, inviabilizam o acesso das vias para discutir justamente os mecanismos de acesso. Um aluno estranhou uma vez em sala: por que estamos sempre falando de morte? Talvez porque uma pedagogia que não leve em conta que a questão é sempre de vida e morte acabe por colocar a questão como de vida ou morte, como se a determinação entre uma ou outra fosse a única garantia para o porvir.

\footnotetext{
$53 \quad$ No dia 4 de julho de 2017, a USP aprovou as cotas racias, 15 anos depois da UERJ, a primeira universidade no Brasil a implementá-las (no vestibular de 2002, para ingresso em 2003). As circunstâncias da aprovação, no entanto, confirmam que os setores dominantes da Universidade de São Paulo não tinham a menor intenção de aprová-la: na pauta para votação encontravam-se protocoladas apenas as costas sociais (a proposta para reservas de vagas apresentada pelo Núcleo de Consciência Negra da USP havia sido negada pelo Conselho de Graduação). A pressão realizada por professores e representantes discentes presentes na reunião conquistou a inclusão emergencial da pauta específica das cotas raciais, que foram aprovadas em votação, com 75 votos a favor, oito contrários e nove abstenções.
} 
5. Em "What do children learn at school? - Necropedagogy and the future of the dead child", Ann Pellegrini se interessa pela pergunta postulada por Althusser em Ideologia e aparelhos ideológicos do Estado: o que as crianças aprendem na escola? Se o progresso em direção ao que se chama de pacificação civil necessitou privatizar a religião e estabelecer no âmbito público a razão secular para fundar o estado-nação moderno, isso também quer dizer que a escola passa a ocupar o lugar da igreja em muitos sentidos, como lugar de condução moral, direcionando a população à salvação, embora a uma salvação de caráter não-transcendente. Dentro do universo argumentativo de Althusser, a criança-que-sabe, isto é, a criança a que se ensina, é o ponto nodal entre a produção de um indivíduo concreto condicionado a um sujeito concreto e a reprodução das relações sociais dominantes - a reprodução das condições de produção. ${ }^{54}$ Pellegrini escolhe focalizar uma iniciativa educacional por parte do presidente francês Nicolas Sarkozy, anunciada em 2008. No outono daquele ano, a cada aluno francês da quinta série seria designada a história de vida de uma criança francesa vítima do Holocausto. A ideia era uma investigação da alteridade que passasse (estranhamente) pela superação da diferença: as crianças, vivas, vendo que as crianças mortas tinham, segundo Sarkozy, as mesmas brincadeiras, as mesmas alegrias e as mesmas esperanças se identificariam com aqueles que no início dos 40 tiveram o azar

54 O conceito de criança, diz Pellegrini, foi criado em simultaneidade com o conceito de religião e o conceito de secular; a determinação de uma progressão exemplar da criança à maturidade adulta está diretamente ligada à situação de outras culturas e naturezas a uma temporalidade infante, como se elas fossem um testemunho do passado inocente e subdesenvolvido do ocidente. Esses outros são considerados infantis em proporção àquilo que se considera uma infância inapropriada: quanto mais a criança do outro assume tarefas e conhecimentos que são considerados inadequados à infância de suas próprias crianças, mais infantil se tornam enquanto uma sociedade inteira. A criança e uma infância que produza essa criança-conceito passam a atuar como um indicador social para a civilidade e o progresso: o cristianismo segue nas entrelinhas daquilo que seria a base do secularismo na medida em que seus ideais de vida sem pecado, ênfase na família e um ordenamento temporal certeiro, construído por etapas a serem superadas, seguem pautando, por exemplo, discussões globalizadas de trabalho infantil e o tráfico sexual de mulheres e crianças. 
de serem definidos como judeus. A máxima cristã: amai o outro como a ti mesmo. Ou a definição de Antonio Candido, em "O direito à literatura", sobre o que seriam os direitos humanos: reconhecer que aquilo que consideramos indispensável para nós é também indispensável para o próximo. Territórios delicados para adentrar munido de um espelho. A ênfase estava naquilo que os tornava iguais, portanto, às crianças mortas, apesar do "azar" (nenhuma menção aos criminosos e aos colaboradores) de as crianças judias terem sido definidas em função de sua diferença (Pellegrini pergunta: diferença em relação a quê? a uma essência francesa? ao humano universal? à essência francesa como o humano universal?). Depois de protestos, sob a justificativa de que o peso emocional de um aluno carregar sozinho o fardo da história de uma criança morta seria excessivo, a iniciativa passou a designar uma criança morta a cada turma de uma sala.

6. Alguns anos antes, em 2004, uma reforma educacional havia banido o uso de adereços e vestimentas religiosas ostensivas (embora a palavra francesa tenues pode indicar algo que vai além das roupas e adereços). O qualificador que designa ostentação, um critério de visibilidade, definitivamente conduzia a constituição do espaço laico em direção às discretas correntinhas com crucifixo sob a camisa em detrimento dos véus islâmicos. O secularismo cristão às vezes concede ao judaísmo a possibilidade de um hífen e, em nome do pensamento judaico-cristão, na origem de todo o pensamento ocidental, em nome da laicidade, dirigem-se ao islâmicos, eles sim violentos. O que a criança aprende na escola? Definitivamente a pergunta é complexa: qual criança e qual ideia de criança? Ao imaginar-se no lugar do morto, a criança é forçada a sedimentar bem as semelhanças daquilo que constitui a criança universal francesa, tendo o seu foco desviado daquilo que tornava aquela criança diferente e, por isso mesmo, passiva de ser morta. O que essa criança francesa aprende e reafirma, portanto, é a sua universalidade 
destinada à sobrevivência, ensinando não a morte, mas a ressurreição. Living French children are called to identify with dead Jewish child-victims. This identification produces a third child - let's call it the "virtual" child, the child yet-to-be. This virtual child figures a future in which difference has been left behind. There is something disturbingly Hegelian in this overcoming of the dead child on the way to becoming a modern subject of/in history. (...) A fresh and no-less-ferocious irony, then, appears at the prospect of French Muslim children being asked to identify with dead Jewish ones in order NOT to become "the Muslims" they are already imagined to be. A relação entre pedagogia e necrofilia leva justamente ao ponto de encontro entre a biopolítica e a necropolítica. Se não é possível conceber a política sem uma ideia de futuro, a criança passa a assegurar para todos justamente a fantasia do futuro. A biopolítica implica a necropolítica porque considera-se que nem todas as vidas devem ser reproduzidas: qual criança deve ser produzida para que reproduza - qual criança, qual futuro? A fantasia do futuro tem consequências na medida em que essa criança virtual se atualiza no presente, e conforma e regula a vida sexual e a reprodução, associando-as à transmissão pedagógica do conhecimento.

7. Derrida, ainda lá em Ithaca, conta ao auditório que um professor havia escrito recentemente que a certain theoretical movement - a desconstrução - was mostly supported, within the university, by homosexuals and feminists, e depois complementa: a fact which seemed very significant to him (o professor), and doubtless a sign of asexuality. Momentos antes, Derrida havia citado Schelling acerca do sexo das abelhas para demonstrar a correlação frequente que se faz de um naturalismo, organicismo, ou vitalismo com a unidade do conhecimento, isto é, tomar a base da universidade como um sistema orgânico social. Schelling, em um grande momento necropedagógico, via 
Derrida: Any thought which has not been formed in this spirit of unity and totality is empty in itself, and must be challenged; whatever is incapable of fitting harmoniously within that budding, living totality is a dead shoot which sooner or later will be eliminated by organic laws; doubtless there also exist, whithin the realm of science, numerous sexless bees who, since they have not been granted the capacity to create, multiply in inorganic shoots the outward signs of their own witlessness. Os ineptos para reproduzir, pelo menos desde uma perspectiva biológica, e, ainda mais particular, dentro de uma perspectiva sexuada, então, convertem-se em brotos inorgânicos, mortos, sem futuro, eliminados pelas leis naturais. E se não têm a capacidade de criar, podem, no entanto, multiplicar e tornar visíveis a extrusão de sua desrazão, produzindo nada mais que a própria marca de inadequação. O pressuposto do organismo social, segundo Schelling, é de que só pode estar do lado da razão quem está disposto a reproduzi-lo em seu funcionamento total, em que a única relação possível de ser estabelecida é metonímica. Mas mais do que leis naturais, o que está em jogo são as leis naturalizadas; Jean-Luc Nancy diz, em "Sexistance", que a reprodução assexuada, sucedendo combinatoriamente por meio de mutações, não está menos apta à diversificação, muito pelo contrário, pois tem a vantagem da velocidade. A reprodução sexuada está muito mais ligada à preservação do que à diversficação ${ }^{55}$. O que pensaria Schelling da clonagem, a reprodução metonímica mais perfeita, que além de assexuada, é também mediada por nós, não pelo nosso corpo - como fazemos o tempo todo com

55 Paul B. Preciado afirma que a contrassexualidade encontra como forma de resistência justamente a contraprodutividade, isto é, a produção de formas de prazer-saber alternativas à sexualidade moderna. Na última parte de seu Manifesto Contrassexual, entitulado "Da filosofia como modo superior de dar o cu", Preciado lê Deleuze lendo Proust, além de "Carta a um crítico severo", para dizer que a homossexualidade impulsiona uma paradoxal "fecundação estéril" e, voltando aos insetos polinizadores (às abelhas e vespas), sugere que o que estes seres alados possibilitam é o estabelecimento de conexões fecundantes entre hermafroditas. 
os vírus - mas pela própria razão? Retornando à ficção da criança universal e do conhecimento universal - e à necropedagogia que opera a passagem entre um e o outro -, o que se quer assegurar é a reprodução das relações de viver e morrer (Lee Edelman chamou isso de reproductive futurism ${ }^{56}$ ). Para que somente o mesmo possa sobreviver, quem deve morrer é sempre o outro e essa morte por sua vez deve ser superada por meio da perpetuação daqueles mesmos jogos, daquelas mesmas alegrias, daquelas mesmas esperanças, nas quais a educação se torna o lastro de um projeto de futuro universal, não porque disponível a todos, mas porque deve ser almejado por todos alguns, sempre os mesmos outros, devem até sacrificar-se por ele. A pedagogia como uma questão de vida ou morte, portanto.

8. Mas se a questão é de vida e morte, isto é, se a questão da razão de ser da universidade tiver que passar pela morte, a questão ainda pode ser de como morrer. E como também se trata de uma questão de vida, é preciso também defendê-la - e a questão novamente é de como defendê-la. Derrida perguntou: como não falar da universidade hoje? Apontar para a sua monstruosidade burocrática apoiada sobre carimbos, como uma espécie de cybertumor auto-imune que não para de reproduzir-se a si mesma - papers infinitos interconectados com outros pelas velozes transmissões de fibra ótica em bases de dados indexadas em índices de avaliação - ; enfatizar a sua ineficácia, o seu caminhar zumbi, o tédio dos alunos, o tédio dos professores, todos esses fatores constam também no coro de quem quer otimizá-la, privatizá-la, contratar

56 Segundo Lee Edelman, em No Future, há uma universalização coercitiva da imagem da criança, uma imagem que não deve ser confundida com as experências vividas de nenhuma criança histórica, cuja projeção como meta pressupõe a heteronormatividade (a despeito das inúmeras possibilidades que casais homoafetivos encontram hoje para serem pais e mães e a despeito do fato de que casais heterossexuais fazem sexo o tempo todo sem fins reprodutivos), de modo que o culto adulto à criança não se estende à criança queer, que neste cenário só pode representar o fim da criança e da infância. Não à toa, se comparados a outros grupos, os jovens LGBTTQ apresentam índices de suicídio elevados. No baby, no future, resume Edelman. 
professores com mais três outros empregos, enxugar o quadro de funcionários, veremse livres dos cursos sem utilidade técnica. Parece que, desde as mais diversas perspectivas, não há quem defenda a universidade exatamente da forma como ela existe hoje, especificamente em sua conformação atual. Nos sentiríamos melhor na universidade se não fossem essas também as questões, se não fossem essas as questões, nos sentiríamos melhor se pensássemos que a sua crise levaria a alguma revelação, but we feel bad, diz Derrida em outra ocasião, who would dare to say otherwise? And those who feel good are perhaps hiding something, from others or from themselves. Como defendê-la sem enfatizar a sua excepcionalidade, a sua alta-cultura, a importância de sua tradição, os seus feitos inigualáveis? Como defendê-la sem apelar à universalidade de seu poder retórico, justificar a sua existência em benefício do estado, como provedora do humanismo, a universidade como o braço humanizador do estado, ainda mais quando o estado já prescinde de sua mediação entre soberania e população? Tentar refundar a universidade, isto é, autorizar-se sobre a sua própria fundação quando ela, a fundação, já não está mais lá, talvez nunca tenha estado exatamente lá, impede qualquer diálogo, pois transforma-se em um diálogo sem referente, aprofunda a crise, e é em nome da gestão da crise - método de pura administração por meio da desqualificação sumária de qualquer voz dissonante, quando não a violência, a tropa de choque, o corte de pontos dos funcionários -, que o seu desmonte vai sendo levado a cabo.

9. Willy Thayer, em A crise não moderna da universidade moderna, escreve que há uma despotencialização da alegria perante a crise porque stricto sensu, a crise já não constituiria um signo de progresso. Contexto que define, então, o fim da crise como crise de progresso. É como se a universidade dissesse que a sua auto-narrativa já previu tudo, 
57 Em $O$ conflito das Faculdades, texto fundacional sobre os propósitos e os limites da universidade moderna, Kant inicia o seu texto com uma troca de cartas entre ele e o rei da Prússia, Frederico Guilherme II. Kant é acusado, pelo rei, de fazer um mau uso da vossa filosofia para deformar e degradar as doutrinas capitais e fundamentais da Sagrada Escritura e do cristianismo; que fizestes isso sobretudo no vosso livro A Religião nos Limites da simples Razão, bem como noutros tratados mais pequenos. Esperávamos mais e melhor da Vossa parte; pois Vós mesmo deveis reconhecer de que modo irresponsável agis assim contra o vosso dever, enquanto mestre da juventude, e contra as nossas intenções soberanas, que Vos são muito conhecidas. Kant responde bastante enfaticamente afirmando que, entre outros pontos, como educador do povo, em escritos, sobretudo no livro A religião nos Limites, etc., nunca fui contra as intenções supremas e soberanas, de mim muito conhecidas, i.e., não causei dano à religião pública do país; o que é já evidente em virtude de esse livro não ser para tal apropriado, é antes um livro ininteligivel e ocluso para o público e representa tão-só um litígio entre eruditos da Faculdade, acerca do qual o povo nada sabe; mas, a este respeito, as próprias Faculdades permanecem livres para proferir um juizo público, segundo o seu melhor saber e consciência; e que só os mestres populares constituídos (nas escolas e nos púlpitos) estão vinculados ao resultado das discussões que a autoridade do país sanciona em vista da exposição pública. A partir disso é possível depreender a) que somente acadêmicos podem julgar outros acadêmicos; b) que a essa autonomia é interditada a produção dos efeitos públicos dessa autonomia - Derrida: The autonomy of scientific evaluation may be absolute and unconditioned, but the political effects of its legitimation, even supposing that one could in all rigor distinguish them, are no less controlled, measured, and overseen by a power outside the university; c) que aquilo que se compreende como público é instável no tocante à sua relação com o povo. Embora não tenhamos o luxo de ter um rei censor - um interlocutor definido -, visto que a censura hoje se esgueira mais sorrateiramente de acordo com decisões administrativas referentes ao financiamento, pode valer a pena deter-se sobre a forma constitutiva daquilo que chamamos, e frequentemente defendemos, como autonomia universitária. Kant defende em seu texto fundacional o conflito das faculdades como premissa constitutiva da universidade, pois está preocupado em criar um sistema que garanta indefinidamente o compromisso com a razão, a verdade e a ciência. Da forma como ele pensa, existem as faculdades superiores (Teologia, Medicina, Direito) e a faculdade inferior (Filosofia); o conflito entre elas é necessário, pois caberia à Faculdade de Filosofia, em seu compromisso com a verdade, a fiscalização das faculdades superiores que, segundo ele, seriam mais facilmente cooptadas pelo governo ou porque querem, de fato, o governo. Kant sugere, inclusive, que o governo seria também objeto de escrutínio teórico da Faculdade de Filosofia, já que razão e governo devem ser, para ele, coextensivos. A ideia, no entanto, não pode ser a de desestabilizar o governo, já que o governo é quem garantiria por lei a liberdade da Faculdade de Filosofia e, dentro desse quadro, Kant delineia o que ele chama de conflito legal e ilegal das faculdades. 0 poder da universidade estaria em poder resistir ao abuso de poder; no entanto, esse poder está limitado ao poder de pensar e julgar, um poder de dizer, mas não dizer publicamente, fora da universidade, pois dizer algo publicamente, sem o aval do governo, implicaria uma tomada de posição ou fomentaria uma tomada de ação, um poder de execução que estaria negado à universidade, segundo Kant, justamente para impedir a tomada de poder ou o risco de ser tomada pelo poder. $\mathrm{O}$ conflito legal e legítimo, portanto, seria a autonomia no que concerne aos eruditos emitirem pareceres sobre outros eruditos. 0 conflito ilegal, no entanto, estaria na publicização de fato dos discursos eruditos, segundo nos diz em nota: se o conflito fosse apresentado à comunidade civil (publicamente, por exemplo, nos púlpitos), como de bom grado tentam os profissionais (sob o nome de práticos), seria de modo incompetente submetido ao tribunal do povo (ao qual não cabe juízo algum em matérias de ciência) e deixa de ser um conflito de eruditos; e surge então o estado de conflito ilegal, que acima se mencionou, em que se expõem doutrinas conformes às tendências populares e se espalha a semente da insurreição e das facções, pondo assim o governo em perigo. (...) Em contrapartida, merecem ser marcados com tal ferrete os que introduzem uma forma inteiramente 
de contrato social que agora não tem mais vigência. Essa ruptura, causada por aquilo que ele chama de equivalência neoliberal, ou seja, aquilo que reduz toda a produção universitária a uma intercambiabilidade geral mercadológica, aumentando a acumulação da crítica universitária, mas sem a crítica da acumulação, dá sequência a uma perda de especificidade da universidade, que vai vendo as suas fronteiras se dissolverem entre Institutos Técnicos e Tecnológicos (sejam eles públicos ou privados), faculdades particulares pouco voltadas à pesquisa, e também à world wide web, que se assemelha muito à universidade no que diz respeito à sua constituição arquivológica e à sua pretensa ausência de fronteiras. Isso porque, ainda segundo Villalobos-Ruminott, a constituição do poder já não passa pela mediação humanista-letrada. La postuniversidad es ya la universidad, no en su diversidad fenoménica, sino en su inscripción en la nueva división internacional del trabajo, donde más que informar el pacto social, lo confirma ex-postfactum, mediante la producción de consensos compensatorios ya sancionados fácticamente por los poderes de turno. Em vez de uma universalidade que busque a des-historização de uma origem como verdade, há uma marcha superhistorizada que progride em função de uma meta. Esse deslocamento da universidade agora destituída de sua vocação como local de legitimação (a hipótese é de que o estado já não precisa legitimar-se, pois reproduz em si mesmo o seu próprio poder) faz com que a politicidade moderna perca a sua potencialidade pretendida: mientras más afirmamos esta politicidad, más lejos parecemos ubicarnos desde la posibilidad de hiperpolitizar la cuestión del nuevo contrato social universitario, abasteciendo la misma economía nómico-identitaria que estructuró a la universidad moderna. Villalobos-

diversa de governo, ou antes, uma ausência de governo (anarquia), abandonando à decisão da voz do povo o que é um assunto da ciência e, dirigindo à descrição o seu juízo por meio da influência nos seus hábitos, sentimentos e tendências, podem deste modo tirar o influxo de um governo legítimo. 
Ruminott sugere em seu texto que la lucha por la hegemonía como estrategia contra la indiferenciación equivalencial capitalista termina entonces, a pesar de las pulsiones prácticas y las formas del activismo y las formas del activismo comprometido, en una confirmación de la misma equivalencialidad, predomino de valor cambiario y reterritorialización nómica de la imaginación. A imaginação parece estar no centro da disputa como uma forma de visão que não requer olhos abertos - Derrida, ainda falando lá em Cornell, diz que é por isso que a universidade não pode ser um animal de olhos duros $^{58}$.

10. Como morrer e como defender, portanto. Às vezes é preciso saber fechar os olhos. Derrida (será que falava sentado ou em pé?): Beware of what opens the university to the outside and the bottomless, but also of what, closing it in on itself, would create only an illusion of closure, would make the university available to any sort of interest, or else render it perfectly useless. Beware of ends; but what would a university be without ends? O que a universidade seria sem um fim? E estaria o seu fim, o seu declínio, atrelado à sua razão de ser, à sua finalidade? Ou estaria o fim decretado pela sua impossibilidade de cumprir a sua finalidade? Estamos sempre retornando ao fim, chegando de novo ao fim. Qual a razão de ser da universidade? Derrida diz que até onde ele sabe, nunca se fundou uma universidade contra a razão, o que permite a suposição razoável de que a razão de ser da universidade sempre foi a razão, ou alguma relação essencial entre razão e ser. Derrida lembra a plateia que segundo o princípio da razão de Leibniz "de toda verdade se pode dar a razão" (latim reddere rationem, francês rendre raison), ou seja, que o princípio da razão deve ser dado, isto é, a verdade só existe na

58 Segundo Aristóteles, em A parte dos Animais, os animais sem pálpebras, "à falta desta protecção, (...) têm os olhos duros, como se pudessem ver através de uma pálpebra aderente ao olho". 
medida em que a razão pode ser dada a ela. Ele se pergunta: o que quer dizer aqui "dar"? E se o verbo em questão é "dar", daria a razão lugar à troca, circulação, empréstimo, dívida, doação, restituição? E quem seria então responsável por essa dívida ou por esse dever, e perante quem? Se a questão é a responsabilidade, continua Derrida, is answering to the principle of reason the same act as answering for the principle of reason? Is the scene the same? Is the landscape the same? And where is the university located within this space? A possibilidade da universidade moderna, aquela que se reestrutura no século XIX, é impensável sem interrogar esse acontecimento ou essa instituição do princípio de razão. Responder ao apelo do princípio de razão é dar a razão, explicar racionalmente os efeitos pelas causas. Mas responder pelo princípio de razão, e, portanto, pela universidade, responder por esse apelo, interrogar-se a respeito da origem ou do fundamento desse princípio do fundamento, não é simplesmente obedecer a ele ou responder perante ele. We do not listen in the same way when we are responding to a summons as when we are questioning its meaning, its origin, its possibility, its goal, its limits. Are we obeying the principle of reason when we ask what grounds this principle which is itself a principle of grounding? We are not - which does not mean that we are disobeying it, either. Are we dealing here with a circle or with an abyss? Perseguir o círculo seria medir a razão com a razão, seria dar razão ao princípio da razão, pedir ao princípio que explique algo sobre si mesmo exatamente ali onde ele é cego: a razão da razão não é racional. O abismo, a garganta, seria, segundo Derrida, a impossibilidade para um princípio de fundação fundar-se a si mesmo. This very grounding, then, like the university, would have to hold itself suspended above a most peculiar void. O que significaria defender a universidade olhando não para ela, mas para o seu desfiladeiro? Derrida pergunta: who is more faithful to reason's call, who hears it 
with a keener ear, who better sees the difference, the one who offers questions in return and tries to think through the possibility of that summons, or the one who does not want to hear any question about the reason of reason? A linha teórica a que se convencionou chamar de desconstrução tem sido acusada frequentemente de resultar em paralisia, em algo parecido ao niilismo e à eutanásia da razão; a assexualidade, além de não ser nem de longe a norma para feministas e homossexuais, quando associada a uma abdicação dos circuitos racionais da preservação, é mais uma versão dessa formulação. De qualquer modo, também são feministas e homossexuais que criticam a desconstrução pela sua catatonia. Falando sobre sonhar com o inumerável, para além do "dois" da diferença sexual, John D. Caputo, em um texto sobre Derrida e feminismo, retoma the view from Cornell, mas dessa vez Cornell é uma mulher, Drucilla Cornell, professora de teoria legal feminista, que, ao contrário do que afirmam seus colegas, defende que a desconstrução não obstrui a possibilidade de justiça ao evidenciar a indecidibilidade como o motor de uma atopia ética. A vista de Drucilla Cornell é também para o abismo, mas os seus olhos piscam, um tipo de iluminação não iluminista que conta com o movimento das pálpebras para buscar, na sua intermitência, an opening, a little crack or crevice in the system, through which, segundo Caputo, the fragile shoots (de novo os brotos) of freedom, novelty, and difference can make their way. Claro, porque a questão nunca é decidir de uma vez por todas, pela última vez, entre o abismo e o círculo, mas aprender a viver com a ameaça constante que o indecidível impõe, aprender a operar dentro de suas linhas de força. To stay with the trouble, permanecer com o problema, como diz Donna Haraway sobre o fim do mundo. Olhando desde a vista de Cornell, as a "science" of the "threshold", deconstruction dares us to commit to a 
"cross over" and perhaps, by doing so, to avoid the horror of having the door of the Law of Law finally shut in our faces.

11. O que poderia existir no lugar da universidade? Não exatamente em vez de a universidade, mas em seu lugar? Que tipo de comunidade poderia se formar em torno do pensamento acerca do princípio da razão, uma comunidade que questionasse a instituição naquilo que se ergue sobre o princípio da razão, mas também sobre aquilo que se mantém escondido nesse princípio, não para revelá-lo, pois aí estaria o fim de todos os fins, o gesto mais impossível, escrever e pensar desde o abismo (e penso aqui na carta terrível e doce de Torquato Neto, com um refrão em caixa alta (...)FICO(...) FICO(...)FICO(...), uma palavra pertubadora pescada no oceano das palavras, uma escolha peculiar para quem comunica um último gesto), mas para visitá-lo, escrever e pensar com esse abismo, afeiçoar-se à sua co-presença? It would be the responsibility of a community of thought ${ }^{59}$ for which the frontier beween basic and oriented research would no longer be secured, or in any event not under the same conditions as before. I call it a community of thought in the broad sense - "at large" - rather than a community

59 A palavra "comunidade" causa estranhamento em Derrida; apesar de grandes interlocutores seus, como Jean-Luc Nancy e Maurice Blanchot terem se debruçado sobre o tema da comunidade para além da comunhão transcendental ou do comunismo estatal, Derrida raramente utilizou a palavra. Em seus cadernos pessoais, em uma anotação de um sonho, ele chega a falar em "asco": Dream. Taking part in a national political meeting. I start to speak. Accuse everyone. (As usual: I never form alliances and shoot in every direction: completely alone. Fear is an alliance, and that sense of security that maintains the alliance. I'm really afraid of this, which means there is nothing heroic about my solitude - instead, something fearful and cowardly: 'they can't catch me here' - and I start to seek the cause in flight from alliance and disgust with 'community'. This very word makes me sick.). Em uma entrevista, publicada como "A 'Madness' Must Watch Over Thinking", explica suas ressalvas: of readers.

Q.: You urge two things: to displace the practices of reading and to create a sort of community

J.D.: I don't much like the word community, I am not even sure I like the thing.

Q.: You were the one who used it.

J. D.: If by community one imples, as is often the case, a harmonious group, consensus, and fundamental agreement beneath the phenomena of discord or war, then I don't believe in it very much and I sense in as much threat as a promise. 
of research, of science or philosophy, since these values are most often subjected to the unquestioned authority of a principle of reason. A razão é apenas uma das formas do pensamento - o que não quer dizer que as outras formas são exatamente "irracionais" - e a universidadade apenas um dos seus lugares possíveis. E não se trataria, diz Derrida, meramente de postular questões ao mesmo tempo em que se submete a si mesmo ao princípio da razão, mas também de transformar os modos de escrita, as abordagens pedagógicas, os procedimentos de troca acadêmica, a relação com a linguagem, com outras disciplinas, com a instituição em geral, ao seu dentro e ao seu fora ${ }^{60}$. There is $a$ double gesture here, a double postulation: to ensure professional competence and the most serious tradition of the university even while going as far as possible, theoretically and practically, in the most directly underground thinking about the abyss beneath the university, to think at one and the same time the entire "Cornellian" landscape - the campus on the heights, the bridges, and if necessary the barriers above the abyss - and the abyss itself. Um pensamento subterrâneo que possibilitasse uma forma de administração que não produzisse uma instituição administrada, uma preocupação por programas que não programassem a instituição. É comum criticarmos a universidade por seus cursos com viés profissionalizante, aqueles que, dizemos, dirigem os alunos unicamente ao mercado de trabalho, mas pouco se fala dos processos na universidade que garantem, muitas vezes em condições igualmente perversas, a reprodução de sua

60 Olhando desde onde, porém, seria possível fazer essas perguntas? Isso talvez porque seja difícil de imaginar um modo não-universitário de falar da universidade. É ela que parece criar as categorias a partir da qual ela pode ser indagada, já que a investigação sobre sua razão de ser pressupõe o seu aval e respaldo, como se coubesse sempre a ela a metacrítica final; como se não fosse possível falar a respeito dela já que estaria ela sempre falando por meio de nós. Sobre uma linguagem que desse conta de falar da universidade sem reinstaurá-la como instituição no ato da fala, Willy Thayer tem algumas perguntas: Como, em que idioma não falar contextualmente do contexto? Como, em que idioma não falar categorialmente das categorias universitárias? Como, em que língua, ler a língua universitária? Como, em que idioma não falar a língua universitária e ser escutado por ela? Como não falar, por último, e ser ouvido? E como fazer-se ouvir sem deixar-se assimilar, sequer por ele mesmo? 
própria competência profissional, preparando seus futuros professores para uma pedagogia (em que a sala de aula nunca é uma questão) e para um modo de pesquisa que respeitam certos códigos, performados em um gênero imutável (o texto acadêmico como o único gênero autoevidente, isento de questionamento e transformação, a forma perfeita da expressão). Derrida, no começo da sua palestra, fala sobre ser um "ubiquista", in French, an ubiquiste is someone who travels a lot and travels fast, giving the illusion of being everywhere at once. He is unaware of the context, the proper rituals, and the changed environment, não adere aos rituais de sofrimento embora não deixe de sofrer. Essa comunidade pensante, essa comunidade escrevente, é a abertura para um evento sobre o qual não é possível saber ao certo se, mesmo apresentando-se desde a universidade, pode pertencer à história da universidade - um texto que sabe que é exatamente nesse ponto que se avizinha ao suicídio. Entre o abismo e a universidade, entre o abismo que constitui a universidade e a universidade suspensa sobre a sua própria cegueira a escolha é sempre difícil, we are in an implacable political topography: one step further in view of greater profundity or radicalization, even going beyond the "profound" and the "radical", the principal, the arkhe, one step further toward a sort of original an-archy risks producing or reproducing the hierarchy. "Thought" requires both the principle of reason and what is beyond the principle of reason, the arkhe and anarchy. Between the two, the difference of a breath or an accent, only the enactment of this "thought" can decide. That decision is always risky, it always risks the worst. To claim to eliminate that risk by an institutional program is quite simply to erect a barricade against a future. The decision of thought cannot be an intra-institutional event, an academic moment. $\mathrm{O}$ apelo que vem do abismo ata em um mesmo instante o desejo pela memória - afinal, há algo na universidade que não queremos deixar morrer - e uma 
exposição ao futuro, um outro futuro, que não passe pela necropolítica, que não passe pelas mesmas alegrias, as mesmas esperanças, as mesmas brincadeiras, que resista à biopolítica, porque incerto de seu evento, um futuro com o qual não é possível estabelecer nem uma relação de pertencimento nem de previsão. Uma comunidade que, preocupada com um ritmo dissonante, deslocada (o que de maneira alguma deveria querer dizer afastada) das constrições temporais dominantes, reflete sobre as condições da reflexão, as if with the help of a new optical device one could finally see sight, could not only view the natural landscape, the city, the bridge and the abyss, but could view viewing. As if through an acoustical device one could hear hearing, in other words, seize the inaudible in a sort of poetic telephony. Não é possível dizer, diz Derrida, que tal forma de pensamento possa reunir uma comunidade ou fundar uma instituição no sentido tradicional dessas palavras - o que comunidade e instituição querem dizer, juntas, separadas, ou em oposição, também deve passar, então, pelo teste do abismo.

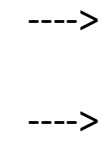

A essa altura, nas minhas notas para a escrita deste texto há uma seta que diz: reencontrar o fio do suicídio. - hesitar durante uma ideia. Aqui, algum tempo depois, assombrada por minha caligrafia torta, por esse comando inusual que me devolve a esse lugar instável, penso que eu quis escrever hesitar diante de uma ideia. Mas o que acabei dizendo é que considerar o suicídio é ao mesmo tempo abismo e o círculo, não apenas o hesitar à beira do abismo, mas hesitar sobrevoando-o com algo que antecede a vista, hesitar o tempo todo durante o sobrevoo de uma ideia. Entre a carta de amor e a carta de despedida. Esse post scriptum já teve outro nome, se chamava "Essa estranha 
instituição (the university, what an idea!)", falava sobre o suicídio de Aaron Swartz ${ }^{61}$ e começava assim: Para a lousa é muito difícil competir com a janela. Iggy Pop: I'm bored/I'm bored/I'm the chairman of the bored. O que estou fazendo aqui? Heidegger escreveu bastante sobre o tédio, dizia que in becoming bored by something we are precisely still held fast by that which is boring, we do not yet let it go, or we are compelled by it, bound to it for whatever reason. Para Benjamin, o tédio é o ponto mais alto da distensão psíquica. O tédio é o pássaro que choca os ovos da experiência. O texto que antes exisitia no lugar deste terminava com uma professora perseguindo, com os seus alunos, um vaga-lume pela sala. E foi mesmo em uma aula em que estavam suspensos os roteiros da tragédia e da farsa que descobri que a janela a que me referia era, na verdade, talvez, à janela de Ana C.; Ela ficava olhando pela janela / vertendo seu único olho pela janela / com o pé em cima da janela / Ela ficava olhando pela janela / O dia inteiro o olho, o pé, a janela / em cima embaixo pelos lados da janela / Ela ficava olhando pela janela / um dia ela cansou de olhar e fechou a janela / mas era dura e não fechava a janela / Ela ficava olhando pela janela / às vezes tentava mas logo esquecia da janela / que sempre aberta com um olho e um pé a janela / Ela ficava olhando pela janela / até que um dia seus pensamentos dissociaram a janela / que caiu inteiriça, e era uma caída janela / Ela ficava olhando pela janela / que não era, nem existia como janela: / Ela ficava olhando pelo buraco, eu também amblíope. Deleuze, que também teve o seu encontro com a janela, diz: Para mim, duas coisas são importantes: a relação que

\footnotetext{
${ }^{61}$ Aaron Swartz se enforcou com um cinto em seu apartamento em janeiro de $2013-$ tinha 26 anos. Sofria há dois anos um processo movido contra ele pelo governo federal acusado de crime de invasão de computadores, correndo o risco de, se considerado culpado diante de um júri popular, ser condenado a até 35 anos de prisão. Em 2011 ele havia utilizado a rede do MIT para baixar mais de quatro milhões de artigos do JSTOR com o objetivo de disponibilizá-los publicamente. O MIT, acusado de cooperar com o governo na persecução de Swartz, produziu um relatório de apuração interno à universidade, tornado público, junto com uma série de outros documentos pertinentes ao caso, por meio do site: http://swartzreport.mit.edu/
} 
podemos ter com os estudantes é ensinar que eles fiquem felizes com sua solidão. Eles vivem dizendo: 'Um pouco de comunicação. Nós nos sentimos sós, somos todos solitários'. Por isso eles querem escolas. Eles não poderão fazer nada em relação à solidão. Temos de ensinar-lhes os benefícios da sua solidão, reconciliá-los com sua solidão. Esse era o meu papel de professor. Diante disso, outro professor responde, se dirige a mim (iria eu tão longe a ponto de dizer meu professor?): Gosto muito da ideia dos alunos procurarem escolas por causa da solidão. Assim é possível justificar a existência da escola pela presença de outros alunos, e não de professores. Talvez por isso os alunos não queiram destruir a escola e desejem, muito menos do que fundar uma escola, inventá-la. Esta esperanza yo no la he buscado. Este pabellón silencioso de la Universidad Desconocida. E se, apesar de tudo, sigo aqui? E se não importa mais estar ou não aqui porque o aqui já se deslocou, está em outra parte? Derrida, em ainda outra ocasião, estamos sempre lendo Derrida: This is another way of calling upon another topology: The university without conditions is not situated necessarily or exclusively within the walls of what is today called the university. It is not necessarily, exclusively, exemplarily represented in the figure of the professor. It takes place, it seeks its place wherever this unconditionality can take shape. Everywhere that it, perhaps, gives one (itself) to think. Sometimes even beyond, no doubt, a logic or a lexicon of the "condition".

¿Cómo se llama esto?, pregunté.

Océano.

Una larga y lenta Universidad. 
introdução

\section{*Página 1}

>> Moby Dick não te procura. És tu, na tua loucura, és tu, que o procuras!

(MELVILLE, Herman. Moby Dick. Trad. Irene Hirsch e Alexandre Barbosa de Souza. São Paulo: Cosac Naify, 2013.)

\section{1. tentativa: junho}

\section{* Página 12}

\> Democracia - a aparição tumultuosa e ruinosa, a chegada fúnebre do demos.

\section{* Página 18}

>> deseja criar o contexto por meio do qual terá garantido que seus atos de fala tinham sido devidamente autorizados por um contexto autorizante. Os atos de fala do manifesto são então lançados em um futuro anterior, declarando que a sua autoridade terá sido proporcionada pelas mudanças que eles mesmo querem realizar.

\section{sonhos, uma segunda introdução}

\section{* Páginas 21-22}

>> Mas então, você diz, o pensamento não pega no sono e dá passagem a fantasias? / Não o considere por um segundo. Embora permaneça sendo verdade - dolorosamente verdade - que o sono da razão dá à luz a monstros, não é menos verdade que é ao se deixar inclinar o sono, ao sonho, e à possibilidade de não mais despertar que o pensamento se deixa despertar para o último dia possível de sua probidade plena: o primeiro dia, o dia sem dia da nossa eternidade santa.

\section{* Página 25}

>> Uma confidência, para terminar. Talvez eu apenas quisesse confiar ou confirmar meu gosto (provavelmente incondicional) pela literatura, mais precisamente, pela escritura literária. Não que eu ame a literatura em geral nem que a prefira ao que quer que seja, por exemplo, como pensam muitas vezes aqueles que não discernem por fim nem uma nem outra com relação à filosofia. Não que eu queira reduzir tudo a ela, e menos ainda, à filosofia. No fundo, passo sem a literatura, de fato, com bastante facilidade. Se precisasse me retirar para uma ilha, no fundo seriam os livros de história, de memórias que provavelmente levaria comigo e que leria à minha 
maneira, talvez para deles fazer literatura, a menos que fosse o inverso, e isso seria verdadeiro a respeito dos outros livros (arte, filosofia, religião, ciências humanas ou naturais, direito etc.). Entretanto, se, sem amar a literatura em geral e por ela mesma, amo alguma coisa nela que não se reduz de modo algum a uma qualidade estética, a uma fonte de fruição formal, isso seria em lugar do segredo. Em lugar de um segredo absoluto. Aí estaria a paixão. Não há paixão sem segredo, estre segredo, mas não há segredo sem paixão. Em lugar do segredo: aí, entretanto, onde tudo está dito e o resto nada mais é senão o resto, nem mesmo a literatura.

(DERRIDA, Jacques. Paixões. Trad. Lóris Z. Machado. Campinas: Papirus, 1995.)

\section{* Página 26}

> > eu quero fazer um elogio ao sono. Não como praticante-admito que nunca pude ser o que é chamado de "uma boa dormidora" e talvez seja possível retornar depois a esse conceito curioso - mas como leitora. Há tanto sono para ser lido, há tantas maneiras de lê-lo.

\> Foi na casa em que eu morava quando tinha três ou quatro anos. Eu sonhei que estava dormindo na casa, em um quarto no andar de cima. Que eu acordei e desci para o andar de baixo e fiquei de pé na sala. As luzes estavam acesas na sala, embora estivesse quieto e sem ninguém. O sofá e as cadeiras verdes escuras de sempre se encostavam nas paredes verdes claras de sempre. Era a mesma velha sala de sempre, eu a conhecia bem, nada estava fora do lugar. E no entanto ela estava absolutamente, certamente, diferente. Dentro de sua aparência de sempre a sala estava mudada como se ela tivesse enlouquecido.

\section{* Página 27}

\> quando alguém fala dos pés da mesa ou da face da montanha a catacrese já está virando prosopopeia e começa-se a perceber um mundo de fantasmas e monstros em potencial.

〉> Então, até onde posso recordar, eu explique o sonho a mim mesma dizendo que eu tinha pegado a sala dormindo. Eu tinha entrado nela pelo lado do sono.

\section{* Páginas 27-28}

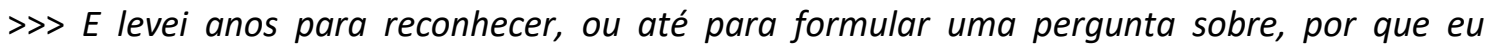
considerava essa entrada na estranheza tão supremamente consoladora. Pois apesar de sinistra, inexplicável e da depois trágica referência à sala verde, foi e permanece para mim um consolo pensar nela deitada ali, afundada no seu verdejar, respirando sua própria ordem, não respondendo a ninguém, aparentemente penetrável por todos os lados e ainda assim 
perfeitamente disfarçada em toda a propaganda de sua vida desperta como se a tornar-se em sentido verdadeiro algo incógnito no coração da nossa casa adormecida.

\section{* Página 28-29}

>> vista pelo lado do sono, uma órbita de olho vazia é só um fato sobre uma pessoa, não um desejo a ser realizado, não um desafio terapêutico.

\section{* Página 29}

〉> foi e permanece para mim um consolo pensar nela deitada ali, afundada no seu verdejar, respirando sua própria ordem, não respondendo a ninguém.

\section{* Página 31}

〉> eu durmo e esse eu que dorme não pode dizer que dorme na mesma medida em que não poderia dizer que está morto. Então é outro que dorme em meu lugar.

〉> é o outro em mim quem - ou que - decide.

\section{* Página 34}

〉> de fato os sonhos não ficavam confinados a ela, mas iam de um cérebro a outro. Todos eles sonharam com cada um dos outros naquela noite, como era natural, considerando a finura das divisórias entre eles e a estranheza com que haviam sido erguidos da face da terra para sentarem-se um ao lado do outro em alto-mar...

\section{$\underline{2.1 \text { hipnose }}$}

\section{* Página 36-37}

>> McDonald foi preso e confessou a tudo, mas insistiu que ele estava sob a influência de Gray e não pôde fazer nada além de agir de acordo com as "sugestões" de seu mestre hipnotizador. Ele admitiu, sem hesitar, ao assassinato de Patton, mas recusou considerar-se como o o verdadeiro assassino. Ele insistiu que não teria motivações para o crime, e que embora ele soubesse o que estava fazendo, lembrava do ato com uma indefinição de sonho e não havia percebido no momento as consequências de suas ações. Ele disse que se não tivesse sido por Gray ele não teria nunca conversado com Patton, e se não fosse pela "sugestão" do hipnotizador ele não teria praticado com o rifle e jamais teria atirado contra a vítima. 


\section{* Página 37}

>> HIPNOSE COMO DEFESA - História do caso em que o verdadeiro assassino foi inocentado e o hipnotizador condenado.

>> a condição hipnótica já não é objeto de especulação. Ela se destaca como uma das forças reconhecidas da vida, e qualquer tribunal diante do qual ela aparecer relacionada deve reconhecê-la.

\section{* Página 41}

>> ação criminosa combinada de linchadores, amotinadores, e turbas.

\section{* Páginas 45-46}

〉> seja você meu corpo por mim, mas não me deixe saber que o corpo que você é é o meu corpo. Uma injunção e contrato aqui são performativizados de tal maneira que os movimentos que garantem o cumprimento da injunção $e$ do contrato são imediatamente encobertos $e$ esquecidos.

\section{2 drones}

\section{* Página 49}

\> A visão nesse banquete tecnológico transforma-se em gula desregulada; toda a perspectiva dá lugar a uma visão infinitamente móvel que não parece mais ser o truque mitológico de deus de ver tudo de lugar nenhum, mas de colocar o mito em prática ordinária. E como o truque de deus, esse olho fode o mundo para dar origem a tecnomonstros.

\section{* Página 52}

\> 5000 pés é o melhor. A 5000 pés eu posso te dizer o tipo de sapato que você está usando de uma milha de distância. Eu posso saber a roupa da pessoa, a cor da barba e do cabelo. Temos o modo infravermelho que podemos acionar automaticamente e isso vai detectar assinaturas de calor ou de frio. Quer dizer, se alguém se senta em uma superfície fria por um tempo e depois se levanta, ainda dá para ver o calor daquela pessoa ali por muito tempo. / Parece meio que com uma flor fria desabrochando no paraíso. / É muito bonito. / Quer dizer, se alguém acende um cigarro é um sinal luminoso enorme que dá para ver, você vê um brilho muito branco vindo daquela área e você pode segui-los e eles não vão te ver ou escutar. 
>> Nota 16: a obra de arte mais grandiosa possivel em todo o cosmos (...) tem pessoas que estão tão concentradas em uma única performance, e aí 5000 pessoas são despachadas para a eternidade, em um único momento. Eu não poderia fazer isso. Em comparação a isso, não somos nada como compostiores.

\section{* Página 53}

\> E então fazemos algo chamado de a "luz de Deus" - os fuzileiros navais gostam de chamar de "luz de Deus" - é um marcador de alvos a laser. Nós simplesmente enviamos um raio de laser e quando as tropas colocam seus óculos de visão noturna, eles podem ver essa luz que parece estar vindo do paraíso, bem ali. Vindo de lugar nenhum. É muito bonito.

>> À vezes me sinto como um Deus jogando raios de muito longe.

\section{* Página 54}

>>> esses humanos estão constituídos de modo a fazê-los resistirem aos chamados de sua humanidade e são convocados a conformarem-se ao drone. A perspective presciente de Adorno confirma que a conquista de uma "dessubjetivação" não é mero efeito da automação, mas um trabalho realizado pelo sujeito que opera nele mesmo o processo de auto-automação, ou da criação de "eu automático".

>> Nota 17: EU MESMO EXECUTEI, EM 1918 [durante a guerra, portanto], MUITOS VOOS EXPRESSIVOES E TESTES DE TEATRO AÉREO ELEMENTAR SOBRE O CAMPO DE BUSTO ARSIZIO. EU constatei como é fácil para os espectadores seguirem todas as matizes do estado de ânimo do aviador, dada a identificação absoluta entre o piloto e o seu aparelho, que é como um prolongamento do corpo: os ossos, tendões, músculos e nervos se extendem à longarina e aos fios metálicos.

〉> Isto é para desafiar certos discursos de "aceleração" que consideram a resistência como algo ligada à capacidade do excesso, da ausência de friçcão, da hipertrofia, e assim por diante, que são defendidas como modos de ultrapassar as formas do poder militar, estatal e capitalista. $O$ desejo de uma desterritorialização final que pode dar passagem ao espaço liso da resistência não só é desleal ao aviso de Deleuze e Guattari "nunca acredite que um espaço liso bastará para nos salvar", mas como também permanece dentro do âmbito da metafísica dos drones. 


\section{* Página 58}

>>> Com base em hábitos antigos, podemos nos ver tentadas a dizer, "mas se ele (o corpo) significa, ele é certamente discursivo", e talvez isso seja verdade. Mas essas réplicas, mesmo que ela se sustente, não nos deixa examinar essa importante relação quiasmática entre formas de performatividade linguística e formas de performatividade corporais. Elas se sobrepõem; não são de todo diferentes; não são, no entanto, idênticas entre si.

\section{* Página 63}

>> como ver o universo morrendo num período de mais ou menos sete bilhões de anos.

(DELILLO, Don. Ponto Ômega. Tradução de Paulo Henriques Britto. São Paulo: Companhia das Letras, 2011.)

>> Todos se lembram do nome do assassino, Norman Bates, mas ninguém se lembra do nome da vítima. Anthony Perkins é Norman Bates, mas Janet Leigh é Janet Leigh. Exige-se da vítima que tenha o moesmo nome que a atriz que a representa. (Ibid.)

\section{* Página 64}

\> dos metafísicos das agências de informações, dos fantasistas do Pentágono / resgatar o corpo. (Ibid.)

\> tentamos criar novas realidades da noite pro dia, sequências cuidadosas de palavras que eram como slogans de publicidade de tão memoráveis e repetíveis que eram. Palavras que geravam imagens e ai se tornavam tridimensionais. (Ibid.)

\> Etimologia e prisões secretas. Latim vulgar e tortura por procuração. $O$ ensaio se concentrava no estudo da palavra em si, a primeira ocorrência no idioma, mudanças de forma e significado, formas de grau zero, formas reduplicadas, formas sufixadas. Havia notas de rodapé que eram como ninhos de cobras. Porém nada se falava sobre prisões secretas, Estados de deportação nem tratados e convenções internacionais. (Ibid.)

\footnotetext{
* Página 65

>> uma palavra que fora utilizada para sintetizar e ocultar o assunto vergonhoso a que ela se referia. (Ibid.)
} 


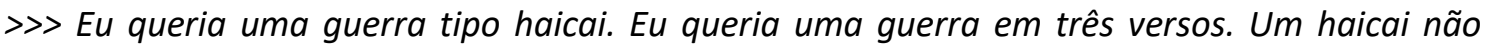
significa nada além do que é. Essa é a essência do haicai. Expor tudo a olho nu. (Ibid.)

〉> mas naquela sala, com aqueles homens, eram só prioridades, estatísticas, avaliações, racionalizações

(lbid.)

>>> o sonho de extinção.

(Ibid.)

>> agora é voltar pra matéria inorgânica. é isso que nós queremos. queremos ser pedras num campo.

(Ibid.)

>>> olhar para ela me perturbava, por saber que ela não se sentia observada.

(Ibid.)

\section{* Página 66}

>> Nós temos que ser humanos para sempre?

(Ibid.)

>> Você está protegendo o quê? Ela é louca. Pode dizer.

(lbid.)

\section{* Página 67}

>> sobre a pornografia, independente de quão sistemáticos sejam os seus efeitos discriminatórios, não é possível dizer que ela discrimina contra mulheres em si mesma e, portanto, deve contar, pelo menos legalmente, como uma forma protegida de expressão. (Ibid.)

\section{3 radiação}

\section{* Página 69}

> > o rompimento do espelho seria, finalmente, por meio de um ato de linguagem, a ocorrência mesma da guerra nuclear. Quem pode jurar que o nosso inconsciente não está esperando isso? sonhando com isso, desejando isso? 
〉> No começo terá havido velocidade.

\section{* Página 70}

>> Assim como toda linguagem, toda escrita, todo texto poético-performativo ou teoréticoinformativo despacha, se envia, se deixa ser enviado, também os misseis de hoje, quaisquer que sejam seus fundamentos, se permitem ser descritos mais prontamente do que nunca como despachos escritos (código, inscrição, traço, e assim por diante). Isso não os reduz à inofensividade obtusa que alguns inocentemente atribuiriam aos livros. Ela recorda (expõe, explode) aquilo que, na escrita, sempre inclui o poder de uma máquina de morte.

\section{* Página 71}

\>> A literatura não está reduzida a essa forma de arquivamento e a essa forma de lei, mas ela não poderia sobreviver a elas e ainda ser chamada de literatura.

\section{* Página 72}

>>> Agora o que nos permite, talvez, pensar sobre a singularidade da guerra nuclear, o seu serpela-primeira-vez-e-talvez-pela-última-vez, sua absoluta inventividade, o que ela nos impele a pensar mesmo que se mantenha como um engodo, uma crença, uma projeção fantasmática, é obviamente a possibilidade de uma destruição irreversível, deixando nenhum rastro do arquivo jurídico-literário - isto é, a destruição total da base da literatura e da crítica. Não necessariamente a destruição da humanidade, ou do habitat humano, nem mesmo de outros discursos (artes ou ciências), nem mesmo de fato da poesia ou da épica; essas últimas podem vir a reconstituir se processo vivo e se arquivo, pelo menos na medida em que a estrutura daquele arquivo (o da memória não-literária) implica, estruturalmente, referência a um referente real externo ao arquivo em si. Estou tomando cuidado para dizer: nessa medida, e sob essa hipótese.

\section{* Páginas 72-73}

〉> Isso nos levaria a uma extensão considerável - alguns diriam abusiva - do campo da literatura. Mas quem comprovou que a literatura é um campo com limites indivisíveis e simplesmente assinaláveis? Os eventos conhecidos pelo nome da literatura são definíveis; e há em princípio uma história possível desse nome e das convenções ligadas à nomeação. Mas o mesmo não pode ser dito das possibilidades estruturais daquilo que se chama de literatura, cujos limites não se encontram nos eventos já conhecidos sob esse nome. 


\section{* Página 73}

>> A hipótese dessa destruição total zela pela desconstrução, guia seus passos; passa a ser possivel reconhecer, à luz, por assim dizer, dessa hipótese, dessa fantasia, ou fantasma, as estruturas características e a historicidade dos discursos, estratégias, textos, ou das instituições a serem desconstruídas.

\section{* Página 74}

\> Podemos daqui em diante afirmar que a historicidade da literatura é contemporânea do início ao fim, ou mais bem estruturalmente indissociável, de algo como a época nuclear (por "época" nuclear, eu também quero dizer a epoché suspendendo julgamento diante da decisão absoluta). A era nuclear não é uma época, ela é a epoché absoluta; não é o conhecimento absoluto e o fim da história, é a epoché do conhecimento absoluto. A literatura pertence a essa época nuclear, essa da crise e da crítica nuclear, pelo menos se quisermos com isso dizer o horizonte histórico e ahistórico de uma auto-destrutibilidade sem apocalipse, sem revelação de sua própria verdade, sem conhecimento absoluto.

\section{* Páginas 75-76}

> > O único assunto de toda a literatura possível, toda a crítica possível, seu único referente derradeiro e assimbólico, insimbolizável, até insignificável; isto é, se não da era nuclear, se não da catástrofe nuclear, pelo menos aquilo em direção ao qual o discurso nuclear e o simbólico nuclear estão chamando: a destruição assimbólica e sem restos da literatura. A literatura e a crítica literária não podem falar de outra coisa, elas não podem ter nenhum outro referente derradeiro, elas podem apenas multiplicar suas manobras estratégicas de modo a assimilar aquele inassimilável outro absoluto. Não são nada mais que as manobras e a estratégia diplomática, com toda a fala ambígua que não pode ser jamais reduzida a elas.

\section{* Página 76}

〉> e em verdade eu acredito que se lida com a época nuclear de maneira mais "séria" em textos de Mallarmé, ou Kafka, ou Joyce, por exemplo, do que em romances atuais que ofereceriam descrições diretas e realistas de uma catástrofe nuclear "real".

\footnotetext{
* Página 77

>> um míssil absoluto não abole o acaso.
} 


\section{* Página 81}

〉> é o fim desse mundo que conhecemos, e eu me sinto bem (já era hora de ter um tempo sozinho).

\section{* Página 83}

\> Precisa haver um jeito bom e um jeito mal de lidar com essa indistinção. E o jeito mal que o autor precisa corporificar na sua personagem. Ele precisa construir a personagem como o seu oposto, como o anti-artista. O jeito bom, o jeito artístico de se lidar com a indistinção, consiste em enfiá-la no livro, no livro enquanto livro. O jeito mal, o jeito da personagem, consistem em enfiá-la na vida real.

\section{* Páginas 85-86}

>> Coma, beba, engula minha letra, porte-a, transporte-a em você como a lei de uma escritura tornada seu corpo: a escritura em si. A astúcia da injunção pode inicialmente deixar-se inspirar pela simples possibilidade da morte, pelo perigo que um veículo traz a todo ser finito. Você ouve a catástrofe vir. Desde então, impresso sobre o próprio traço, vindo do coração, o desejo do mortal desperta em você o movimento (contraditório, está me acompanhando?, dupla restrição, imposição aporética) de proteger do esquecimento esta coisa que ao mesmo tempo se expõe à morte e se protege - em uma palavra, o porte, a retração do ouriço, como na estrada um animal enrolado em bola. Gostaríamos de pegá-lo nas mãos, aprendê-lo e compreendê-lo, guardá-lo para nós, junto de nós.

(DERRIDA, Jacques. “Che cos'è la poesia?” Trad. Tatiana Rios e Marcos Siscar. In: Inimigo Rumor, 10, maio de 2001.)

\section{3. ezln}

\section{* Página 92}

〉> acontecendo como o estar-junto da alteridade

\section{* Página 94}

〉> isto é, ele se reemite enquanto realmente soa, o que já é "re-soar" dado que isso nada mais é do que referir-se de volta a si mesmo. Soar é vibrar em si mesmo ou por si mesmo: para o corpo sonoro não é somente, para emitir um som, mas é também para estendê-lo, carregar-se a si mesmo e ser resolvido em vibrações que tanto retornam a si mesmas quanto se colocam fora de si mesmas. 


\section{* Página 96}

>> rumo a sua permanência.

\section{* Página 97}

>> é necessário falar do fantasma, de fato para o fantasma e com ele, desde que nenhuma ética, nenhuma política, revolucionária ou não, parece ser possível ou pensável e justa que não reconhece em seu princípio o respeito por aqueles outros que já não estão ou para aqueles outros que ainda não estão, vivendo no presente, estejam eles já mortos ou ainda por nascer.

\section{* Página 99}

〉> Próximo: não se pode falar de uma geração de caveiras ou espíritos [...] exceto na condição da linguagem - e a voz, em todo caso daquilo que marca o nome ou toma o seu lugar ("Hamlet: Houve tempo em que esta cabeça tinha uma língua e cantava")

\section{* Página 100}

>> quando o subalterno é postulado como a causa e não o efeito constitutivo negativo da relação político-intelectual, a linha entre "pode o subalterno falar" e "como pode o subalterno [ser pressionado] a falar?" é indistinguível.

〉> em outras palavras, o silêncio zapatista é disruptivo para o discurso hegemônica porque ele é simplesmente "barulhento" e silencioso simultaneamente, ou porque, para além do barulho, esse silêncio é realmente uma forma de fala?

\section{* Página 102}

>> o vazio irruptivo - radicalmente ilegível - dentro da própria significação.

〉> enunciação incomensurável da "verdade" como exterioridade, nem o nome de sua corporificação autêntica

\section{* Páginas 102-103}

>> talvez seja necessário que o sentido não encontre satisfação em fazer sentido (ou em ser logos), mas que ele também queira ressoar. 


\section{* Página 103}

>>> o problema é saber se os sujeitos que importam na interlocução "são" ou "não são", se eles estão falando ou somente fazendo barulho. É saber se há um argumento para ver o objeto designado por eles como o objeto visível do conflito. É saber se a língua comum em que eles estão expondo uma injustiça trata-se de fato de uma língua comum. A discussão não tem nada a ver com conteúdos linguísticos mais ou menos transparentes ou opacos; tem a ver com a consideração de seres falantes como seres falantes.

>> o estado de exceção não é nem externo ou interno à ordem jurídica, e o problema de definilo diz respeito precisamente a uma brecha, ou a uma zona de indiferença onde dentro e fora não se excluem, mas em realidade se misturam.

\section{* Páginas 105-106}

\> como propõe o EZLN, não se trata de uma campanha em prol da vitória eleitoral (isto é, não em prol da hegemonia, contra-hegemonia, consenso ou homogeneidade) mas em prol de uma comunicação geradora de vida em meio aos rastros da ruína.

\section{* Página 107}

>>> uma crítica absolutamente incondicional das bases do poder soberano.

\section{4. feminicídios}

\section{* Página 113}

>> Nota 33: 116 mil moradias abandonadas, 80 mil comércios fechados, 10 mil crianças órfãs e 200 mil familas exiladas.

\section{* Página 116}

>> a fábrica opaca seria então, no seu extremo, a antecâmara da máquina de feminicídio, um 'campo' excepcional, como descrito por Agamben.

\section{* Página 117}

\> falar dentro desses contextos clássicos de corpos que importam não é um jogo inerte de palavras, pois ser matéria significa materializar, onde o princípio desta materialização é precisamente o que importa a respeito daquele corpo, a sua inteligibilidade mesmo. Neste sentido, conhecer a significância de alguma coisa é saber como e por que ela importa, onde importar quer dizer ao mesmo tempo "materializar" e "significar". 


\title{
5. animais
}

\section{* Página 134}

>>> especialmente quando a lógica do inconsciente é fundada sobre a lógica da repetição, que, na minha opinião, inscreverá sempre o destino da iterabilidade, por isso o automatismo da reação em cada resposta, não importa quão original, livre, crítica, e a-reativa ela possa parecer.

\begin{abstract}
* Página 135
> > o eco de uma outra fala e de alguma outra coisa que não a fala: uma ecolália, que guardou a memória da balbúrdia indistinta e imemorial que, em se perdendo, permitiu que todas as línguas viessem a ser.
\end{abstract}

\> Em nenhum outro lugar a língua é mais "ela mesma" do que naquele momento em que ela parece partir do terreno de seu som e sentido, tomando a forma sonora daquilo que não é - ou não pode ter - uma língua própria: os animais e seus sons, barulhos naturais ou mecânicos.

\section{* Página 137}

>> "Informação" pode ser definida resumidamente como qualquer diferença que faz diferença em algum evento posterior.

\section{* Página 138}

>> Como a polinização, a comunicação, expressão, e articulação são práticas por meio das quais os organismos se envolvem na vida um dos outros.

> > Wolfgang Köhler provavelmente era um bom homem. Um bom homem, mas não um poeta. (COETZEE, J.M. Elizabeth Costello. Tradução de José Rubens Siqueira. São Paulo: Companhia das Letras, 2004.)

\> Da pureza da especulação - por que os homens se comportam assim? - ele é impiedosamente impelido ao raciocínio mais baixo, prático, instrumental - como usar isto para conseguir aquilo? - e assim à aceitação de si mesmo primordialmente como um organismo com um apetite a ser satisfeito. (Ibid.)

\section{* Página 139}

>> a tirinha faz algo muito especial; ela não confunde atração com identidade; ela não diz que a flor é exatamente como a genitália do inseto. Em vez disso, a flor coleta obliquamente a 
presença da abelha, em desejo e mortalidade. A forma da flora é "uma ideia de como a abelha macho percebia a abelha fêmea ... interpretada por uma planta ... a única lembrança que se tem da abelha é uma pintura feita por uma flor moribunda." Certa vez abraçada pelo zunido das abelhas vivas, a flor é uma porta-voz para os mortos.

\section{* Página 140}

〉> Nota 44: e agora vou ter que perambular sozinho nessa longa conversa que era para nós termos juntos

\section{* Páginas 140-141}

>> Considere que a comunicação não precisa estar limitada a contextos em que pacotes individuais de dados binários são tanto enviados como recebidos. Talvez as proposições feitas pelas plantas não guardem nenhuma relação com os nossos modelos semióticos e sintáticos. Talvez elas não sejam "representações" que buscam, com sucesso ou não, nomear ou servir de espelho a um mundo preexistente. Em uma leitura envolucionária, mecanismos de sinaisresposta dão lugar a ontologias mais vivazes e mundações* intra-ativas.

[*Nota de tradução: Aqui o substantivo mundo dá origem a um verbo, Hustak \& Myers provavelmente se inspiram em Donna Haraway, que diz, it matters which world worlds worlds, ou seja, importa quais mundos mundam mundos. A pergunta se transforma, De que maneira ocorre a transdução de energias e químicas afetivamente carregadas dentro e entre os corpos?]

\footnotetext{
* Página 142

>> a mordiscada de brincadeira denota a mordida, mas não denota o que seria denotado pela mordida.
}

>> Nota 48: figura como o ponto de entrada momentâneo ao universo da pretensão, da ficção, e da simulação, ou para citar o termo grego, da mimese.

\section{post scriptum - para isso continuamos vivas}

\section{* Página 146}

\>> Mas aprender a viver, aprender a viver consigo mesma e por si mesma, completamente só, ensinar-se a si mesma viver ("eu gostaria de saber finalmente viver"), não é isso impossível para um ser vivo? Não é isso o que a própria lógica proíbe? Viver, por definição, não é algo que se aprende. Não consigo mesma, não com a vida, não é a vida que ensina a viver. 


\title{
* Página 147
}

>> Qual é a vista, quais são as vistas da Universidade?

>> O que se vê desde a Universidade?

\begin{abstract}
* Páginas 147-148
>>> O que pode ser o diafragma da Universidade? Será a Universidade mestre de seu próprio diafragma? 0 que pode o corpo da Universidade ver ou não de sua própria destinação, daquilo em cuja vista delimita o seu chão?
\end{abstract}

\begin{abstract}
* Página 148
〉> James Siegel observa (e eu cito) que "para Ezra Cornell a associação da vista da universidade tinha algo que ver com a morte." A pergunta surgiu de novo em 1977, quando a administração da universidade propôs erguer barreiras de proteção na ponte de Collegetown e na ponte suspensa de Fall Creek para prevenir ideações suicidas inspiradas pela vista do desfiladeiro.
\end{abstract}

>>> O que ele quis dizer? Qual é a essência da universidade?

\section{* Página 149}

〉>> Nota 51: Pedagogia sem porquê não significa ensinar de graça ou trabalhar por nada. Ela também se aplica a alunos, que não vão sobreviver se apenas quiser sobreviver. Aqui está a primeira situação espectrológica: aqueles de nós que passamos as nossas vidas na escola nos encontramos entre a dádiva e a economia. Nós levamos vidas assombradas, encantados ou assombrados por um chamado que é muito "fraco" e espectral para ser um imperativo mesmo que seja necessário conduzir o trabalho diário da economia do mundo.

\footnotetext{
* Página 153

〉> Crianças francesas vivas são convocadas a se identificarem com crianças-vítimas judias. Essa identificação produz uma terceira criança - vamos chamá-la de uma criança "virtual", uma criança que ainda está por ser. Essa criança virtual figura em um futuro onde a diferença foi deixada para trás. Há algo perturbadoramente hegeliano nessa superação da criança morta no caminho da transformação rumo a um sujeito moderno da/na história. Uma ironia nova e não menos perversa aparece, então, diante da imagem de crianças francesas muçulmanas sendo convidadas a se identificarem com crianças mortas judias para NÃO se transformarem em "os muçulmanos" que todos já de antemão imaginam que elas são.
} 
> > era majoritariamente apoiado, dentro da universidade, por homossexuais e feministas / um fato que parecia muito significativo para ele [o professor], e sem dúvida um sinal de assexualidade.

\begin{abstract}
* Página 154
>> Qualquer pensamento que não tenha tomado corpo nesse espírito de unidade e totalidade é vazio em si mesmo, e deve ser contestado; aquilo que é incapaz de caber harmoniosamente nessa totalidade florescente e viva é um broto morto que cedo ou tarde será eliminado pelas leis orgânicas; sem dúvida também existem, dentro do âmbito da ciência, inúmeras abelhas sem sexo que, como Ihes foi negada a capacidade de criar, multiplicam em brotos inorgânicos os sinais externos de sua própria incompetência.
\end{abstract}

\footnotetext{
* Página 156

〉> mas nos sentimos mal / quem ousaria dizer outra coisa? E aqueles que se sentem bem estão possivelmente escondendo algo, dos outros ou de si mesmos.
}

\title{
* Página 157
}

〉> Nota 56: A autonomia da avaliação científica pode ser absoluta e incondicionada, mas os efeitos políticos de sua legitimação, mesmo supondo que fosse possível realizar uma distinção rigorosa entre elas, não são menos controladas, medidas e vigiadas por um poder externo à universidade.

\section{* Página 159}

>> Tenha cuidado com aquilo que abre a universidade para o exterior e o sem fundo, mas também com aquilo que, encerrando-se em si mesma, criaria somente a ilusão do encerramento, deixaria a universidade disponível a qualquer tipo de interesse, ou então a tornaria completamente inútil. Cuidado com os fins; mas o que seria da universidade sem os fins?

\footnotetext{
* Página 160

〉> responder ao princípio da razão é o mesmo ato que responder pelo princípio da razão? A cena é a mesma? A paisagem é a mesma? E onde dentro desse espaço está localizada a universidade?
} 
>> Nós não escutamos da mesma maneira quando estamos respondendo a um apelo ou quando estamos questionando o seu sentido, sua origem, sua possibilidade, seu alvo, seus limites. Estamos obedecendo o princípio da razão quando perguntamos o que fundamenta esse princípio que é em si mesmo um princípio de fundamento? Não estamos - o que não quer dizer, por outro lado, que o estejamos desobedecendo. Estamos lidando aqui com um círculo ou com um abismo?

〉> Esse fundamento, então, como a universidade, teria de manter-se suspenso sobre um vazio muito peculiar.

\section{* Páginas 160-161}

〉> quem é mais fiel ao apelo da razão, quem o escuta com um ouvido atendo, quem melhor vê a diferença, aquele que oferece perguntas em troca e busca pensar detidamente sobre a possibilidade desse apelo, ou aquele que não quer escutar nenhuma pergunta sobre a razão da razão?

\section{* Página 161}

>> uma abertura, uma pequena rachadura ou ranhura no sistema, por meio das quais / os frágeis brotos [de novos os brotos] da liberdade, novidade, e diferença poder construir passagem.

\footnotetext{
* Páginas 161-162

>> como uma "ciência" do "limiar", a desconstrução nos ousa a cometer um "atravessamento" e, talvez, ao fazer isso, a evitar o horror de ter a porta da Lei da Lei fechar finalmente nas nossas caras.
}

\section{* Página 162}

\> Nota 58: Sonho. Participando de uma reunião política nacional. Começo a falar. Acuso todo mundo. (Como sempre: nunca formo alianças e disparo em qualquer direção: completamente sozinho. O medo é uma aliança, e a sensação de segurança que mantém a aliança. Eu tenho muito medo disso, o que quer dizer que não há nada heroico em minha solidão - em vez disso algo temeroso e covarde: 'eles não podem me pegar aqui' - e eu começo a buscar a causa em minha fuga da aliança e nojo da 'comunidade'. A palavra em si me embrulha o estômago).

Q: Você chama duas coisas à urgência: deslocar as práticas de leituras e criar uma espécie de comunidade de leitores. 
J.D.: Não gosto muito da palavra comunidade, não tenho nem muita certeza de que gosto da coisa.

Q. Foi você quem a utilizou.

J.D.: Se por comunidade está implícito, como é geralmente o caso, um grupo harmonioso, consenso, e concordância fundamental sob o fenômeno da discórdia ou da guerra, então eu não acredito muito nele e eu intuo nela tanto uma ameaça quanto uma promessa.

\begin{abstract}
* Páginas 162-163
>> Seria a mesma responsabilidade de uma comunidade de pensamento para o qual a fronteira entre a pesquisa básica e orientada não estaria mais assegurada, ou em todo caso não sob as mesmas condições que antes. Eu o chamo de uma comunidade de pensamento em sentido amplo - em geral - no lugar de uma comunidade de pesquisa, de ciência ou filosofia, já que esses valores estão muito frequentemente sujeitos à autoridade inquestionada do princípio da razão.
\end{abstract}

\title{
* Página 163
}

\> Há aqui um gesto duplo, uma dupla postulação: garantir competência profissional e a tradição mais séria da universidade mesmo enquanto se vai o mais longe possível, teoricamente e praticamente, no pensamento mais diretamente subterrâneo sobre o abismo debaixo da universidade, pensar ao mesmo tempo toda a paisagem "cornelliana" - o campus nas alturas, as pontes, e se necessário as barreiras sobre o abismo - e o próprio abismo

\footnotetext{
* Página 164

>> em francês um ubiquista é alguém que viaja muito e viaja rápido, dando a ilusão de estar ao mesmo tempo em toda a parte. Ele está alheio ao contexto, aos rituais apropriados e ao ambiente mudado.
}

>> nos encontramos em uma topografia política implacável: um passo a mais com vistas a uma maior profundidade ou radicalização, até mesmo indo além do "profundo" e do "radical", o principal, a arkhé, um passo a mais em direção a uma espécie de an-arquia original arrisca produzir ou reproduzir a hierarquia. $O$ "pensamento" requer tanto o princípio da razão quanto o que se encontra além do princípio da razão, a arché e a an-arquia. Entre os dois, a diferença de um sopro ou de uma tônica, somente a prática desse "pensamento" pode decidir. Essa decisão é sempre arriscada, ela sempre arrisca o pior. Defender a eliminação desse risco por meio de um programa institucional equivale simplesmente a construir uma barricada contra o futuro. $A$ 
decisão do pensamento não pode ser um acontecimento intra-institucional, um momento acadêmico.

\section{* Página 165}

>> como se com a ajuda de um novo dispositivo óptico fosse possível finalmente ver a vista, não apenas a paisagem natural, a cidade, a ponte e o abismo, mas fosse possível ver a visão. Como se por meio de um dispositivo acústica fosse possível ouvir a audição, em outras palavras, captura o inaudivel em uma espécie de telefonia poética.

\section{* Página 166}

>> Estou entediado/Estou entendiado/Sou o presidente dos entediados.

[Nota de tradução: a brincadeira está na homofonia entre bored (entediado) e board (lousa, mas também conselho, no caso, de "chairman of the board").]

〉> ao nos entediarmos com algo estamos precisamente ainda nas garras daquilo que é entediante, não o deixamos ir, ou somos compelidos por ele, estamos atados a ele por qualquer razão.

\section{* Página 167}

\> Esta é outra forma de convocar outra topologia: A universidade sem condições não está situada necessariamente ou exclusivamente dentro dos muros daquilo que é hoje chamado de universidade. Ela não é necessariamente, exclusivamente, exemplarmente representada na figura do professor. Ela toma lugar, busca seu lugar onde quer que essa incondicionalidade possa tomar forma. Em todo lugar onde ela, talvez, (se) dá a pensar. Às vezes até além, sem dúvida, da lógica ou do léxico da "condição". 
\bibliografia/

\section{introdução}

BENJAMIN, Walter. Sobre o conceito da história. In: Magia e técnica, arte e política. Ensaios sobre literatura e história da cultura. Obras escolhidas. V.1. São Paulo: Editora Brasiliense, 1987.

BLANCHOT, Maurice. The Writing of Disaster. trans. Ann Smock. Lincoln: University of Nebraska Press, 1986.

BOLAÑO, Roberto. "Me lavo los dientes...". In: La universidad desconocida. Barcelona: Anagrama, 2007.

BOLAÑO, Roberto. Tu lejano corazón. In: La universidad desconocida. Barcelona: Anagrama, 2007.

DELEUZE, Gilles. A literatura e a vida. In: Crítica e Clínica. Tradução de Peter Pál Pelbart. São Paulo: Editora 34, 1997.

DERRIDA, Jacques. Some statements and truisms about neo-logisms, newisms, postisms, parasitisms, and other small seismisms. In: CARROL, David (Ed.). The states of 'Theory': History, Art, and Critical Discourse. Stanford: Stanford University Press, 1994.

KOPENAWA, Davi; ALBERT, Bruce. A queda do céu. Palavras de um xamã yanomami. São Paulo: Companhia das Letras, 2015.

MELVILLE, Herman. Moby Dick. Londres: Penguin Classics, 2009.

MELVILLE, Herman. Moby Dick. Trad. Irene Hirsch e Alexandre Barbosa de Souza. São Paulo: Cosac Naify, 2013. 


\section{1. tentativa:junho}

BADIOU, Alain. A hipótese comunista. São Paulo: Boitempo, 2012.

"Black blocks agem com inspiração fascista, diz filósofa a PMs do Rio". In: Folha de São Paulo. 27 de agosto de 2013. Disponível em:

http://www1.folha.uol.com.br/fsp/poder/126068-black-blocs-agem-com-inspiracaofascista-diz-filosofa-a-pms-do-rio.shtml

BLANCHOT, Maurice. Marx's Three Voices. In: Friendship. Stanford: Stanford University Press, 1997.

BOLAÑO, Roberto. 2666. Barcelona: Anagrama, 2010.

BOLAÑO, Roberto. Déjenlo todo, nuevamente. Manifiesto Infrarrealista. In: tsunun (ed.). Nada utópico nos es ajeno. León: tsunun, 2013.

Disponível em: https://tsunun.files.wordpress.com/2013/05/nada-utc3b3pico-nos-esajeno-manifiestos-infrarrealistas1.pdf

BOLAÑO, Roberto. Dentistas. In: Putas Asesinas. Barcelona: Anagrama, 2001.

BOLAÑO, Roberto. El provocador. In: El secreto del mal. Barcelona: Anagrama, 2007.

BOLAÑO, Roberto. "Llegué a los Estadios con mucho frío, patrón...". In: La universidad desconocida. Barcelona: Anagrama, 2007.

BOLAÑO, Roberto. Los detectives helados. In: La universidad desconocida. Barcelona: Anagrama, 2007.

BOLAÑO, Roberto. Los detectives salvajes. Barcelona: Anagrama, 1998. 
BOLAÑO, Roberto. Los neochilenos. In: La universidad desconocida. Barcelona: Anagrama, 2011.

BOLAÑO, Roberto. Los pasos de Parra. In: Los perros románticos: Poemas 1980-1998. Barcelona: Lumen, 2000.

BOLAÑO, Roberto. Los sinsabores del verdadero policía. Barcelona: Anagrama, 2011.

BOLAÑO, Roberto. "Raro oficio gratuito...". In: La universidad desconocida. Barcelona: Anagrama, 2007.

BOLAÑO, Roberto. "Ya no hay imágenes, Gaspar, ni metáforas en la zona...". In: La universidad desconocida. Barcelona: Anagrama, 2007.

COMITÊ Invisível. A insurreição que vem. Tradução: Edições Baratas. Disponível em: https://edicoesbaratas.wordpress.com/2013/07/04/a-insurreicao-que-vem/

COMITÊ Invisível. Aos nossos amigos: crise e insurreição. Tradução: Edições Antipáticas. São Paulo: n-1 edições, 2016.

HUGO, Victor. Os miseráveis. Tradução de Frederico Ozanam Pessoa de Barros. São Paulo: Companhia das Letras, 2017.

LEGUME, Lucas. O Movimento Passe Livre acabou? Disponível em: http://passapalavra.info/2015/08/105592

MARISTAIN, Mónica. Estrella distante, la última entrevista de Roberto Bolaño. Página 12, Buenos Aires, 23 de julho de 2003.

PUCHNER, Martin. Poetry of the Revolution: Marx, Manifestos and the Avant-Gardes. Princeton: Princeton University Press, 2006. 
WILLIAMS, Gareth. The Mexican Exception and the 'Other Campaign'. In: South Atlantic Quarterly 106:1, Winter 2007.

\section{sonhos, uma segunda introdução}

AGAMBEN, Giorgio. Sobre a dificuldade de ler. (Comunicação oral realizada na Feira da Pequena Editora, Roma, 2012). Tradução de Claudio Oliveira. Disponível em: http://www.santoandre.sp.gov.br/biblioteca/bv/hemdig_txt/130617014m.pdf

BARTHES, Roland. Da leitura. In: O rumor da língua. São Paulo: Martins Fontes, 2004.

BERADT, Charlotte. Sonhos no Terceiro Reich. São Paulo: Três Estrelas, 2017.

BENJAMIN, Walter. Passagens. Belo Horizonte: Editora UFMG e São Paulo: Imprensa Oficial, 2009.

BLANCHOT, Maurice. O espaço literário. Rio de Janeiro: Rocco, 1987.

BOLAÑO, Roberto. El monje. In: La universidad desconocida. Barcelona: Anagrama, 2007.

BORGES, Jorge Luis. Libro de sueños. Madrid: Alianza Editorial, 2002.

CARSON, Anne. Every Exit is an Entrance (A Praise of Sleep). In: Decreation: Poetry/Essays/Opera. Nova lorque: Alfred A. Knopf, 2005.

DANOWSKI, Déborah. Dic cur hic? Ou o que significa estar aqui. In: LEVY, Lia; PEREIRA, Luiz Carlos, ZINGANO, Marco. Metafísica, lógica e outras coisas mais. Rio de Janeiro: Nau, 2012.

DE MAN, Paul. Aesthetic Ideology. Minneapolis: University of Minnesota Press, 1996. 
DERRIDA, Jacques. Passions. In: On the Name. Stanford: Stanford University Press, 1995.

DERRIDA, Jacques. Paixões. Trad. Lóris Z. Machado. Campinas: Papirus, 1995.

DERRIDA, Jacques. As If It Were Possible, 'Within Such Limits,'. In: Negotiations: Interventions and Interviews, 1971-2000. Stanford: Stanford University Press, 2002.

GLOWCZEWSKI, Barbara. Devires totêmicos: cosmopolítica do sonho. São Paulo: n-1 edições, 2015.

GORBACH, Frida. El monstruo, objeto imposible: un estudio sobre teratología mexicana, siglo XIX. Cidade do México: Itaca, 2008.

FREITAS, Angélica. Eu durmo comigo. In: Um útero é do tamanho de um punho. São Paulo: Companhia das Letras, 2017.

KOPENAWA, Davi; ALBERT, Bruce. A queda do céu. São Paulo: Companhia das Letras, 2015.

MELO NETO, João Cabral de. O fim do mundo. In: Obra completa: volume único. Marly de Oliveira (org). Rio de Janeiro: Nova Aguilar, 2003.

MENDES, Murilo. A mulher do fim do mundo. Poesia completa e prosa. Luciana Stegagno Picchio (ed.). Rio de Janeiro: Editora Nova Aguilar, 1995.

NANCY, Jean-Luc. The Fall of Sleep. Nova lorque: Fordham University Press, 2009.

NELSON, Maggie. The Argonauts. Minneapolis: Graywolf Press, 2015.

RIVAS, Rubén Peretó. El itinerario medieval de la acedia. In: Intus-Legere Historia, v.4, n.1, 2010. 


\section{$\underline{2.1 \text { hipnose }}$}

ANDRIOPOULOS, Stefan. Aparições espectrais: O idealismo alemão, o romance gótico e a mídia óptica. Rio de Janeiro: Contraponto, 2014.

ANDRIOPOULOS, Stefan. Possuídos: Crimes hipnóticos, ficção corporativa e a invenção do cinema. Rio de Janeiro: Contraponto, 2014.

AZARI, Fedele. II teatro aereo futurista. Reprodução digital disponível no portal archIVI cittá del archivi, pertencente ao acervo de Michele Leskovic. Tradução ao inglês: Futurist Aerial Theatre. The Drama Review: TDR, v.15, n.1, 1970.

BETHURUM, Dorothy. Stylistic Feature of the Old English Laws. The Modern Language Review, v.27, n.3, julho de 1932.

BRETON, André. Manifesto do surrealismo. In: Manifestos do surrealismo. Rio de Janeiro, Nau, 2001.

BOLAÑO, Roberto. 2666. Barcelona: Anagrama, 2010.

BUTLER, Judith. The Psychic Life of Power: Theories in Subjection. Stanford: Stanford University Press, 1997.

Hypnotism as a Defence. In: The New York Times, 8 de abril de 1895.

KANT, Immanuel. Sonhos de um visionário explicados por sonhos da metafísica. In: Escritos pré-críticos. São Paulo: Ed. Unesp, 2005.

TRUMBULL LADD, George. Legal Aspects of Hypnotism. In: The Yale Law Journal, v.11, $\mathrm{n}$. 4, fevereiro de 1902. 


\section{2 drones}

BARTHES, Roland. A Morte do Autor. In: O rumor da língua. São Paulo: Martins Fontes, 2004.

BAUER, Nancy. How to Do Things with Pornography. In: How to Do Things with Pornography. Cambridge: Harvard University Press, 2015.

BENJAMIN, Walter. Para a crítica da violência. In: Escritos sobre mitos e linguagem. São Paulo: Editora 34, 2013.

BENJAMIN, Walter. Sobre o conceito da história. In: Magia e técnica, arte e política. Ensaios sobre literatura e história da cultura. Obras escolhidas. V.1. São Paulo: Editora Brasiliense, 1987.

BRETON, André. Manifesto do surrealismo. In: Manifestos do surrealismo. Rio de Janeiro, Nau, 2001.

BOLAÑO, Roberto. Estrella distante. Barcelona: Anagrama, 2001.

BUTLER, Judith. Notes Toward a Performative Theory of Assembly. Cambridge: Harvard University Press, 2015.

CHAMAYOU, Grégoire. Teoria do drone. São Paulo: Cosac Naify, 2015.

CRARY, Jonathan. 24/7 - Capitalismo tardio e os fins do sono. São Paulo: Cosac Naify, 2014.

DELILLO, Don. Point Omega. Nova Iorque: Charles Scribner's Sons, 2010.

DELILLO, Don. Ponto Ômega. Tradução de Paulo Henriques Britto. São Paulo: Companhia das Letras, 2011. 
DERRIDA, Jacques. Force of Law: 'The Mystical Foundation of Authority'. In: Acts of Religion. Nova Iorque, Routledge: 2002.

DERRIDA, Jacques. Passions. In: On the Name. Stanford: Stanford University Press, 1995.

DERRIDA, Jacques. Racism's Last Word. In: Critical Inquiry, 12:1 (Autumn, 1985).

DERRIDA, Jacques. 'This Strange Institution Called Literature' An Interview with Jacques Derrida. In: Acts of Literature. Nova lorque: Routledge, 1992.

FOUCAULT, Michel. O que é um autor? In: Estética, Literatura e Pintura, Música e Cinema. Rio: Forense Universitária, 2009.

HARAWAY, Donna. Simians, Cyborgs, and Women: The Reinvention of Nature. Nova Iorque: Routledge, 1991.

NODARI, Alexandre. A literatura como antropologia especulativa. In: Revista da Anpoll, n.38, Jan/Jun de 2015.

NOYS, Benjamin. Drone Metaphysics. In: Culture Machine, v.16, 2015.

ROCHA, Alexandre Caroli. A poesia transcendente de Parnaso do além-túmulo. Dissertação - Unicamp. Campinas, 2001.

UEXKÜLL, von Jacob. Dos animais e dos homens. Lisboa: Livros do Brasil, 1982.

\section{$\underline{2.3 \text { radiação }}$}

ALEKSIÉVITCH, Svetlana. Vozes de Tchernóbil: A história oral do desastre nuclear. São Paulo: Companhia das Letras, 2016. 
DERRIDA, Jacques. Che cos'è la poesia? In: KAMUF, Peggy. A Derrida Reader: Between the Blinds. Nova lorque: Columbia University Press, 1991.

DERRIDA, Jacques. Che cos'è la poesia? Tradução de Tatiana Rios e Marcos Siscar. In: Inimigo Rumor, 10, maio de 2001.

DERRIDA, Jacques. No apocalypse, not now. In: Diacritics 14(2), Nuclear Criticism, 1984.

FUKUYAMA, Francis. The End of History and the Last Man. Nova lorque: Free Press, 1992.

NANCY, Jean-Luc. After Fukushima: The Equivalence of Catastrophes. Nova Iorque: Fordham University Press, 2015.

RANCIÉRE, Jacques. The Politics of Literature. Malden: Polity Press, 2011.

\section{$\underline{\text { 3. ezln }}$}

ACOSTA, Abraham. Contingencies of Silence: Subalternity, the EZLN, and the Accounting of Speech in Latin America. In: Journal of Latin American Cultural Studies, Vol. 19, No.2, August 2010.

AGAMBEN, Giorgio. State of Exception. Chicago: University of Chicago Press, 2005.

DERRIDA, Jacques. Memoirs of the Blind: The self-portrait and other ruins. Chicago: University of Chicago Press, 1993.

DERRIDA, Jacques. Specters of Marx. The State of the Debt, the Work of Mourning and the New International. New York: Routledge, 1994.

GUYER, Sara. Bucalidade. In: Revista Literatura e Sociedade, n.19, 2014.

MARCOS, Subcomandante. V Declaración de la Selva Lacandona. 19 de julho de 1998. 
MARCOS, Subcomandante. Comunicado del Comité Clandestino Revolucionario Indígena - Comandancia General del Ejército Zapatista de Liberación Nacional. 21 de dezembro de 2012.

MARCOS, Subcomandante. Entre la luz y la sombra. 26 de maio de 2014.

MARCOS, Subcomandante. Votán Zapata o 500 años de historia. 10 de abril de 1994.

NANCY, Jean-Luc. Listening. New York: Fordham University Press, 2007.

NANCY, Jean-Luc. The Birth to Presence. Redwood City: Stanford University Press, 1993.

PRECIADO, Paul B. Desprivatizar el nombre propio, deshacer la ficción individualista. Disponível em: http://www.telam.com.ar/notas/201406/67502-desprivatizar-elnombre-propio-deshacer-la-ficcion-individualista.html

RANCIÈRE, Jacques. Disagreement: Politics and Philosophy. Minneapolis: University of Minnesota Press, 1999.

SUPGALEANO. El método, la bibliografia y un Drone en las profunidades del Sureste Mexicano. 4 de maio de 2015.

WILLIAMS, Gareth. The Mexican Exception and the "Other Campaign". In: South Atlantic Quarterly 106:1, Winter 2007.

\section{$\underline{\text { 4. feminicídios }}$}

ALARCÓN, Orfa. Perra brava. Cidade do México: Planeta, 2010.

ARJONA, Arminé. Juárez, tal lleno de sol y desolado (intr. Susana Báez). Chihuahua, Chihuahua Arde Editoras, México, 2004. 
BÁEZ AYALA, Susana. De la impotencia a la creación testimonial y la denuncia social: El silencio que la voz de todas quiebra. In: Entre las duras aristas de las armas: violencia y victimización en Ciudad Juárez, coord. Patricia Ravelo Blancas, Héctor Domínguez Ruvalcaba. México: CIESAS, 2006.

BÁEZ AYALA, Susana. Los colores del amanecer: la dramaturgia social en Ciudad Juárez. In: Chihuahua hoy, 2006: visiones de su historia, economía, política y cultura / coordinación, Víctor Orozco. Chihuahua: Universidad Autónoma de Chihuahua/Instituto Chihuahuense de la Cultura, 2006.

BÁEZ AYALA, Susana. Re/presentación en el discurso poético de la frontera, el desierto y el cuerpo feminino (2001-2004). In: Nóesis. Revista de Ciencias Sociales y Humanidades, vol. 15, núm. 28, julio-diciembre, 2005.

BOLAÑO, Roberto. 2666. Barcelona: Anagrama, 2010.

BOURRIAUD, Nicolas. Estética Relacional. São Paulo: Martins Fontes, 2009.

BUTLER, Judith. Bodies that matter: on the discursive limits of "sex". Nova lorque: Routledge, 1993.

CABRERA, Patricia; CANDIA, Adriana; DE LA MORA, Guadalupe; MARTÍNEZ, Josefina; ORTíZ, Ramona; RHORY, Benítez; VELÁZQUEZ, Isabel. El silencio que la voz de todas quiebra. Mujeres y víctimas de Ciudad Juárez. Ediciones de Azar-Instituto de Estudios Chicanos de la Universidad Estatal de Nuevo México - UACJ, Chihuahua, 1999.

DE LA ROSA, Perla. Antígona: las voces que incendian el desierto. In: Cinco Dramaturgos Chihuahuenses, (coord. Guadalupe de la Mora. Ciudad Juárez, México: Fondo Municipal Editorial Revolcente, 2005.

DRIVER, Alice. More or Less Dead: Femicide, Haunting, and the Ethics of Representation ins Mexico. Tucson: The University of Arizona Press, 2015. 
FRANCO, Jean. Cruel Modernity. Durham: Duke University Press, 2013.

HUERTA David, Velia Rangel, Belinda Flores-Shinshillas y Nakarowari Leal Ortiz. Poesía, In: Metapolítica, Las muertas de Juárez, Centro de Estudios de Política Comparada, Editorial Jus, México D. F., 2003.

GASPAR DE ALBA, Alicia. Sangre en el desierto: las muertas de Juárez. Houston: Arte Público Press, 2008.

LAGARDE, Marcela. Del femicidio al feminicidio. In: Desde el jardín de Freud: revista de psicoanálisis. Número 6, 2006.

MONÁRREZ FRAGOSO, Julia Estela e TABUENCA CÓRDOBA, María Socorro (coords). Bordeando la violencia contra las mujeres en la frontera norte de México. México, El Colegio de la Frontera Norte/Miguel Ángel Porrúa, 2007.

MONÁRREZ FRAGOSO, Julia Estela. La cultura del feminicídio en Ciudad Juárez, 19931999. Revista Frontera Norte, vol 12, 2000.

MONÁRREZ FRAGOSO, Julia Estela. Las diversas representaciones del feminicidio y los asesinatos de mujeres en Ciudad Juárez, 1993-2005. In: Violencia contras las mujeres e inseguridad ciudadana en Ciudad Juárez. Ed. Luis Cervera Gómez, César Fuentes Flores e Rodolfo Rubio Salas. México: El Colef/Miguel Ángel Porrúa, 2010.

MONÁRREZ FRAGOSO, Julia Estela. Trama de una injusticia. Feminicidio sexual y sistemático en Ciudad Juárez. México: El Colef/Miguel Ángel Porrúa, 2009.

RIVERA GARZA, Cristina. La muerte me da. Tusquets: Cidade do México, 2008.

RODRÍGUEZ, Sérgio González. The Femicide Machine. Los Angeles: Semiotext(e), 2012. 
ROJAS, Juan Armando y Jennifer Rathbun (selec. y pról.). Canto a una ciudad en el desierto. Encuentro de Poetas en Ciudad Juárez (1998-2002). Antología. (Presentación Carmen Amato). México, La cuadrilla de la Langosta, Conaculta, Ichicult, Pacmyc Chihuahua, Gobierno del Estado de Chihuahua, 2004.

SEGATO, Rita Laura. La escritura en el cuerpo de las mujeres asesinadas en Ciudad Juárez. Buenos Aires: Tinta Limón, 2013.

SOLís, Micaela. Elegía en el desierto. In memoriam. Ciudad Juárez, Chihuahua, Universidad Autónoma de Ciudad Juárez, 2004.

VALENCIA, Sayak. Capitalismo Gore. Barcelona/Cidade do México: Melusina, 2010.

\section{5. animais}

BARTHES, Roland. A câmara clara: notas sobre a fotografia. Rio de Janeiro: Editora Nova Fronteira, 1984.

BARTHES, Roland. Fragmentos de um discurso amoroso. São Paulo: Martins Fontes, 2003.

BATESON, Gregory. A Theory of Play and Fantasy. In: Steps to an Ecology of Mind Collected Essays in Anthropology, Psychiatry, Evolution and Epistemology. Northvale: Jason Aronson Inc., 1987.

BATESON, Gregory. Double Bind, 1969. In: Steps to an Ecology of Mind - Collected Essays in Anthropology, Psychiatry, Evolution and Epistemology. Northvale: Jason Aronson Inc, 1987.

BENJAMIN, Walter. Sobre a linguagem em geral e a linguagem dos homens. In: Escritos sobre mitos e linguagem. São Paulo: Editora 34, 2013. 
BENVENISTE, Émile. Problemas de linguística geral. São Paulo: Companhia Editora Nacional/Editora da Universidade de São Paulo, 1970.

BOLAÑO, Roberto. 2666. Barcelona: Anagrama, 2010.

COCCIA, Emanuele. A vida sensível. Desterro: Cultura e Barbárie, 2010

COETZEE, J.M. Elizabeth Costello. Londres: Vintage, 2004.

COETZEE, J.M. Elizabeth Costello. Tradução de José Rubens Siqueira. São Paulo: Companhia das Letras, 2004.

DELEUZE, Gilles e GUATTARI, Felix. Mil Platôs: Capitalismo e Esquizofrenia. Rio de Janeiro: Editora 34, 1997.

DE LIZARDI, José Joaquín Fernández. La victoria del perico. Publicado originalmente em Cidade do México: Imprenda de do Mariano Ontiveros, em 11 de outubro de 1923. Disponível em: http://www.iifilologicas.unam.mx/obralizardi/index.php?page=lavictoria-del-perico

DERRIDA, Jacques. And Say the Animal Responded. In: The Animal That Therefore I Am. Nova Iorque: Fordham University Press, 2008.

DERRIDA, Jacques. Dissemination. Londres: The Athlone Press, 1981.

DERRIDA, Jacques. I'm Going to Have to Wander All Alone. In: Philosophy Today, v.42, n.1, Spring 1998.

DESPRET, Vinciane. O que diriam os animais se... In: Caderno de Leituras n.45, chão da feira, 2016. 
HARAWAY, Donna. Staying with the Trouble: Making Kin in the Cthlucene. Durham: Duke University Press, 2016.

HELLER-ROAZEN, Daniel. Echolalias: On the Forgetting of Language. Nova lorque: Zone Books, 2008.

HUSTAK, Carla e MYERS, Natasha. Involutionary Momentum: Affective Ecologies and the Sciences of Plant/Insect Encounters. In: diffe re n c e s: A Journal of Feminist Cultural Studies. 23:2 (2012)

LUDUEÑA ROMANDINI, Fabián. A comunidade dos espectros. I. Antropotecnia. Desterro: Cultura e Barbárie, 2012.

MARCOS, Subcomandante. La historia del ruido y el silencio. 14 de fevereiro de 1997.

MARX, Karl. O Capital - Livro 1. São Paulo: Boitempo Editorial, 2013.

NANCY, Jean-Luc. The Intruder. In: Corpus. Nova Iorque: Fordham University Press, 2008.

PRECIADO, Paul B. Manifesto Contrassexual. São Paulo: n-1, 2014.

QUENEAU, Raymond. Zazie no metrô. São Paulo: Cosac Naify, 2009.

SCHUSTER, Aaron. A Philosophy of Tickling. In: Cabinet Magazine, 50 (Summer 2013).

SIMONDON, Gilbert. L'individuation psychique et colletive. Paris: Aubier, 1989.

UEXKÜLL, von Jacob. Dos animais e dos homens. Lisboa: Livros do Brasil, 1982. 
BENJAMIN, Walter. O Narrador - considerações sobre a obra de Nicolai Leskov. In: Magia e Técnica, Arte e Política. Obras Escolhidas I. São Paulo: Brasiliense, 1994.

BOLAÑO, Roberto. 2666. Barcelona: Anagrama, 2010.

BOLAÑO, Roberto. "Esta esperanza...". In: La universidad desconocida. Barcelona: Anagrama, 2007.

BOLAÑO, Roberto. "Textos de Joe Haldeman, J.G. Ballard..." In: La universidad desconocida. Barcelona: Anagrama, 2007.

CAPUTO, John D. Dreaming of the Innumerable. In: FEDER, Ellen; RAWLINSON, Mary C.; ZAKIN, Emily (eds). Derrida and Feminism: Recasting the Question of Woman. Nova lorque: Routledge, 1997.

CAPUTO, John D. "Teaching the event: Deconstruction, hauntology, and the scene of pedagogy". In: DUNNE, Éamonn e SEERY, Aidan (eds). The Pedagogics of Unlearning. Terra, Via Láctea: punctum books, 2016.

CÉSAR, Ana Cristina. Ela ficava olhando pela janela. In: Poética: Ana Cristina César. São Paulo: Companhia das Letras, 2013.

DELEUZE, Gilles e PARNET, Claire. "P de Professor". In: O Abecedário.

DERRIDA, Jacque. "A 'Madness' Must Watch Over Thinking". In: Points...Interviews, 1974-1994. Stanford: Stanford University Press, 1995.

DERRIDA, Jacques. "Mochlos, or The Conflict of the Faculties". In: Eyes of the University: Right to Philosphy 2. Stanford: Stanford University Press, 2004. 
DERRIDA, Jacques. Specters of Marx. The State of the Debt, the Work of Mourning and the New International. New York: Routledge, 1994.

DERRIDA, Jacques. The Principle of Reason: The University in the Eyes of its Pupils. In: Eyes of the University: Right to Philosphy 2. Stanford: Stanford University Press, 2004

DERRIDA, Jacques. The University Without Condition. In: Without Alibi. Stanford: Stanford University Press, 2002.

DE SOUZA CAMPOS, Ernesto. História da Universidade de São Paulo. São Paulo: EDUSP, 1954.

EDELMAN, Lee. No Future: Queer Theory and the Death Drive. Durham: Duke University Press, 2004.

HEIDEGGER, Martin. The Fundamental Concepts of Metaphysics: World, Finitude, Solitude. Bloomington: Indiana University Press, 2001.

KANT, Immanuel. O conflito das faculdades. Lisboa: Edições 70, 1993.

PELLEGRINI, Ann. 'What do Children Learn at School': Necropedagogy and the Future of the Dead Child. In: Social Text, v.26, n.4 (97), Winter 2008.

PEETERS, Benoît. Derrida: A Biography. Cambridge: Polity Press, 2013.

PRECIADO, Paul B. Manifesto Contrassexual. São Paulo: n-1, 2014.

NANCY, Jean-Luc. Sexistance. In: Diacritics, v.43, n.4, 2015.

THAYER, Willy. A crise não moderna da universidade moderna: Epílogo de O conflito das faculdades. Belo Horizonte: Editora UFMG, 2002. 
VILLALOBOS-RUMINOTT, Sergio. Equivalencia neoliberal e interrupción nómica: el conflito de las facultades como contrato social. (Comunicação oral proferida na LASA 2016). Texto diponível em:

https://www.academia.edu/24791408/Equivalencia_neoliberal_e_interrupci\%C3\%B3n _n\%C3\%B3mica_el_conflicto_de_las_facultades_como_contrato_social 